\title{
Carex flava agg. (section Ceratocystis, Cyperaceae) in Poland: taxonomy, morphological variation, and soil conditions
}

\author{
Helena Więcław
}

Department of Plant Taxonomy and Phytogeography, Faculty of Biology, University of Szczecin, Wąska 13, 71-415 Szczecin, Poland, e-mail:wieclawh@univ.szczecin.pl

\begin{abstract}
Sedges of Carex flava agg., typical of moist or wet habitats, are difficult to classify because of a lack of clear-cut morphological differences between them and the existence of numerous hybrids. This monograph presents results of research conducted in 2007-2012 in various parts of Poland. The plant material consisted of 1852 living specimens of Carex flava agg., collected from 80 localities, and dried specimens from 26 herbaria and from 7 private collections. The analysis involved 45 morphological characters (34 quantitative and 11 qualitative) and 9 soil parameters. Univariate, bivariate, and multivariate statistical methods were used to process the data. The results confirm the taxonomic classification dividing the $C$. flava group into 4 species: C. flava s.s., C. lepidocarpa, C. demissa, and $C$. viridula. This classification is based on $(i)$ a high observed level of morphological separation of these taxa, resulting mostly from differences in generative characters, i.e. length of the utricle and its beak, and percentage ratio of beak length to total utricle length; (ii) integrity of the taxa at the sites where they coexist, although some intermediate forms resulting from hybridization are also present; (iii) habitat preferences of the taxa, especially the preference of $C$. lepidocarpa for calcareous sites and of $C$. demissa for slightly acidic soils. Thus in Poland the analysed taxa are morphologically well-defined and show clear ecological preferences. Continuous variation of morphological characters was observed among specimens of $C$. viridula, so it is not justifiable to distinguish its subspecies (sometimes classified even as separate species), described previously in literature. Consequently, the 2 subgroups of $C$. viridula were treated as local variants (i.e. varieties: var. viridula and var. pulchella), considering their different habitat requirements. Additionally, 5 hybrids were distinguished within $C$. flava agg.: $C . \times$ alsatica $[=C$.demissa $\times$ C.flava $], C . \times$ ruedtii $[=C$. flava $\times$ C. lepidocarpa $], C . \times$ schatzii $[=C$. lepidocarpa $\times C$. viridula $], C . \times$ subviridula $[=C$. flava $\times C$. viridula $]$, and C. demissa $\times C$. viridula; as well as 2 hybrids with $C$. hostiana as one of the parents: $C . \times$ fulva $[=C$. demissa $\times C$. hostiana $]$ and $C . \times$ leutzii $[=C$. hostiana $\times C$. lepidocarpa $]$.
\end{abstract}

Key words: Carex flava agg., section Ceratocystis, Cyperaceae, taxonomic classification, morphology, variation, soil conditions, hybrids, key to identification

\section{Contents}

1. Introduction

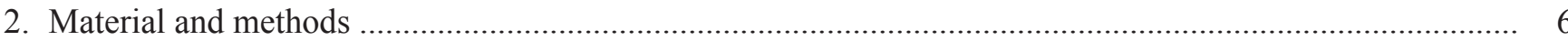

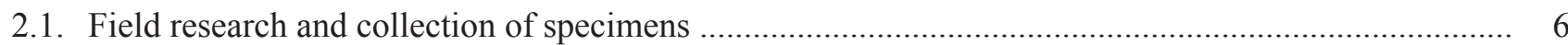

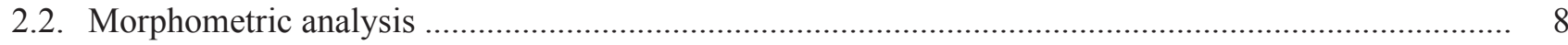

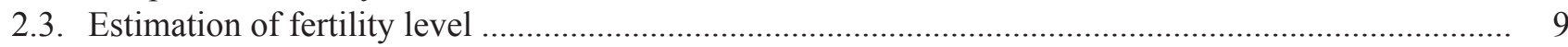

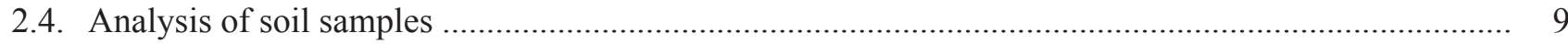

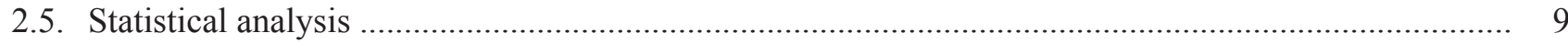

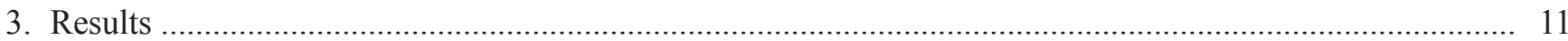

3.1. Variation in morphological characters; pair-wise correlations .................................................. 11

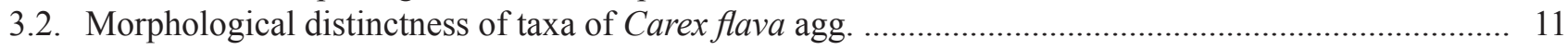

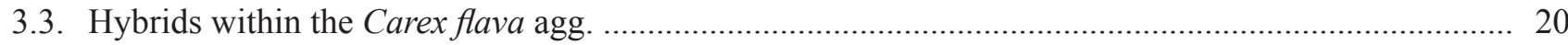


3.4. Relationships between taxa and soil parameters 23

3.5. Key to identification of taxa within the section Ceratocystis ............................................................ 24

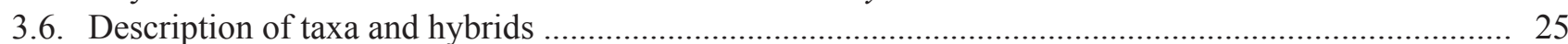

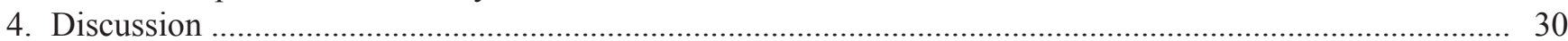

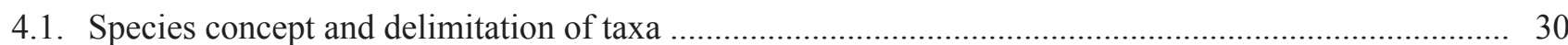

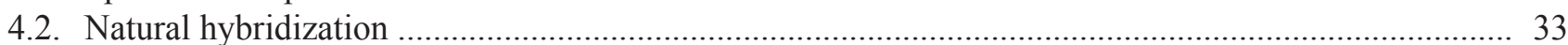

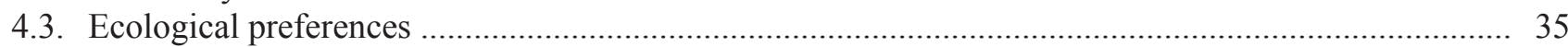

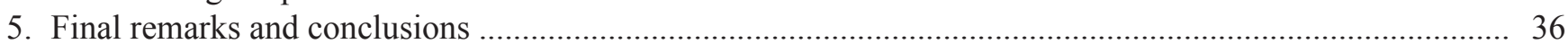

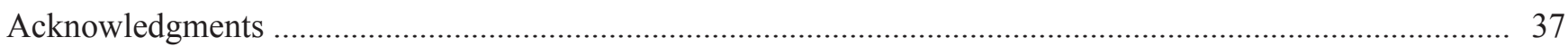

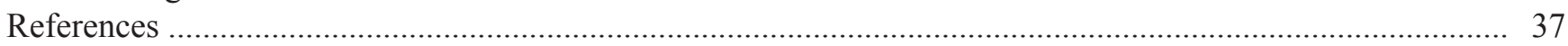

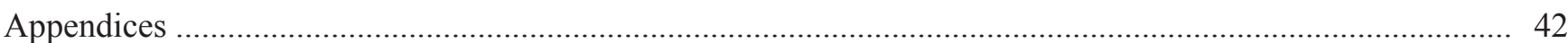

\section{Introduction}

Carex L. is one of the most species-rich genera of vascular plants, as it includes about 2000 species distributed worldwide, usually in temperate to polar regions, including tropical alpine zones (Goetghebeur 1998; Egorova 1999; Frodin 2004; Govaerts et al. 2010). Species diversity of this genus is the highest in the temperate zone of the Northern Hemisphere, especially in western Asia and North America; the number of species of this genus is much lower in warmer regions, such as southern Asia and eastern Africa (Govaerts et al. 2010; Gehrke 2011). In Europe the genus is represented by about 200 species (Chater 1980; Koopman 2011).

On the basis of inflorescence structure, Kükenthal (1909) divided the genus Carex into 4 subgenera: Carex L., Psyllophora (Degl.) Peterm. (= Primocarex Kük.), Vignea (P. Beauv. ex Lestib) Peterm., and Vigneastra (Tuck.) Kük (= Indocarex (Baill.) Kük.). His classification is still valid, but recent molecular studies indicate that the subgenus Carex is probably paraphyletic, and may in fact include species of the subgenus Vigneastra (e.g. Yen \& Olmstead 2000; Roalson et al. 2001; Hendrichs et al. 2004; Waterway et al. 2009).

Subgenus Carex, represented globally by about 1400 species of 60 sections (Egorova 1999), includes taxa that differ morphologically, especially in the sexual expression of spikes (Reznicek 1990; Molina et al. 2012). In Europe, 121 species of 24 sections have been recorded (Chater 1980). Within the subgenus Carex, the section Ceratocystis Dumort. is one of the most systematically difficult groups, because of a lack of clear discontinuities in their morphology, polymorphism, and the existence of many hybrids (Jiménez-Mejías et al. 2012a). Generally, the main morphological characteristics of the section Ceratocystis are: ovoid-ellipsoid utricles, not speckled, with a long bifid beak, obovate achenes, globose to oblong female spikes, and usually a solitary subcylindrical, sessile or pedunculate male spike (Chater 1980; Egorova 1999; Crins 2002).
The section Ceratocystis includes taxa of Carex flava agg., also referred to as the Carex flava group or complex. The group is known for its complicated pattern of morphological variation and contrasting differences in taxonomic classification (e.g. Skårman 1940; Wiinstend 1947; Palmgren 1959; Patzke \& Podlech 1960; Schmid 1983; Pykälä \& Toivonen 1994; Egorova 1999). Among European sedges, C. flava agg. is one of the most difficult complexes, with several ambiguously defined taxa. Considering the observed morphological variation, a lack of clear hiatus between taxa and frequent hybridization, delimitation of the segregates poses some difficulties. Only C. flava L. is a morphologically welldefined species, usually easily identifiable, whereas the taxonomic position of C. lepidocarpa Tausch, C. demissa Hornem., and C. viridula Michx. is still disputable (species, subspecies or varieties) (e.g. Schmid 1983; Pykälä \& Toivonen 1994; Egorova 1999; Hedrén 2002).

The C. flava group has been studied in many European countries. Beside "traditional" taxonomic descriptions (Palmgren 1946, 1959; Davies 1953a, 1953b, 1953c; Schmid 1983; Crins \& Ball 1989b; Pykälä \& Toivonen 1994), available information concerns its cytology (Davies 1955; Schmid 1982; Halkka et al. 1992), ecology (Davies 1956; Schmid 1984a, 1984b, 1986b), morphology (Havlícková 1982; Schmid 1986a; Crins \& Ball 1989a; Salo et al. 1994; Hedrén 1998; Blackstock \& Ashton 2001; Meijden \& Holverda 2006; Blackstock 2007), phenology (Vonk 1979), as well as phylogenetic (Crins \& Ball 1988), allozymatic (Hedrén \& Prentice 1996; Hedrén 1996, 2002; Blackstock 2007), and molecular studies (Jiménez-Mejías et al. 2012a).

However, despite so many studies, no consensus has been reached so far on the classification and description of taxa within this complex. Various classifications divide European sedges of the C. flava group into units of various size (Chater 1980; Egorova 1999; Hedrén 2004). The most radical approach, associated with the biological species concept (Mayr 1957), presented by Sell (1996), recognizes only a single species, C. flava 
s.l. At the other extreme, usually related to the ecological species concept (van Valen 1976), 8 species are distinguished [C. Alava, C. lepidocarpa, C. jemtlandica Palmgr., C. demissa, C. viridula, C. pulchella (Lönnr.) Lindm. (= C. scandinavica E. W. Davies), C. bergrothii Palmgr. and C. nevadensis Boiss \& Reuter] (e.g. Davies 1953a, c; Palmgren 1959; Chater 1980; Egorova 1999). A recently described new species, Carex derelicta Štepánková, found at only one site in the Karkonosze Mts. in the Czech Republic, is probably of hybrid origin (Štepánková 2008). It was earlier described as $C$. oederi Retz. subsp. pseudoscandinavica (Holub et al. 1979; Havlícková 1982) or C. viridula Michx. subsp. pseudoscandinavica (Holub 1999; Grulich \& Řepka 2002). The taxon is morphologically similar to $C$. viridula var. pulchella (Štepánková 2008), and in my opinion requires further research, with the use of molecular methods. The taxonomic status is also unclear in the case of C. castroviejoi Luceño \& Jim.-Mejías, which was first described from Greece (Jiménez-Mejías \& Luceño 2009), and recently found in Albania (JiménezMejías et al. 2012b). According to Jiménez-Mejías \& Luceño (2009), the taxon has deflexed utricles with bent and smooth beaks, and a widely fusiform male spike, at least $3 \mathrm{~mm}$ wide.

Classifications in some European floras (e.g. Rich 1998; Jermy et al. 2007) and in the World Checklist of Cyperaceae (Govaerts \& Simpson 2007) are based on the taxonomic concept of Schmid (1983), who delimited taxa of the $C$. flava complex on the basis of fertility level of hybrids. Schmid (1983) reduced the number of species within the C. flava group to 2, namely C. flava s.s. and C. viridula s.1., including C. lepidocarpa, C. demissa, C. oederi Retz., and C. nevadensis; he classified them, as C. viridula subsp. brachyrrhyncha (Tausch) B. Schmid, C. viridula subsp. oedocarpa (Andersson) B. Schmid, C. viridula Michx. subsp. viridula (var. viridula, var. bergrothii, and var. pulchella), and C. viridula subsp. nevadensis (Boiss. \& Reuter) B. Schmid, respectively. Besides, he showed that $C$. oederi is conspecific with C. viridula (Schmid 1983). On the basis of Swiss sedge populations, he observed morphological variation in specimens of C. flava s.s. along the topographic gradient and reported 2 topoclines: C. flava var. flava and var. alpina Kneuck. (Schmid 1983). Similar approaches to taxonomic classification of the $C$. flava group are presented by Crins \& Ball (1989b) and Bruederle \& Jensen (1991).

The classification proposed by Schmid (1983) has not been accepted by many scientists. In Scandinavia, where the pattern of variation of taxa of the C. flava complex seems to be most complicated, C. lepidocarpa, C. demissa, and C. viridula are still regarded as separate species (Palmgren 1959; Hedrén 1990, 1994, 1996, 1998, 2002, 2004; Pykälä \& Toivonen 1994; Hedrén \& Prentice 1996). This taxonomic approach is popular also among researchers in the Iberian Peninsula (Luceño \& Castroviejo 1993; Luceño \& Jiménez-Mejías 2007; Jiménez-Mejías et al. 2012a) and in Russia (Egorova 1999). Morphological and genetic analyses conducted in the British Isles also confirm that these taxa should be classified as species (Blackstock 2007).

With regard to taxa of the $C$. flava group, various intraspecific categories are used. Within C. lepidocarpa, 3 subspecies are distinguished: $C$. lepidocarpa Tausch subsp. lepidocarpa, subsp. jemtlandica Palmgr., and subsp. scotica E. W. Davies (Koopman 2011). C. lepidocarpa subsp. jemtlandica is found in Scandinavia, Russia, and Estonia (Hedrén 1990, 1996, 2002; Pykälä \& Toivonen 1994) and in the British Isles (Blackstock 2007), while C. lepidocarpa subsp. scotica is reported from Scotland, Wales, and northern England (Davies 1953b). Within C. demissa, 3 subspecies are distinguished: C. demissa Hornem. subsp. demissa, C. demissa Hornem. subsp. cedercreutzii (Fagerström) Jac. Koopman, recorded on the Azores and Madeira (Fagerström 1967; Koopman 2011), and subsp. iranica Kukkonen, growing in Iran and Afghanistan (Kukkonen 1984).

The most variable morphologically is $C$. viridula, forming small, isolated populations regarded as varieties [C. viridula Michx. var. viridula, $C$. viridula var. pulchella (Lönnr.) B. Schmid, and C. viridula var. bergrothii (Palmgr.) B. Schmid] (Pykälä \& Toivonen 1994) or subspecies [C. viridula Michx. subsp. viridula, C. viridula Michx. subsp. bergrothii (Palmgr.) Tzvelev, and C. viridula Michx. subsp. pulchella (Lönnr.) Malyschev] (Blackstock 2007). In addition, the nomenclature of those taxa in Europe is still subject to some confusion, e.g. Hedrén (2002) is of the opinion that the name $C$. oederi s.l. rather than $C$. viridula should be used, whereas Egorova (1999) uses the names $C$. viridula and $C$. serotina, to denote separate species.

In Spain in the Sierra Nevada Mts, C. nevadensis is found, but its taxonomic position is still discussed (Jiménez-Mejías et al. 2012a). Schmid (1983) treated it as a subspecies within $C$. viridula s.1., while Crins \& Ball (1989b) classified it as a variety, C. viridula var. nevadensis (Boiss. \& Reuter) Crins. By contrast, Luceño (1999) regarded it as a subspecies of C. lepidocarpa and named it C. lepidocarpa subsp. nevadensis (Boiss. \& Reuter) Luceño.

In North America, C. demissa, C. lepidocarpa, and C. viridula are fused into a single species, as suggested by Schmid (1983). Additionally, 3 species included in the $C$. flava group are endemic to that region: $C$. lutea LeBlond, C. cryptolepis Mack., and C. viridistellata Derieg, Weil, Reznicek \& Bruederle (Crins \& Ball 1989a, 1989b; LeBlond et al. 1994; Crins 2002; Derieg et al. 2008, 2013).

The pattern of variation observed in C. flava agg. is complicated by the appearance of hybrids in mixed 
populations. They are morphologically intermediate between the parental forms or are more similar to one of them (Wallace et al. 1975; Kiffe 1998; Więclaw \& Wilhelm 2014). They are usually completely sterile although some partly fertile hybrids and introgression have been reported (Schmid 1982).

Taxa of the C. flava complex are usually found on moist or wet sites: meadows, marshes, fens (especially in groundwater seepage areas), other types of mires, shores of lakes, seas, ponds, ditches, roadsides, rarely forests (Davies 1956; Schmid 1984a, 1984b).

In Poland the $C$. flava group was not studied in detail before. Research conducted in Poland covered sedges of various subgenera and sections, e.g. of the sections Heleoglochin Dumort. (= Paniculatae (Carey) Christ.) (Szczepanik-Janyszek 2003), Phacocystis Dumort. (= Acutae (Carey) Christ.) (Klimko 1981), Phaestoglochin Dumort. (= Muehlenbergianae Tuckerm. ex Kük.) (Szczepanik-Janyszek 2001; Janyszek \& Jagodziński 2009), Vulpinae (Carey) Christ. (Szczepanik-Janyszek \& Woźnica 2001), or concerned the taxonomy, distribution, and ecology of selected species, e.g. C. atherodes Spreng. (e.g. Krawiecowa \& Kuczyńska 1959; Ćwikliński 1986; Więcław \& Ciaciura 2005), C. arenaria L. and C. ligerica J. Gay (Urbaniak 1992, 1998; Urbaniak et al. 2000), C. buxbaumii Wahlenb. (Sotek 2006), C. cespitosa L. (Brzosko 1999, 2001), C. curvata Knaf (Szelag 2002), C. extensa Gooden. (Bosiacka \& Więcław 2012), C. hartmanii Cajander (Sotek 2008), C. loliacea L. and C. disperma Dewey (Pawlikowski 2010), C. pallens (Fristedt) Harmaja (Szelag 2001), C. pediformis (Towpasz 1969), C. posnaniensis (Ceynowa 1969), C. pseudobrizoides (Żukowski \& Lembicz 2000), C. repens Bellardi (Lembicz et al. 2010), or C. secalina Wahlenb. (Żukowski et al. 2005; Lembicz et al. 2006).

According to Mirek et al. (2002), in Poland 97 species of the genus Carex are found, including 5 species of the C. flava complex. In the Polish flora published in 1919 (Raciborski 1919), only 3 species of this group were listed: C. flava, C. lepidocarpa, and C. oederi. The fourth species, C. demissa was first recorded in Poland in 1965 (Jasiewicz 1965), whereas C. viridula var. pulchella (= C. scandinavica), in 1968 (Zając 1968),

In this study of taxa of the C. flava group, the following hypotheses were formulated: $(i)$ application of the phenetic species concept and numerical analysis make it possible to identify borders of morphological variation between taxa of the C. flava complex from Polish populations; (ii) the taxonomic approach that fuses $C$. lepidocarpa, C. viridula, and C. demissa into one species disagrees with the clear morphological and habitat variation of these taxa in Poland; (iii) in Poland there are at least 4 well-defined taxa of the C. flava group; (iv) in the populations where 2-3 of the studied taxa grow sympatrically, hybrids with various levels of fertility appear; ( $v$ ) plants included in C. flava agg. prefer moist habitats and are usually found on more or less alkaline soils.

To verify these hypotheses, the following research tasks were performed: (1) determination of the number and rank of taxa found in Poland, (2) determination of the level of their morphological variation and identification of most useful diagnostic features, (3) construction of a key to identification, and (4) measurement of soil parameters.

\section{Material and methods}

\subsection{Field research and collection of specimens}

Field research was conducted in 2007-2012 in the following macroregions of Poland (Kondracki 2002): Koszalin Coast District (Pobrzeże Koszalińskie), Gdańsk Coast Disctrict (Pobrzeże Gdańskie), Szczecin Coast District (Pobrzeże Szczecińskie), West Pomeranian Lakeland (Pojezierze Zachodniopomorskie), South Pomeranian Lakeland (Pojezierze Południowopomorskie), Chełmno-Dobrzyń Lakeland (Pojezierze Chełmińsko-Dobrzyńskie), Masurian Lakeland (Pojezierze Mazurskie), Lithuanian Lakeland (Pojezierze Litewskie), Milicz-Głogów Depression (Obniżenie Milicko-Głogowskie), Przedbórz Upland (Wyżyna Przedborska), Woźniki-Wieluń Upland (Wyżyna Woźnicko-Wieluńska), Nida Basin (Niecka Nidziańska), Western and Eastern Sudetes, and Eastern Beskid Mts (Appendix 1). From 80 localities, 1852 fruiting specimens were collected in total. At 14 of the 80 sites, local populations were mixed, composed of 2 well-defined taxa of the $C$. flava group, whereas at 4 localities, 3 taxa coexisted (Appendix 1). The investigated sites were at least $200 \mathrm{~m}$ apart and differed in soil conditions. Sedges were collected from various types of habitats, representing a complete ecological spectrum of these taxa, i.e. from typical, poor, and calcareous fens, moist meadows, marshes, partly overgrown ponds, ditches, roadsides, salt-marshes, peaty and sandy edges of lakes, depressions between dunes, thickets, and alder forests. From individual sites, 2-82 specimens were collected, depending on the local abundance of sedges and their morphological variation, suggesting coexistence of several species and hybrids on the same site. To minimize the probability of collecting species of the same clone, the sampled plants were about 3-6 $\mathrm{m}$ apart. For comparison, sedges of the C. flava group were collected also during field research in 2013 in Switzerland and the Netherlands. All the specimens have been deposited in the herbarium of Szczecin University (SZUB).

In this study, also dried specimens from Polish herbaria were taken into account (BIL, BNPH, BSG, BYDG, DRAPN, KRA, KRAM, KRAB, KTC, KTU, 
Table 1. Morphological characters used for description of taxa of the Carex flava group (those used in statistical analyses are marked with asterisks)

\begin{tabular}{|c|c|c|}
\hline No. & Character & Abbr. \\
\hline 1. & Culm height $(\mathrm{cm})^{*}$ & $\mathrm{CH}$ \\
\hline 2. & Culm width above uppermost cauline leaf (mm) & $\mathrm{CW}$ \\
\hline 3. & Cauline leaf width $(\mathrm{cm})^{*}$ & CLW \\
\hline 4. & Cauline leaf length $(\mathrm{cm})^{*}$ & CLL \\
\hline 5. & Cauline leaf sheath length $(\mathrm{cm})$ & CLSL \\
\hline 6. & Basal leaf width $(\mathrm{cm})$ & BLW \\
\hline 7. & Basal leaf length $(\mathrm{cm})$ & BLL \\
\hline 8. & $\begin{array}{l}\text { Ratio of culm height to leaf length* ( } 1 \text { - leaves up to half as long as culm, } 2 \text { - leaves about } 3 / 4 \\
\text { as long as culm, } 3 \text { - leaves as long as culm, } 4 \text { - leaves longer than culm) }\end{array}$ & $\mathrm{C} / \mathrm{L}$ \\
\hline 9. & Ligule length $(\mathrm{mm})$ & LL \\
\hline 10. & Inflorescence length $(\mathrm{cm})^{*}$ & IL \\
\hline 11. & Male spike length $(\mathrm{cm})^{*}$ & MSL \\
\hline 12. & Male spike width $(\mathrm{cm})^{*}$ & MSW \\
\hline 13. & Male spike peduncle length $(\mathrm{cm})^{*}$ & MPL \\
\hline 14. & Number of female spikes* & NFS \\
\hline 15. & Distance between 2 uppermost female spikes $(\mathrm{cm})^{*}$ & DUFS \\
\hline 16. & Distance between 2 lowest female spikes $(\mathrm{cm})^{*}$ & DLFS \\
\hline 17. & Lowest female spike length $(\mathrm{cm})^{*}$ & LFSL \\
\hline 18. & Lowest female spike width $(\mathrm{cm})^{*}$ & LFSW \\
\hline 19. & Lowest female spike peduncle length $(\mathrm{cm})^{*}$ & LPL \\
\hline 20. & Lowest female spike bract length $(\mathrm{cm})^{*}$ & LBL \\
\hline 21. & Lowest female spike bract width $(\mathrm{cm})^{*}$ & LBW \\
\hline 22. & Lowest female spike bract sheath length $(\mathrm{cm})^{*}$ & LBSL \\
\hline 23. & $\begin{array}{l}\text { Ratio of lowest female spike bract length to inflorescence length* ( } 1 \text { - bract shorter } \\
\text { than inflorescence, } 2 \text { - bract as long as inflorescence, } 3 \text { - bract up to twice as long as } \\
\text { inflorescence, } 4 \text { - bract more than twice as long as inflorescence) }\end{array}$ & $\mathrm{B} / \mathrm{I}$ \\
\hline 24. & Uppermost female spike length $(\mathrm{cm})^{*}$ & UFSL \\
\hline 25. & Uppermost female spike width $(\mathrm{cm})^{*}$ & UFSW \\
\hline 26. & Second female spike bract length $(\mathrm{cm})^{*}$ & SBL \\
\hline 27. & Second female spike bract width $(\mathrm{cm})^{*}$ & SBW \\
\hline 28. & Second female spike bract sheath length $(\mathrm{cm})$ & SBSL \\
\hline 29. & Utricle length $(\mathrm{mm})^{*}$ & UL \\
\hline 30. & Utricle width (mm) & UW \\
\hline 31. & Utricle colour & $\mathrm{UC}$ \\
\hline 32. & Utricle beak length $(\mathrm{mm})^{*}$ & UBL \\
\hline 33. & Beak shape ( 1 - straight, 2 - curved) & BSH \\
\hline 34. & Beak surface ( 1 - numerous bristles, 2 - sparse bristles, 3 - smooth) & BSU \\
\hline 35. & Ratio of beak length to utricle length (\%)* & $\mathrm{B} / \mathrm{U}$ \\
\hline 36. & Presence of fruits in utricles ( 1 - absent, 2 - present $)$ & $\mathrm{PF}$ \\
\hline 37. & $\begin{array}{l}\text { Ratio of fruit size to utricle size ( } 1 \text { - fruit filling } 1 / 3 \text { to } 1 / 2 \text { of utricle body, } 2 \text { - fruit filling } 1 / 2 \text { of } \\
\text { utricle body, } 3 \text { - fruit filling } 1 / 2 \text { to } 2 / 3 \text { of utricle body, } 4 \text { - fruit filling } 2 / 3 \text { to } 3 / 4 \text { of utricle body, } 5 \\
\text { - fruit completely filling utricle body) }\end{array}$ & $\mathrm{F} / \mathrm{U}$ \\
\hline 38. & Female glume length $(\mathrm{mm}) *$ & FGL \\
\hline 39. & Female glume width $(\mathrm{mm})^{*}$ & FGW \\
\hline 40. & Female glume colour & FGC \\
\hline 41. & Female glume shape & FGS \\
\hline 42. & Male glume length $(\mathrm{mm})^{*}$ & MGL \\
\hline 43. & Male glume width $(\mathrm{mm})^{*}$ & MGW \\
\hline 44. & Male glume colour & MGC \\
\hline 45. & Male glume shape & MGS \\
\hline
\end{tabular}

LBLM, LOD, OLTC, OPOL, POZ, PUMA, TRN, SLTC, SPNH, SZCZ, SZUB, UGDA, WA, WRSL, WSRP, ZAMU; abbreviations of the names of herbaria follow Mirek et al. 1997), and from collections of Dr hab. B. Babczyńska-Sendek, Dr hab. K. Oklejewicz, Dr A. Błońska, P. Kalinowski, MSc, J. Koopman, MSc, P. Kobierski, MSc, and R. Ryś, MSc. The analysed material included also C. flava agg. from herbaria in Berlin 
Table 2. Variation of morphological characters of taxa of the Carex flava group

\begin{tabular}{|c|c|c|c|c|c|c|c|c|c|c|c|c|c|c|c|c|c|c|c|c|}
\hline \multirow{2}{*}{ Character } & \multicolumn{5}{|c|}{ C. flava s.s. } & \multicolumn{5}{|c|}{ C. lepidocarpa } & \multicolumn{5}{|c|}{ C. demissa } & \multicolumn{5}{|c|}{ C. viridula var. viridula } \\
\hline & $x$ & $\min$ & $\max$ & SD & $V$ & $x$ & $\min$ & $\max$ & SD & $V$ & $x$ & $\min$ & $\max$ & $\mathrm{SD}$ & V & $x$ & $\min$ & $\max$ & SD & $V$ \\
\hline $\mathrm{CH}$ & 40.0 & 12.5 & 67.3 & 12.56 & 31 & 52.4 & 20.3 & 84.2 & 10.84 & 21 & 25.3 & 6.1 & 56.5 & 9.33 & 37 & 17.7 & 2.9 & 44.9 & 9.30 & 52 \\
\hline CLW & 00.3 & 00.2 & 0.5 & 0.07 & 20 & 0.3 & 0.2 & 0.4 & 0.04 & 17 & 0.3 & 0.2 & 0.4 & 0.04 & 16 & 0.2 & 0.1 & 0.3 & 0.03 & 14 \\
\hline CLL & 17.6 & 07.9 & 29.1 & 3.98 & 23 & 11.9 & 5.5 & 22.4 & 3.35 & 28 & 8.6 & 2.9 & 17.8 & 3.07 & 36 & 10.4 & 3.1 & 23.1 & 3.85 & 37 \\
\hline $\mathrm{C} / \mathrm{L}$ & 03.0 & $1 .$. & 4.0 & 0.88 & 36 & 1.0 & 1.0 & 3.0 & 0.53 & 38 & 2.0 & 1.0 & 4.0 & 0.60 & 39 & 3.0 & 1.0 & 4.0 & 0.97 & 34 \\
\hline IL & 4.2 & 1.5 & 20.1 & 2.74 & 66 & 6.5 & 2.6 & 23.4 & 3.47 & 53 & 8.8 & 1.6 & 33.4 & 6.35 & 72 & 3.9 & 1.1 & 16.1 & 2.47 & 62 \\
\hline MSL & 1.5 & 0.8 & 2.3 & 0.29 & 20 & 1.8 & 1.0 & 3.1 & 0.39 & 21 & 1.4 & 0.8 & 2.2 & 0.30 & 21 & 1.1 & 0.4 & 2.0 & 0.41 & 37 \\
\hline MSW & 0.2 & 0.1 & 0.2 & 0.02 & 15 & 0.2 & 0.1 & 0.2 & 0.02 & 12 & 0.2 & 0.1 & 0.2 & 0.02 & 13 & 0.2 & 0.1 & 0.2 & 0.03 & 17 \\
\hline MPL & 0.2 & 0.0 & 1.4 & 0.27 & 125 & 1.7 & 0.2 & 6.0 & 1.14 & 66 & 0.5 & 0.0 & 2.1 & 0.34 & 69 & 0.2 & 0.0 & 2.1 & 0.36 & 164 \\
\hline NFS & 3.0 & 2.0 & 5.0 & 0,61 & 22 & 2.0 & 1.0 & 4.0 & 0,65 & 33 & 3.0 & 2.0 & 5.0 & 0,61 & 19 & 4.0 & 2.0 & 7.0 & 0.98 & 28 \\
\hline DUFS & 0.8 & 0.0 & 3.5 & 0.78 & 101 & 2.3 & 0.2 & 13.9 & 1.97 & 84 & 0.7 & 0.1 & 6.9 & 0.51 & 78 & 0.4 & 0.0 & 7.0 & 0.54 & 134 \\
\hline DLFS & 2.0 & 0.1 & 16.2 & 2.86 & 143 & 5.3 & 1.0 & 19.9 & 5.02 & 94 & 6.3 & 0.4 & 27.3 & 5.88 & 93 & 1.8 & 0.0 & 11.6 & 2.08 & 117 \\
\hline LFSL & 1.3 & 1.0 & 2.2 & 0.19 & 14 & 1.3 & 0.8 & 2.2 & 0.24 & 18 & 1.1 & 0.7 & 1.6 & 0.19 & 18 & 0.9 & 0.6 & 1.4 & 0.17 & 19 \\
\hline LFSW & 0.9 & 0.7 & 1.1 & 0.08 & 8 & 0.8 & 0.7 & 1.0 & 0.07 & 9 & 0.7 & 0.4 & 0.9 & 0.08 & 11 & 0.6 & 0.4 & 0.8 & 0.07 & 11 \\
\hline LPL & 0.5 & 0.0 & 3.2 & 0.53 & 111 & 0.4 & 0.0 & 3.3 & 0.67 & 155 & 0.4 & 0.0 & 2.1 & 0.35 & 95 & 0.2 & 0.0 & 3.2 & 0.40 & 192 \\
\hline LBL & 12.0 & 3.2 & 26.5 & 3.66 & 31 & 6.3 & 0.6 & 17.7 & 2.96 & 47 & 8.3 & 2.4 & 18.8 & 3.01 & 36 & 8.0 & 2.8 & 21.7 & 3.33 & 42 \\
\hline LBW & 0.3 & 0.2 & 0.5 & 0.06 & 23 & 0.2 & 0.0 & 0.3 & 0.05 & 35 & 0.2 & 0.2 & 0.4 & 0.04 & 15 & 0.2 & 0.1 & 0.3 & 0.03 & 14 \\
\hline LBSL & 0.5 & 0.1 & 4.4 & 0.57 & 112 & 0.6 & 0.1 & 4.2 & 0.62 & 104 & 0.9 & 0.1 & 4.4 & 0.68 & 72 & 0.6 & 0.0 & 9.2 & 0.73 & 124 \\
\hline $\mathrm{B} / \mathrm{I}$ & 4.0 & 3.0 & 4.0 & 0.34 & 9 & 2.0 & 1.0 & 3.0 & 0.84 & 41 & 2.0 & 1.0 & 4.0 & 1.07 & 49 & 3.0 & 1.0 & 4.0 & 0.66 & 19 \\
\hline UFSL & 1.2 & 0.9 & 1.7 & 0.13 & 12 & 1.2 & 0.8 & 1.9 & 0.21 & 18 & 0.9 & 0.6 & 1.3 & 0.14 & 15 & 0.7 & 0.4 & 1.3 & 0.14 & 20 \\
\hline UFSW & 0.9 & 0.8 & 1.1 & 0.07 & 8 & 0.8 & 0.7 & 1.0 & 0.07 & 9 & 0.7 & 0.5 & 0.9 & 0.07 & 10 & 0.6 & 0.4 & 0.8 & 0.07 & 12 \\
\hline SBL & 5.3 & 1.3 & 10.9 & 1.91 & 36 & 2.1 & 0.4 & 7.5 & 1.54 & 75 & 4.3 & 0.8 & 11.9 & 1.74 & 41 & 2.9 & 0.0 & 9.8 & 1.45 & 50 \\
\hline SBW & 0.1 & 0.1 & 0.3 & 0.04 & 24 & 0.1 & 0.0 & 0.1 & 0.03 & 59 & 0.2 & 0.0 & 0.3 & 0.04 & 26 & 0.1 & 0.0 & 0.2 & 0.04 & 43 \\
\hline UL & 4.8 & 3.9 & 6.2 & 0.44 & 9 & 4.0 & 3.5 & 4.8 & 0.30 & 7 & 3.6 & 2.9 & 4.3 & 0.35 & 10 & 2.9 & 2.1 & 4.1 & 0.34 & 12 \\
\hline UBL & 2.2 & 1.8 & 2.8 & 0.21 & 10 & 1.5 & 1.1 & 1.8 & 0.14 & 10 & 1.3 & 0.9 & 1.8 & 0.17 & 12 & 0.9 & 0.6 & 1.3 & 0.14 & 15 \\
\hline $\mathrm{B} / \mathrm{U}$ & 46.0 & 41.0 & 50.0 & 2.07 & 5 & 36.0 & 30.0 & 45.0 & 2.74 & 8 & 41.0 & 35.0 & 45.0 & 2.44 & 6 & 31.0 & 23.0 & 36.0 & 2.63 & 8 \\
\hline FGL & 3.0 & 2.3 & 4.2 & 0.39 & 13 & 2.5 & 2.1 & 3.3 & 0.22 & 9 & 2.6 & 2.0 & 3.5 & 0.33 & 13 & 2.1 & 1.5 & 3.0 & 0.28 & 13 \\
\hline FGW & 1.5 & 1.2 & 1.8 & 0.12 & 8 & 1.5 & 1.2 & 1.8 & 0.11 & 8 & 1.5 & 1.1 & 2.0 & 0.13 & 9 & 1.3 & 1.0 & 1.7 & 0.15 & 11 \\
\hline MGL & 3.6 & 2.9 & 4.4 & 0.30 & 8 & 3.5 & 2.9 & 4.2 & 0.21 & 6 & 3.9 & 3.1 & 5.2 & 0.42 & 11 & 3.2 & 2.4 & 4.2 & 0.32 & 10 \\
\hline MGW & 1.5 & 1.1 & 1.9 & 0.14 & 9 & 1.6 & 1.3 & 2.1 & 0.12 & 8 & 1.6 & 1.2 & 2.0 & 0.13 & 8 & 1.4 & 1.2 & 2.1 & 0.13 & 9 \\
\hline
\end{tabular}

Explanations: $x$ - arithmetic mean, min and max - minimum and maximum values, $\mathrm{SD}$ - standard deviation, $V$ - coefficient of variation for individual taxa, $V_{0}-$ coefficient of variation for all taxa analysed jointly. Characters abbreviated as in Table 1

(B) and Leiden (L). In total, identification of over 3500 herbarium specimens was verified and 1500 herbarium specimens were measured.

Additionally, herbarium specimens of $C$. hostiana were verified, as it also belongs to the section Ceratocystis and often forms hybrids with taxa of the C. flava complex (Kiffe 2001; Więcław \& Koopman 2013). C. hostiana, as the only species of this section, has welldeveloped, short rhizomes and narrowly cylindrical, remote, female spikes usually on peduncles, and dark brown glumes (Chater 1980; Crins \& Ball 1987). The collected information was used to construct a key to identification of sedges of the section Ceratocystis (Appendix 2).

\subsection{Morphometric analysis}

The operational taxonomic unit (OTU) in this study was a fresh or herbarium specimen described on the basis of 45 morphological characters (34 quantitative and 11 qualitative) (Table 1). All the analysed characters were used in species descriptions and for constructing a key to their identification. In statistical analyses, the morphological database was limited to 29 characters (marked with asterisks in Table 1), because of ( $i$ ) difficulties with measurement of some characters in herbarium specimens and relating them to measurements of fresh specimens; (ii) low taxonomic value of some characters, e.g. glume colour and shape were similar in most of the compared taxa; (iii) specificity of some features to C. flava, which is the best-defined species of the analysed aggregate, e.g. ligule length; (iv) lack of some data, e.g. dimensions of basal leaves in herbarium specimens.

Culm height, leaf length, bract length, and inflorescence length were measured with a ruler to the nearest $0.1 \mathrm{~cm}$. All the other vegetative characters were measured with Vernier callipers to the nearest $0.05 \mathrm{~mm}$. Dimensions of utricles, glumes, and spikes, as well as peduncle length and ligule length were measured 


\begin{tabular}{rrrrrr}
\multicolumn{7}{c}{ C. viridula } & var. pulchella & & \multicolumn{1}{c}{$V_{0}$} \\
\cline { 1 - 4 }$x$ & min & max & SD & \multicolumn{1}{c}{$V$} & \multicolumn{1}{c}{$\%$} \\
\hline 5.9 & 2.8 & 11.3 & 3.05 & 52 & 56 \\
0.2 & 0.1 & 0.2 & 0.02 & 13 & 22 \\
4.3 & 2.6 & 5.9 & 1.18 & 28 & 42 \\
3.0 & 3.0 & 4.0 & 0.50 & 15 & 48 \\
1.7 & 0.7 & 2.8 & 0.62 & 37 & 80 \\
0.9 & 0.5 & 1.4 & 0.36 & 42 & 32 \\
0.2 & 0.1 & 0.2 & 0.03 & 21 & 16 \\
0.1 & 0.0 & 0.3 & 0.11 & 103 & 145 \\
2.0 & 2.0 & 3.0 & 0.50 & 21 & 32 \\
0.4 & 0.2 & 0.9 & 0.23 & 60 & 135 \\
0.4 & 0.3 & 0.4 & 0.03 & 8 & 121 \\
0.7 & 0.6 & 0.8 & 0.08 & 12 & 24 \\
0.5 & 0.5 & 0.5 & 0.03 & 5 & 20 \\
0.0 & 0.0 & 0.3 & 0.09 & 188 & 142 \\
3.0 & 1.8 & 4.5 & 1.00 & 33 & 44 \\
0.2 & 0.1 & 0.2 & 0.02 & 15 & 25 \\
0.2 & 0.1 & 0.3 & 0.05 & 29 & 104 \\
3.0 & 3.0 & 4.0 & 0.33 & 11 & 39 \\
0.6 & 0.5 & 0.8 & 0.08 & 12 & 27 \\
0.5 & 0.4 & 0.6 & 0.05 & 10 & 21 \\
1.0 & 0.1 & 1.9 & 0.48 & 47 & 55 \\
0.1 & 0.0 & 0.1 & 0.03 & 36 & 49 \\
2.2 & 1.8 & 2.6 & 0.18 & 8 & 21 \\
0.7 & 0.6 & 0.8 & 0.06 & 8 & 33 \\
30.0 & 27.0 & 32.0 & 1.94 & 7 & 15 \\
1.9 & 1.4 & 2.2 & 0.28 & 15 & 17 \\
1.3 & 1.0 & 1.4 & 0.13 & 10 & 11 \\
3.0 & 2.8 & 3.3 & 0.19 & 6 & 13 \\
1.5 & 1.3 & 1.6 & 0.12 & 8 & 10 \\
\hline & & & & &
\end{tabular}

under a stereo microscope (ZEISS Discovery V12) to the nearest $0.01 \mathrm{~mm}$. From the central part of a female spike of each specimen, 5 utricles and 5 glumes were isolated for measurements. Similarly, from the central part of the male spike of each specimen, 5 male glumes were isolated for measurements. For further analyses, mean values of the characters (utricles and glumes) were used. Utricles and glumes from the central part of the spike are regarded as the least variable ones, and are most often used in biometric studies (Blackstock \& Ashton 2010). The percentage ratio of beak length to utricle length $(\mathrm{B} / \mathrm{U})$ was calculated from the formula:

$$
\frac{\text { utricle beak length }(\mathrm{UBL})}{\text { total utricle length }(\mathrm{UL})} \times 100 \%
$$

Measurements under a stereo microscope were conducted at the Department of Invertebrate Zoology and Limnology, University of Szczecin.

\subsection{Estimation of fertility level}

During field research, some of the investigated populations were found to be mixed, composed of various taxa of the C. flava complex, including hybrids with lower fertility. Hence, fertility of live specimens was assessed on the basis of the percentage contribution of utricles with well-developed fruits. For this purpose, Hedrén's (2002) fertility scale was simplified as follows: $1-0 \%$ of well-developed fruits; $2-10 \%$ or less, but more than $0 \% ; 3-50 \%$ or less, but more than $10 \%$; 4 - less than $100 \%$, but more than $50 \% ; 5-100 \%$ of well-developed fruits. Sterile or less fertile specimens (scores 1-3) usually were morphologically intermediate between completely fertile specimens (score 5).

\subsection{Analysis of soil samples}

Soil samples were collected at each site from the depth of $0-15 \mathrm{~cm}$, then dried at room temperature, and next sieved to remove the fraction $>2 \mathrm{~mm}$. In the material prepared in this way, the following soil parameters were evaluated: organic matter content (loss on ignition), $\mathrm{pH}$ (in $1 \mathrm{M} \mathrm{KCl}$ ), assimilable nutrients $(\mathrm{P}, \mathrm{K}$, $\mathrm{Mg}$, and $\mathrm{Ca}$ - using the American Society of Agronomy method), carbonates (using Scheibler's method), and total $\mathrm{C}$ and $\mathrm{N}$ content (using CHNS chemical analyser, Costech Analytical Technologies Inc.).

All the soil analyses were performed at the Department of Environmental Reclamation and Chemistry, West Pomeranian Technological University, Szczecin.

\subsection{Statistical analysis}

OTUs were classified using Ward's minimum variance method, based on Euclidean distances. The distinguished OTUs were assigned a taxonomic status. First, welldefined taxa were distinguished, according to the taxonomic concept presented by Pykäla \& Toivonen (1994) and Hedrén (2003). Next, taxonomic status was given to completely sterile or partly fertile hybrids. For delimitation of the hybrids, field data were also used, i.e. coexistence (on the same site) of hybrids and putative parental species.

The hypothesis about morphological separation of the investigated sedge specimens was tested with the use of discriminant function analysis (DFA). The analysis required a priori assignment of each OTU to a selected taxon. The grouping of OTUs was possible thanks to the preceding classification procedure. DFA enabled comparison of percentage similarity of observed classifications (i.e. a priori defined) with classifications resulting from DFA, in the form of a classification matrix. In DFA, well-defined taxa should be assigned to distinct groups, whereas hybrids should be located in the DFA space defined by putative parents. DFA was performed in 3 steps. In the first step, the complete database was used. In the second step, C. flava s.s. and its hybrids were excluded from analyses. In the third step, C. flava, 
C. lepidocarpa, and their hybrids were excluded. In the successive steps of DFA, the excluded species (with hybrids) was the one that was best distinguished by discriminant functions of other members of the C. flava group. As a result, the most similar species remained in the last step: C. demissa and C. viridula. This procedure allowed a relatively precise determination of morphological characters that distinguished between the analysed taxa.

To estimate the total morphological variation of sedge specimens and to determine relations between them, principal component analysis (PCA) was performed on the basis of a correlation matrix. Hybrids, also in this analysis, should fill the phenetic space between putative parental taxa. PCA was performed in 3 steps, using the same procedure as in DFA. Additionally, PCA was performed separately for C. lepidocarpa and C. demissa, since these taxa were poorly separated by PCA.

In statistical analyses, all living specimens collected during field research were used except $C$. $\times$ subviridula (18 specimens) and C. viridula var. pulchella ( 9 specimens), which were found only in herbaria. Because of the large database (1852 living specimens), the scatterplots of DFA and PCA results, as well as the phenogram (phenetic tree) present data from a smaller data set, reduced to 561 specimens, including 409 specimens of well-defined taxa: 100 of C. flava s.s., 100 of C. lepidocarpa, 100 of $C$. demissa, 100 of $C$. viridula var. viridula, 9 of C. viridula var. pulchella, and 152 of hybrids.

Relationships between occurrence of taxa and soil parameters were tested using redundancy analysis (RDA, on the basis of the whole data set collected during field research), and presented as a scatterplot. Statistical significance of soil parameters and canonical axes was assessed by Monte Carlo permutation test (ter Braak \& Šmilauer 2002).

For each morphological character, basic statistics were calculated, i.e. arithmetic mean, range (minimum and maximum values), standard deviation, and coefficient of variation. Relations between morphological characters were assessed on the basis of Spearman's correlation coefficient. For soil parameters, arithmetic mean and minimum and maximum values were calculated. Significance of differences in mean values of morphological characters of the analysed taxa of sedges (A)

Table 3. Matrix of significance of Spearman's rank correlation coefficients for taxa of the Carex flava group: (A) C. flava s.s.; (B) C. lepidocarpa; (C) C. demissa; (D) C. viridula var. viridula

Explanations: $1,4,8 \ldots$ - character numbers as in Table 2 . Absolute values $\geq 0.80$ are marked in bold. Coefficients of correlation were not calculated for $C$. viridula var. pulchella because of the small number of specimens

\begin{tabular}{|c|c|c|c|c|c|c|c|c|c|c|c|c|c|c|c|c|c|c|}
\hline Character & 1 & 3 & 4 & 8 & 10 & 11 & 12 & 13 & 14 & 15 & 16 & 17 & 18 & 19 & 20 & 21 & 22 & 23 \\
\hline 42 & 0.11 & 0.05 & 0.02 & -0.10 & 0.25 & 0.25 & -0.16 & 0.07 & 0.11 & 0.22 & -0.03 & 0.12 & -0.16 & 0.39 & 0.24 & -0.01 & 0.31 & -0.34 \\
\hline 41 & -0.12 & 0.30 & 0.12 & 0.09 & -0.01 & 0.09 & 0.32 & -0.41 & 0.17 & -0.37 & 0.22 & 0.34 & 0.44 & -0.09 & 0.07 & 0.30 & 0.01 & 0.13 \\
\hline 38 & 0.11 & 0.48 & 0.02 & -0.14 & 0.40 & 0.35 & 0.22 & -0.17 & 0.31 & -0.14 & 0.36 & 0.40 & 0.32 & 0.09 & 0.29 & 0.42 & 0.27 & -0.03 \\
\hline 37 & -0.24 & 0.47 & 0.13 & 0.09 & 0.12 & 0.14 & 0.40 & -0.25 & 0.22 & -0.42 & 0.33 & 0.35 & 0.56 & -0.19 & 0.13 & 0.40 & 0.09 & 0.08 \\
\hline 34 & 0.25 & -0.29 & 0.08 & -0.16 & 0.06 & 0.10 & -0.21 & 0.22 & -0.10 & 0.28 & 0.00 & 0.08 & 0.03 & 0.11 & 0.03 & -0.20 & 0.01 & 0.08 \\
\hline 32 & -0.03 & 0.10 & 0.13 & 0.27 & -0.15 & -0.03 & 0.27 & -0.24 & 0.00 & -0.30 & 0.08 & 0.21 & 0.58 & -0.28 & -0.10 & 0.14 & -0.21 & 0.21 \\
\hline 29 & -0.16 & 0.23 & 0.10 & 0.34 & -0.19 & -0.06 & 0.39 & -0.36 & 0.00 & -0.40 & 0.05 & 0.19 & 0.62 & -0.32 & -0.12 & 0.23 & -0.22 & 0.17 \\
\hline 27 & -0.09 & 0.17 & -0.02 & -0.08 & 0.37 & 0.27 & 0.11 & -0.07 & 0.17 & -0.03 & 0.21 & 0.10 & 0.01 & 0.19 & 0.26 & 0.32 & 0.29 & -0.05 \\
\hline 26 & 0.37 & -0.01 & 0.26 & -0.34 & 0.35 & 0.36 & -0.13 & 0.09 & 0.14 & 0.25 & 0.07 & 0.23 & -0.07 & 0.26 & 0.50 & 0.05 & 0.35 & -0.04 \\
\hline 25 & -0.06 & 0.16 & 0.10 & 0.21 & -0.17 & 0.06 & 0.28 & -0.10 & -0.19 & -0.25 & -0.10 & 0.26 & 0.63 & -0.24 & -0.08 & 0.12 & -0.18 & 0.17 \\
\hline 24 & 0.19 & 0.13 & 0.14 & 0.03 & 0.25 & 0.46 & 0.21 & 0.24 & -0.12 & 0.12 & -0.10 & 0.37 & 0.29 & 0.11 & 0.24 & 0.25 & 0.10 & -0.01 \\
\hline 23 & -0.15 & -0.20 & -0.09 & 0.09 & -0.36 & -0.24 & 0.06 & -0.09 & -0.25 & -0.19 & -0.13 & -0.19 & 0.16 & -0.35 & -0.23 & -0.13 & -0.31 & \\
\hline 22 & 0.04 & 0.37 & 0.11 & -0.38 & 0.80 & 0.36 & 0.09 & 0.01 & 0.55 & 0.11 & 0.58 & 0.31 & -0.12 & 0.64 & 0.59 & 0.45 & & \\
\hline 21 & -0.01 & 0.67 & 0.23 & -0.07 & 0.55 & 0.44 & 0.47 & -0.17 & 0.53 & -0.28 & 0.54 & 0.51 & 0.28 & 0.27 & 0.47 & & & \\
\hline 20 & 0.25 & 0.46 & 0.59 & -0.29 & 0.72 & 0.52 & 0.23 & 0.02 & 0.58 & 0.00 & 0.52 & 0.45 & 0.07 & 0.54 & & & & \\
\hline 19 & 0.11 & 0.15 & 0.00 & -0.33 & 0.70 & 0.37 & 0.00 & 0.10 & 0.40 & 0.26 & 0.35 & 0.28 & -0.15 & & & & & \\
\hline 18 & -0.01 & 0.31 & 0.23 & 0.10 & -0.03 & 0.17 & 0.27 & -0.22 & 0.02 & -0.30 & 0.05 & 0.39 & & & & & & \\
\hline 17 & 0.28 & 0.53 & 0.44 & -0.10 & 0.48 & 0.65 & 0.41 & 0.00 & 0.36 & 0.04 & 0.29 & & & & & & & \\
\hline 16 & -0.04 & 0.49 & 0.25 & -0.26 & 0.62 & 0.14 & 0.19 & -0.38 & 0.87 & -0.50 & & & & & & & & \\
\hline 15 & 0.26 & -0.31 & -0.11 & -0.11 & 0.14 & 0.16 & -0.17 & 0.54 & -0.37 & & & & & & & & & \\
\hline 14 & 0.10 & 0.48 & 0.38 & -0.30 & 0.60 & 0.20 & 0.13 & -0.41 & & & & & & & & & & \\
\hline 13 & 0.16 & -0.13 & -0.10 & -0.05 & 0.09 & 0.24 & -0.06 & & & & & & & & & & & \\
\hline 12 & -0.19 & 0.37 & 0.31 & 0.22 & 0.14 & 0.20 & & & & & & & & & & & & \\
\hline 11 & 0.35 & 0.49 & 0.33 & -0.12 & 0.60 & & & & & & & & & & & & & \\
\hline 10 & 0.22 & 0.46 & 0.23 & -0.31 & & & & & & & & & & & & & & \\
\hline 8 & -0.44 & -0.12 & 0.02 & & & & & & & & & & & & & & & \\
\hline 4 & 0.34 & 0.38 & & & & & & & & & & & & & & & & \\
\hline 3 & 0.06 & & & & & & & & & & & & & & & & & \\
\hline
\end{tabular}


and in mean values of soil parameters at their sites was estimated by one-way analysis of variance (ANOVA). To determine more precisely the character of differences detected by ANOVA, the post hoc Tukey HSD test for unequal $N$ was used (Spjotvoll/Stoline test).

All the data used in multivariate statistical analyses were standardized, so that for each variable the arithmetic mean was 0 and standard deviation was 1 . Calculations were made with the use of statistical software: Statistica 8.0 (StatSoft, 2007) and Canoco 4.5 (ter Braak \& Šmilauer 2002).

\section{Results}

\subsection{Variation in morphological characters; pair-wise correlations}

Biometric analyses indicate that the $C$. flava group is characterized by exceptional morphological variation (Table 2). For the whole analysed dataset (excluding hybrids), high coefficients of variation $\left(V_{0} \geq 50 \%\right)$ were recorded for inflorescence length (IL), male spike peduncle length (MPL), distance between 2 uppermost

\begin{tabular}{cccccccccc}
\hline 24 & 25 & 26 & 27 & 29 & 32 & 34 & 37 & 38 & 41 \\
\hline 0.18 & -0.16 & 0.24 & 0.10 & -0.33 & -0.41 & -0.05 & -0.21 & 0.16 & -0.16 \\
0.04 & 0.35 & -0.09 & 0.08 & 0.51 & 0.48 & -0.06 & 0.59 & 0.34 & \\
0.26 & 0.21 & 0.07 & 0.21 & 0.28 & 0.23 & -0.04 & 0.54 & & \\
0.22 & 0.49 & -0.09 & 0.21 & 0.63 & 0.55 & -0.14 & & & \\
0.04 & -0.04 & 0.21 & -0.05 & -0.21 & 0.20 & & & & \\
0.25 & 0.64 & -0.10 & 0.12 & $\mathbf{0 . 8 8}$ & & & & & \\
0.22 & 0.67 & -0.19 & 0.15 & & & & & & \\
0.32 & 0.06 & 0.55 & & & & & & & \\
0.31 & -0.09 & & & & & & & & \\
0.40 & & & & & & & & &
\end{tabular}

female spikes (DUFS), distance between 2 lowest female spikes (DLFS), lowest female spike peduncle length (LPL), lowest female spike bract sheath length (LBSL), second female spike bract length (SBL), and culm height $(\mathrm{CH})$. The least variable characters $\left(V_{0} \leq 25 \%\right)$ include utricle length (UL), ratio of beak length to utricle length $(\mathrm{B} / \mathrm{U})$, dimensions of female and male glumes (FGL, FGW, MGL, and MGW), dimensions of female spikes (LFSL, LFSW, UFSW), male spike width (MSW), lowest female spike bract width (LBW), and uppermost cauline leaf width (CLW) (Table 2). Variability of individual characters was similar in all groups of analysed taxa (Table 2). For 2 characters only - uppermost female spike length (UFSL) and utricle beak length (UBL) - disparity was observed between $V$ calculated for the whole dataset $(27 \%$ and $33 \%$, respectively) and for individual taxa (12-20\% and $8-15 \%$, respectively).

The less variable characters $\left(V_{0} \leq 25 \%\right)$ seem to be most suitable for distinguishing between taxa of the $C$. flava complex. Most useful for delimitation are characters of utricles (UL, UBL, B/U), female spikes (LFSL, LFSW, UFSL, and UFSW), and bracts (LBW). Characters concerning dimensions of glumes (FGL, FGW, MGL, and MGW), male spike width (MSW), and uppermost cauline leaf width (CLW) are not highly variable but have similar ranges of values in all the compared taxa, so they are not useful for identification of species within C. flava agg. (Table 2).

Spearman's correlation coefficients (Tables 3A-D) show relatively high $(\geq 0.80)$ positive correlations $(i)$ between inflorescence length (IL) and distance between 2 lowest female spikes (DLFS) (Table 3C-D), lowest female spike peduncle length (LBL) (Table 3B), and lowest female spike bract sheath length (LBSL) (Table 3A); (ii) between number of female spikes (NFS) and distance between 2 lowest female spikes (DLFS) (Table 3A); (iii) between second female spike bract length (SBL) and width (SBW) (Table 3B and D); (iv) between cauline leaf length (CLL) and lowest female spike bract length (LBL) (Table 3C); ( $v$ ) between uppermost female spike length (UFSL) and width (UFSW) (Table 3B); and (vi) between utricle length (UL) and beak length (UBL) (Table 3A, C-D). High negative correlations were recorded between number of female spikes (NFS) and distance between 2 uppermost female spikes (DUFS) (Table 3D) and ratio of lowest female spike bract length to inflorescence length (B/I) (Table 3C).

\subsection{Morphological distinctness of taxa of Carex flava agg.}

Results of Ward's hierarchical clustering show division of specimens of C. flava agg. into clusters A, $\mathrm{B}, \mathrm{C}$, and $\mathrm{D}$, corresponding to well-defined species: 
(B)

\begin{tabular}{|c|c|c|c|c|c|c|c|c|c|c|c|c|c|c|c|c|c|c|}
\hline Character & 1 & 3 & 4 & 8 & 10 & 11 & 12 & 13 & 14 & 15 & 16 & 17 & 18 & 19 & 20 & 21 & 22 & 23 \\
\hline 42 & -0.20 & 0.48 & 0.16 & -0.10 & 0.38 & 0.21 & 0.32 & 0.02 & 0.32 & 0.32 & 0.23 & 0.43 & 0.29 & 0.45 & 0.41 & 0.42 & 0.38 & 0.16 \\
\hline 41 & -0.18 & 0.29 & 0.00 & -0.07 & 0.34 & 0.28 & 0.38 & 0.07 & 0.20 & 0.13 & 0.21 & 0.40 & 0.31 & 0.41 & 0.38 & 0.36 & 0.34 & 0.17 \\
\hline 38 & -0.01 & 0.22 & -0.01 & 0.01 & 0.09 & 0.11 & 0.18 & 0.12 & -0.02 & 0.04 & -0.02 & 0.23 & 0.21 & 0.11 & 0.06 & 0.08 & 0.02 & -0.05 \\
\hline 37 & 0.10 & -0.06 & -0.05 & 0.05 & 0.11 & 0.19 & 0.21 & 0.17 & -0.08 & 0.01 & -0.08 & 0.25 & 0.04 & 0.05 & 0.06 & 0.00 & 0.09 & -0.08 \\
\hline 34 & 0.06 & 0.02 & -0.12 & 0.11 & -0.09 & 0.03 & 0.00 & 0.02 & -0.01 & -0.04 & -0.01 & 0.11 & 0.00 & 0.11 & -0.06 & -0.02 & -0.06 & 0.03 \\
\hline 32 & 0.24 & 0.15 & 0.13 & 0.17 & 0.13 & 0.24 & 0.21 & 0.23 & -0.07 & 0.02 & -0.05 & 0.42 & 0.49 & 0.15 & 0.12 & 0.02 & 0.00 & 0.03 \\
\hline 29 & 0.24 & 0.19 & 0.28 & 0.16 & 0.26 & 0.28 & 0.28 & 0.29 & -0.08 & 0.08 & -0.04 & 0.48 & 0.68 & 0.13 & 0.22 & 0.07 & 0.10 & 0.02 \\
\hline 27 & -0.13 & 0.34 & 0.13 & -0.20 & 0.50 & 0.03 & 0.18 & -0.16 & 0.60 & 0.45 & 0.43 & 0.06 & -0.11 & 0.49 & 0.65 & 0.67 & 0.53 & 0.43 \\
\hline 26 & -0.19 & 0.41 & 0.15 & -0.19 & 0.55 & 0.08 & 0.22 & -0.11 & 0.62 & 0.47 & 0.46 & 0.14 & -0.03 & 0.55 & 0.70 & 0.72 & 0.54 & 0.46 \\
\hline 25 & -0.01 & 0.51 & 0.33 & -0.03 & 0.42 & 0.27 & 0.26 & -0.11 & 0.59 & 0.62 & 0.18 & 0.42 & 0.44 & 0.44 & 0.59 & 0.49 & 0.40 & 0.37 \\
\hline 24 & 0.02 & 0.45 & 0.28 & -0.09 & 0.44 & 0.39 & 0.33 & 0.07 & 0.47 & 0.70 & -0.02 & 0.47 & 0.26 & 0.48 & 0.58 & 0.45 & 0.40 & 0.34 \\
\hline 23 & -0.15 & 0.28 & 0.29 & -0.08 & 0.07 & -0.04 & -0.02 & -0.15 & 0.34 & 0.21 & 0.19 & 0.08 & 0.16 & 0.24 & 0.52 & 0.48 & 0.25 & \\
\hline 22 & -0.18 & 0.35 & 0.01 & -0.11 & 0.66 & 0.10 & 0.26 & -0.03 & 0.50 & 0.55 & 0.32 & 0.21 & -0.01 & 0.63 & 0.68 & 0.68 & & \\
\hline 21 & -0.30 & 0.52 & 0.08 & -0.17 & 0.58 & 0.07 & 0.18 & -0.14 & 0.63 & 0.48 & 0.47 & 0.22 & 0.05 & 0.65 & 0.75 & & & \\
\hline 20 & -0.02 & 0.54 & 0.46 & -0.15 & 0.82 & 0.32 & 0.31 & 0.12 & 0.56 & 0.63 & 0.38 & 0.43 & 0.27 & 0.70 & & & & \\
\hline 19 & -0.17 & 0.59 & 0.11 & -0.14 & 0.69 & 0.27 & 0.33 & 0.08 & 0.47 & 0.53 & 0.34 & 0.47 & 0.16 & & & & & \\
\hline 18 & 0.25 & 0.40 & 0.44 & 0.08 & 0.25 & 0.43 & 0.37 & 0.31 & -0.10 & 0.08 & -0.05 & 0.62 & & & & & & \\
\hline 17 & 0.19 & 0.58 & 0.39 & 0.00 & 0.50 & 0.76 & 0.63 & 0.44 & 0.04 & 0.24 & 0.00 & & & & & & & \\
\hline 16 & -0.16 & 0.17 & 0.05 & 0.05 & 0.37 & -0.13 & -0.01 & -0.48 & 0.74 & -0.10 & & & & & & & & \\
\hline 15 & 0.03 & 0.41 & 0.29 & -0.12 & 0.57 & 0.23 & 0.26 & 0.03 & 0.43 & & & & & & & & & \\
\hline 14 & -0.15 & 0.32 & 0.14 & -0.05 & 0.43 & -0.07 & 0.04 & -0.60 & & & & & & & & & & \\
\hline 13 & 0.23 & 0.16 & 0.21 & -0.05 & 0.30 & 0.55 & 0.30 & & & & & & & & & & & \\
\hline 12 & 0.06 & 0.45 & 0.20 & -0.01 & 0.43 & 0.61 & & & & & & & & & & & & \\
\hline 11 & 0.24 & 0.47 & 0.33 & -0.03 & 0.49 & & & & & & & & & & & & & \\
\hline 10 & 0.10 & 0.52 & 0.37 & -0.09 & & & & & & & & & & & & & & \\
\hline 8 & 0.11 & -0.11 & 0.07 & & & & & & & & & & & & & & & \\
\hline 4 & 0.48 & 0.35 & & & & & & & & & & & & & & & & \\
\hline 3 & 0.04 & & & & & & & & & & & & & & & & & \\
\hline
\end{tabular}

(C)

\begin{tabular}{|c|c|c|c|c|c|c|c|c|c|c|c|c|c|c|c|c|c|c|}
\hline Character & 1 & 3 & 4 & 8 & 10 & 11 & 12 & 13 & 14 & 15 & 16 & 17 & 18 & 19 & 20 & 21 & 22 & 23 \\
\hline 42 & 0.27 & 0.21 & 0.10 & -0.30 & 0.08 & 0.07 & 0.08 & 0.04 & 0.02 & 0.04 & 0.07 & 0.11 & 0.21 & 0.04 & 0.10 & 0.24 & 0.09 & -0.05 \\
\hline 41 & 0.30 & 0.20 & 0.32 & -0.06 & 0.00 & 0.17 & 0.26 & 0.00 & 0.14 & 0.04 & -0.02 & 0.30 & 0.49 & 0.28 & 0.22 & 0.28 & -0.07 & 0.13 \\
\hline 38 & 0.29 & 0.21 & 0.29 & -0.13 & 0.16 & 0.25 & 0.27 & 0.17 & 0.03 & 0.16 & 0.14 & 0.24 & 0.20 & 0.03 & 0.27 & 0.27 & 0.15 & -0.02 \\
\hline 37 & 0.42 & 0.24 & 0.41 & -0.14 & 0.08 & 0.38 & 0.28 & 0.12 & 0.10 & 0.15 & 0.01 & 0.44 & 0.63 & 0.17 & 0.27 & 0.33 & 0.05 & 0.06 \\
\hline 34 & 0.20 & 0.16 & -0.07 & -0.34 & -0.06 & -0.06 & -0.10 & -0.09 & 0.00 & -0.05 & -0.02 & 0.05 & 0.05 & -0.18 & -0.07 & 0.13 & -0.01 & 0.03 \\
\hline 32 & 0.49 & 0.23 & 0.30 & -0.32 & 0.12 & 0.30 & 0.12 & 0.09 & 0.14 & 0.15 & 0.08 & 0.39 & 0.59 & 0.11 & 0.22 & 0.34 & 0.11 & -0.02 \\
\hline 29 & 0.47 & 0.20 & 0.40 & -0.17 & 0.17 & 0.39 & 0.21 & 0.16 & 0.18 & 0.21 & 0.09 & 0.46 & 0.69 & 0.26 & 0.31 & 0.34 & 0.15 & -0.02 \\
\hline 27 & 0.26 & 0.26 & 0.21 & -0.12 & 0.32 & 0.22 & 0.18 & 0.43 & -0.16 & 0.13 & 0.34 & 0.21 & 0.15 & 0.14 & 0.29 & 0.36 & 0.23 & -0.18 \\
\hline 26 & 0.40 & 0.24 & 0.49 & 0.08 & 0.36 & 0.28 & 0.23 & 0.42 & -0.10 & 0.23 & 0.36 & 0.26 & 0.25 & 0.08 & 0.62 & 0.34 & 0.28 & -0.09 \\
\hline 25 & 0.36 & 0.22 & 0.36 & -0.07 & 0.22 & 0.46 & 0.28 & 0.28 & 0.05 & 0.31 & 0.11 & 0.45 & 0.63 & 0.22 & 0.31 & 0.35 & 0.15 & -0.07 \\
\hline 24 & 0.37 & 0.21 & 0.36 & -0.06 & 0.29 & 0.55 & 0.25 & 0.57 & -0.16 & 0.43 & 0.16 & 0.56 & 0.44 & 0.24 & 0.35 & 0.29 & 0.19 & -0.11 \\
\hline 23 & -0.02 & 0.01 & 0.23 & 0.23 & -0.81 & -0.24 & 0.02 & -0.26 & -0.20 & -0.15 & -0.76 & 0.06 & 0.06 & -0.38 & -0.06 & -0.15 & -0.54 & \\
\hline 22 & 0.30 & 0.14 & 0.16 & -0.13 & 0.70 & 0.28 & 0.04 & 0.19 & 0.30 & 0.19 & 0.67 & 0.14 & 0.18 & 0.28 & 0.44 & 0.24 & & \\
\hline 21 & 0.42 & 0.62 & 0.39 & -0.08 & 0.40 & 0.37 & 0.16 & 0.02 & 0.41 & 0.09 & 0.37 & 0.36 & 0.30 & 0.22 & 0.49 & & & \\
\hline 20 & 0.67 & 0.33 & 0.84 & 0.12 & 0.52 & 0.41 & 0.30 & 0.13 & 0.44 & 0.30 & 0.50 & 0.47 & 0.42 & 0.30 & & & & \\
\hline 19 & 0.14 & 0.03 & 0.20 & 0.00 & 0.50 & 0.23 & 0.16 & 0.13 & 0.32 & 0.19 & 0.45 & 0.26 & 0.15 & & & & & \\
\hline 18 & 0.54 & 0.27 & 0.52 & -0.07 & 0.14 & 0.44 & 0.34 & 0.16 & 0.10 & 0.25 & 0.04 & 0.60 & & & & & & \\
\hline 17 & 0.62 & 0.39 & 0.57 & -0.08 & 0.16 & 0.61 & 0.25 & 0.26 & 0.14 & 0.36 & 0.04 & & & & & & & \\
\hline 16 & 0.30 & 0.16 & 0.15 & -0.15 & 0.93 & 0.22 & 0.08 & 0.12 & 0.52 & 0.11 & & & & & & & & \\
\hline 15 & 0.35 & 0.05 & 0.31 & 0.01 & 0.30 & 0.61 & 0.15 & 0.52 & -0.17 & & & & & & & & & \\
\hline 14 & 0.30 & 0.32 & 0.31 & 0.00 & 0.43 & 0.08 & 0.10 & -0.44 & & & & & & & & & & \\
\hline 13 & 0.11 & -0.07 & 0.11 & -0.05 & 0.29 & 0.53 & 0.21 & & & & & & & & & & & \\
\hline 12 & 0.28 & 0.04 & 0.39 & -0.06 & 0.17 & 0.26 & & & & & & & & & & & & \\
\hline 11 & 0.43 & 0.32 & 0.42 & -0.04 & 0.42 & & & & & & & & & & & & & \\
\hline 10 & 0.35 & 0.17 & 0.20 & -0.13 & & & & & & & & & & & & & & \\
\hline 8 & -0.32 & 0.00 & 0.17 & & & & & & & & & & & & & & & \\
\hline
\end{tabular}




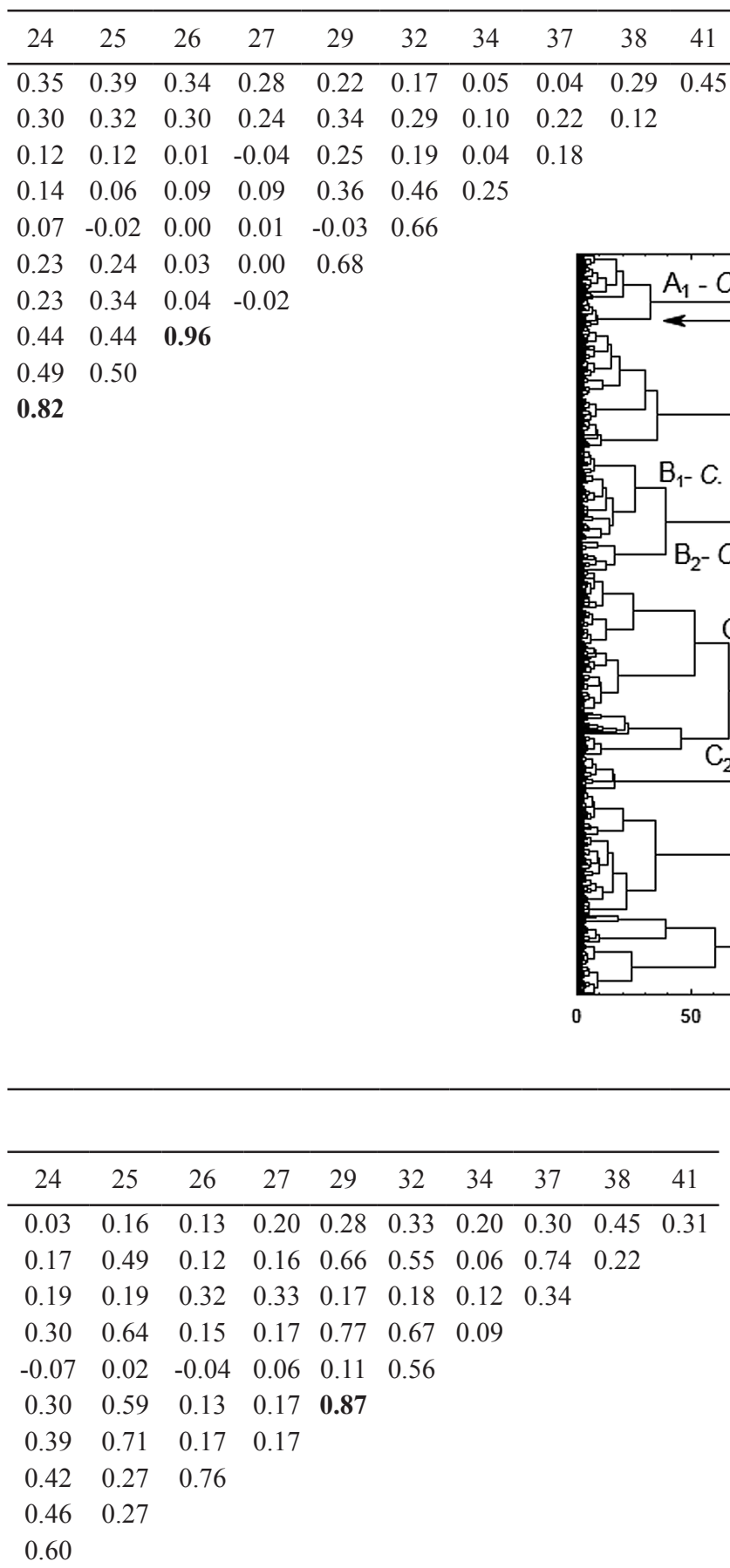

C. demissa, C. viridula, C. lepidocarpa, and C. flava s.s., respectively (Fig. 1). Cluster B (C. viridula) includes specimens representing both varieties: the typical var. viridula and the smaller-sized var. pulchella. Hybrid 
(D)

\begin{tabular}{|c|c|c|c|c|c|c|c|c|c|c|c|c|c|c|c|c|c|c|}
\hline Character & 1 & 3 & 4 & 8 & 10 & 11 & 12 & 13 & 14 & 15 & 16 & 17 & 18 & 19 & 20 & 21 & 22 & 23 \\
\hline 42 & 0.18 & 0.05 & 0.17 & -0.05 & 0.28 & 0.35 & 0.10 & 0.16 & -0.16 & 0.21 & 0.15 & 0.26 & 0.16 & 0.03 & 0.26 & 0.00 & 0.18 & -0.14 \\
\hline 41 & 0.18 & 0.19 & 0.09 & -0.08 & 0.41 & 0.46 & 0.13 & 0.29 & -0.14 & 0.28 & 0.23 & 0.36 & 0.31 & 0.07 & 0.32 & 0.24 & 0.25 & -0.18 \\
\hline 38 & 0.15 & 0.03 & 0.17 & -0.08 & 0.28 & 0.36 & -0.06 & 0.25 & -0.18 & 0.23 & 0.13 & 0.16 & 0.19 & 0.02 & 0.28 & 0.04 & 0.18 & 0.00 \\
\hline 37 & 0.26 & 0.22 & 0.21 & -0.08 & 0.31 & 0.42 & 0.10 & 0.39 & -0.29 & 0.38 & 0.13 & 0.34 & 0.49 & -0.02 & 0.29 & 0.21 & 0.28 & -0.12 \\
\hline 34 & 0.06 & -0.02 & 0.08 & 0.04 & 0.11 & 0.14 & 0.10 & 0.12 & 0.03 & 0.05 & 0.07 & 0.23 & 0.10 & 0.03 & 0.14 & 0.09 & 0.06 & 0.04 \\
\hline 32 & 0.30 & 0.20 & 0.23 & -0.12 & 0.25 & 0.34 & 0.10 & 0.28 & -0.13 & 0.27 & 0.09 & 0.42 & 0.57 & -0.02 & 0.27 & 0.29 & 0.19 & -0.09 \\
\hline 29 & 0.36 & 0.30 & 0.24 & -0.19 & 0.26 & 0.33 & 0.06 & 0.29 & -0.18 & 0.32 & 0.09 & 0.41 & 0.68 & -0.04 & 0.26 & 0.33 & 0.24 & -0.15 \\
\hline 27 & 0.17 & 0.00 & 0.08 & -0.08 & 0.37 & 0.38 & 0.15 & 0.09 & -0.07 & 0.22 & 0.35 & 0.20 & 0.11 & 0.14 & 0.39 & 0.17 & 0.31 & -0.01 \\
\hline 26 & 0.31 & 0.06 & 0.18 & -0.16 & 0.41 & 0.47 & 0.10 & 0.20 & -0.15 & 0.27 & 0.34 & 0.24 & 0.18 & 0.08 & 0.48 & 0.10 & 0.35 & 0.01 \\
\hline 25 & 0.33 & 0.41 & 0.25 & -0.12 & 0.25 & 0.49 & 0.13 & 0.46 & -0.38 & 0.52 & -0.01 & 0.52 & 0.74 & -0.08 & 0.25 & 0.36 & 0.20 & -0.09 \\
\hline 24 & 0.32 & 0.24 & 0.28 & -0.04 & 0.33 & 0.61 & 0.15 & 0.55 & -0.51 & 0.64 & 0.05 & 0.54 & 0.50 & -0.06 & 0.35 & 0.23 & 0.22 & -0.08 \\
\hline 23 & 0.24 & 0.00 & 0.41 & 0.00 & -0.28 & -0.12 & -0.13 & -0.11 & 0.18 & -0.23 & -0.14 & 0.06 & -0.01 & -0.05 & 0.27 & -0.08 & 0.03 & \\
\hline 22 & 0.18 & 0.11 & 0.16 & -0.14 & 0.39 & 0.18 & 0.11 & 0.12 & 0.07 & 0.10 & 0.39 & 0.22 & 0.13 & 0.27 & 0.50 & 0.31 & & \\
\hline 21 & 0.09 & 0.55 & 0.14 & 0.01 & 0.39 & 0.13 & 0.16 & 0.08 & 0.19 & 0.08 & 0.35 & 0.36 & 0.27 & 0.25 & 0.32 & & & \\
\hline 20 & 0.55 & 0.18 & 0.68 & -0.10 & 0.67 & 0.48 & 0.07 & 0.18 & 0.14 & 0.19 & 0.58 & 0.45 & 0.24 & 0.30 & & & & \\
\hline 19 & 0.07 & 0.13 & 0.08 & -0.05 & 0.34 & -0.02 & -0.03 & -0.13 & 0.25 & -0.06 & 0.39 & 0.07 & -0.13 & & & & & \\
\hline 18 & 0.45 & 0.33 & 0.37 & -0.16 & 0.14 & 0.43 & 0.11 & 0.32 & -0.24 & 0.35 & -0.08 & 0.57 & & & & & & \\
\hline 17 & 0.47 & 0.34 & 0.53 & -0.05 & 0.32 & 0.51 & 0.26 & 0.30 & -0.02 & 0.23 & 0.12 & & & & & & & \\
\hline 16 & 0.14 & 0.14 & 0.13 & -0.10 & 0.81 & 0.21 & 0.08 & -0.07 & 0.36 & 0.01 & & & & & & & & \\
\hline 15 & 0.20 & 0.09 & 0.09 & -0.06 & 0.34 & 0.62 & -0.03 & 0.61 & -0.80 & & & & & & & & & \\
\hline 14 & -0.04 & 0.07 & 0.09 & 0.05 & 0.07 & -0.45 & 0.17 & -0.56 & & & & & & & & & & \\
\hline 13 & 0.22 & 0.12 & 0.15 & -0.10 & 0.25 & 0.56 & -0.08 & & & & & & & & & & & \\
\hline 12 & -0.01 & 0.10 & -0.04 & 0.06 & 0.09 & 0.04 & & & & & & & & & & & & \\
\hline 11 & 0.45 & 0.11 & 0.34 & -0.15 & 0.54 & & & & & & & & & & & & & \\
\hline 10 & 0.27 & 0.20 & 0.24 & -0.09 & & & & & & & & & & & & & & \\
\hline 8 & -0.53 & 0.01 & -0.02 & & & & & & & & & & & & & & & \\
\hline 4 & 0.72 & 0.21 & & & & & & & & & & & & & & & & \\
\hline 3 & 0.14 & & & & & & & & & & & & & & & & & \\
\hline
\end{tabular}

clearly distinguishes $C$. flava, whose canonical means are positive, from the other taxa, whose canonical means are negative. The second function highlights the phenetic distinctness of $C$. lepidocarpa (Fig. 2A). Along the second axis, coordinates for $C$. lepidocarpa are positive,

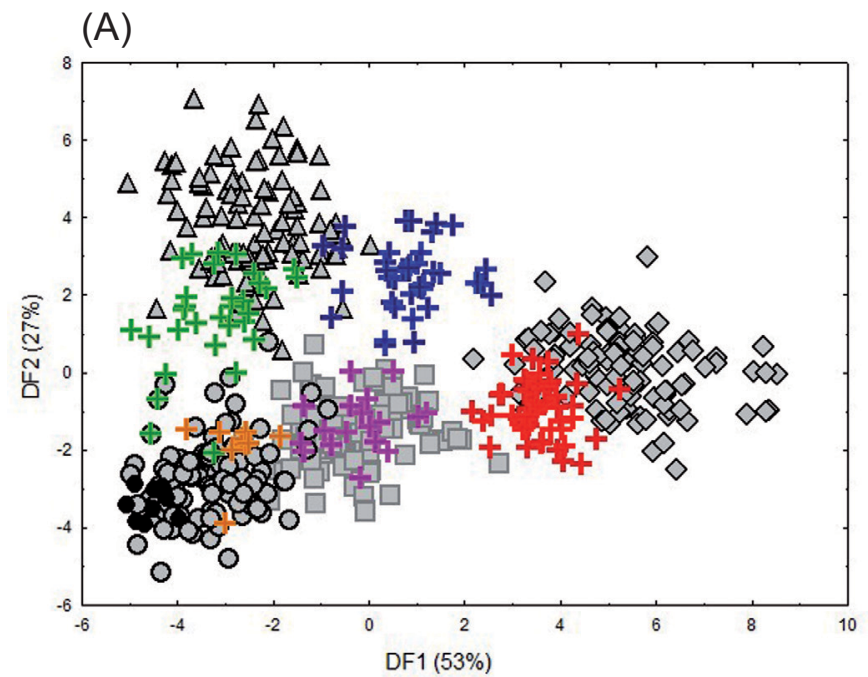

whereas for the other taxa they are negative. The third discriminant function separates $C$. demissa, but the third axis explains only $13 \%$ of the total variation (Fig. 2 B). DFA performed after exclusion of $C$. flava s.s., shows a clear morphological distinctness of the group of speci-

(B)

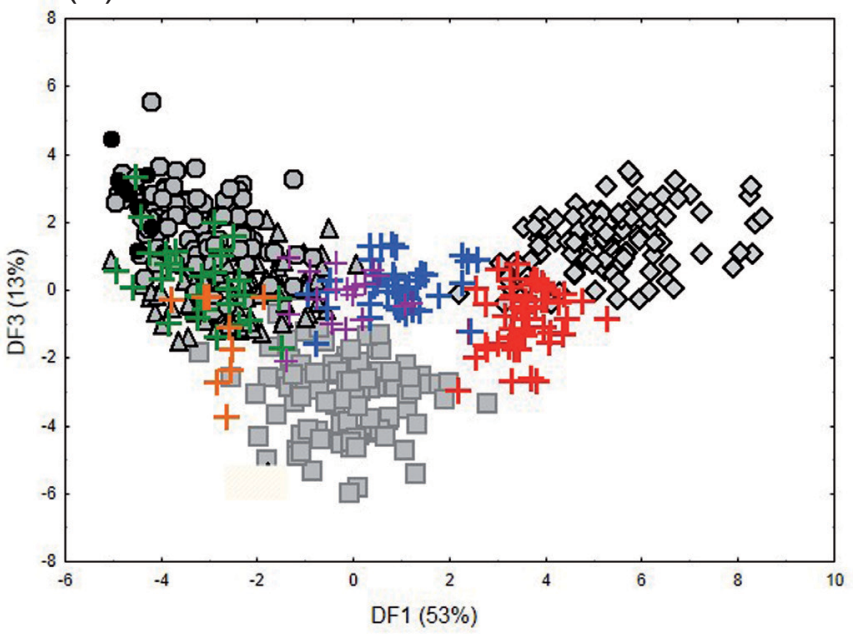

Fig. 2. Results of discriminant analysis (DFA) for the whole dataset of the Carex flava group: (A) along axes DF1 and DF2; (B) along axes DF1 and DF3

Explanations: $\diamond-$ C. flava, $\bigcirc-$ C. viridula var. viridula, - C. viridula var. pulchella, $\square-$ C. demissa, $\triangle-$ C. lepidocarpa $,+-C . \times a l s a t i c a,+-C$. $\times$ ruedtii, +- C. $\times$ schatzii, $+-C$. $\times$ subviridula,+- . demissa $\times$ C. viridula. Loadings for the first axis (only absolute values $>0.50$ are given, characters abbreviated as in Table 2): $\mathrm{UL}=0.68, \mathrm{UBL}=1.47$. Loadings for the second axis: $\mathrm{UBL}=-1.19, \mathrm{U} / \mathrm{B}=0.60, \mathrm{UL}=1.29$. Loadings for the third axis: $\mathrm{UBL}=$ 2.11, $\mathrm{MGL}=-0.66, \mathrm{~B} / \mathrm{U}=-1.46, \mathrm{UL}=-1.46$ 


\begin{tabular}{ccccccccccc}
\hline 24 & 25 & 26 & 27 & 29 & 32 & 34 & 37 & 38 & 41 \\
\hline 0.22 & 0.15 & 0.27 & 0.18 & 0.29 & 0.24 & 0.04 & 0.38 & 0.40 & 0.55 \\
0.41 & 0.41 & 0.38 & 0.28 & 0.45 & 0.42 & 0.15 & 0.55 & 0.39 & \\
0.29 & 0.28 & 0.21 & 0.15 & 0.30 & 0.21 & -0.05 & 0.55 & & \\
0.48 & 0.54 & 0.27 & 0.15 & 0.60 & 0.55 & 0.19 & & & \\
0.12 & 0.14 & 0.17 & 0.15 & 0.15 & 0.64 & & & & \\
0.43 & 0.61 & 0.25 & 0.18 & $\mathbf{0 . 8 3}$ & & & & & \\
0.47 & 0.70 & 0.19 & 0.12 & & & & & & \\
0.21 & 0.20 & $\mathbf{0 . 8 5}$ & & & & & & & \\
0.29 & 0.23 & & & & & & & & \\
0.72 & & & & & & & & &
\end{tabular}

mens of $C$. lepidocarpa, especially along the first axis, explaining $56 \%$ of the variation (Fig. 3). The first axis is most strongly affected by utricle characters (UL and UBL), culm height $(\mathrm{CH})$, and second female spike bract width (SBW). The second axis separates $C$. demissa

(A)

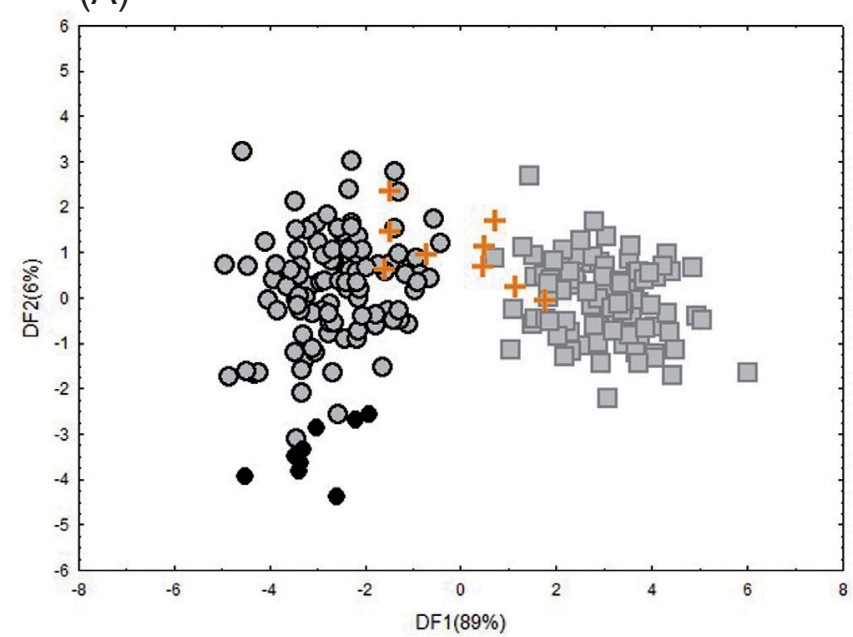

(A)

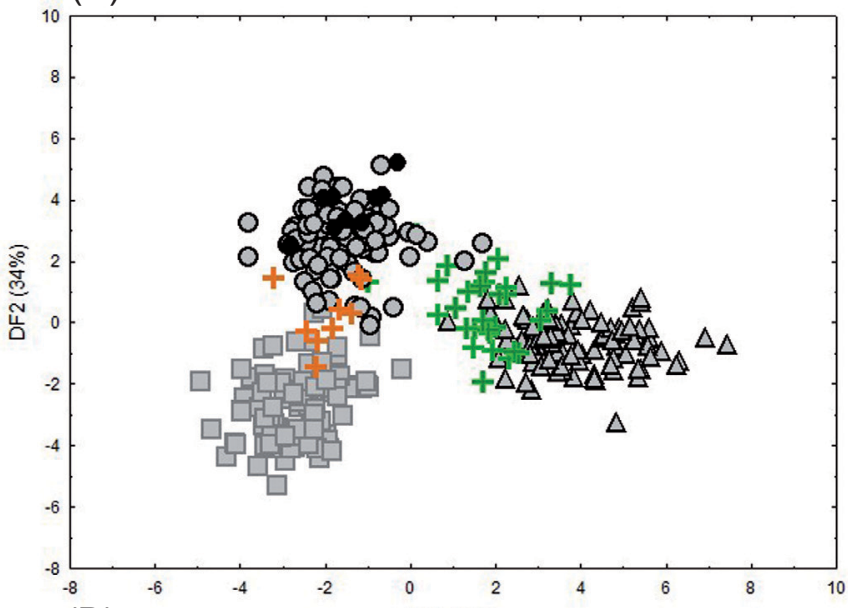

(B)

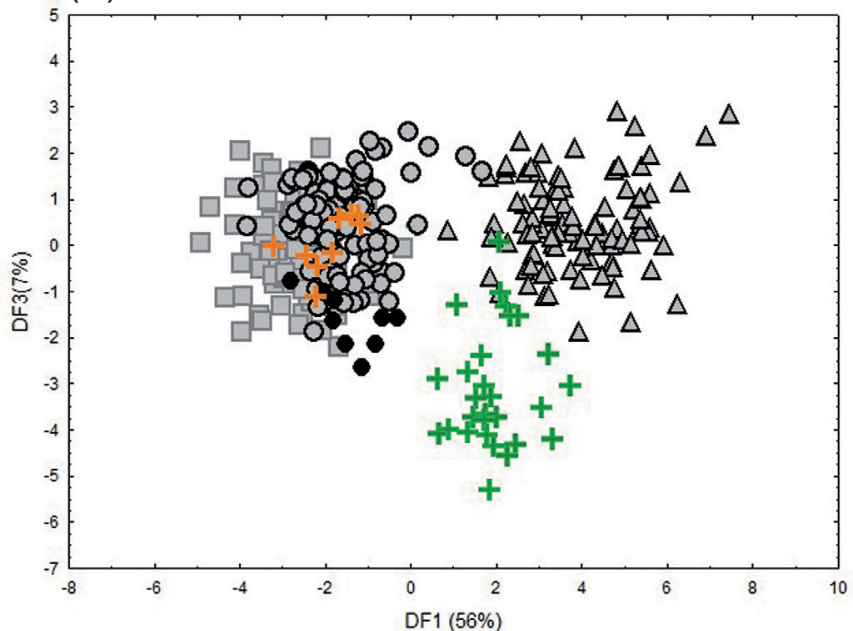

Fig. 3. Results of discriminant analysis (DFA) for a reduced dataset (after exclusion of Carex flava and its hybrids): (A) along axes DF1 and DF2; (B) along axes DF1 and DF3

Explanations: $\mathrm{O}-\mathrm{C}$. viridula var. viridula, - C. viridula var. pulchella, $\square-C$. demissa, $\triangle-$ C. lepidocarpa,$+-C$. $\times$ schatzii, +- C. demissa $\times C$. viridula. Loadings for the first axis (only absolute values $>0.50$ are given, characters abbreviated as in Table 2): $\mathrm{UL}=1.04, \mathrm{UBL}=-0.99, \mathrm{CH}$ $=0.74, \mathrm{SBW}=-0.65$. Loadings for the second axis: $\mathrm{B} / \mathrm{U}=-0.76$. Loadings for the third axis: $\mathrm{LBL}=-0.97, \mathrm{UL}=0.90, \mathrm{UBL}=-0.67, \mathrm{SBL}=0.58, \mathrm{LBW}$ $=0.57, \mathrm{NFS}=0.56, \mathrm{CH}=0.54$

(B)

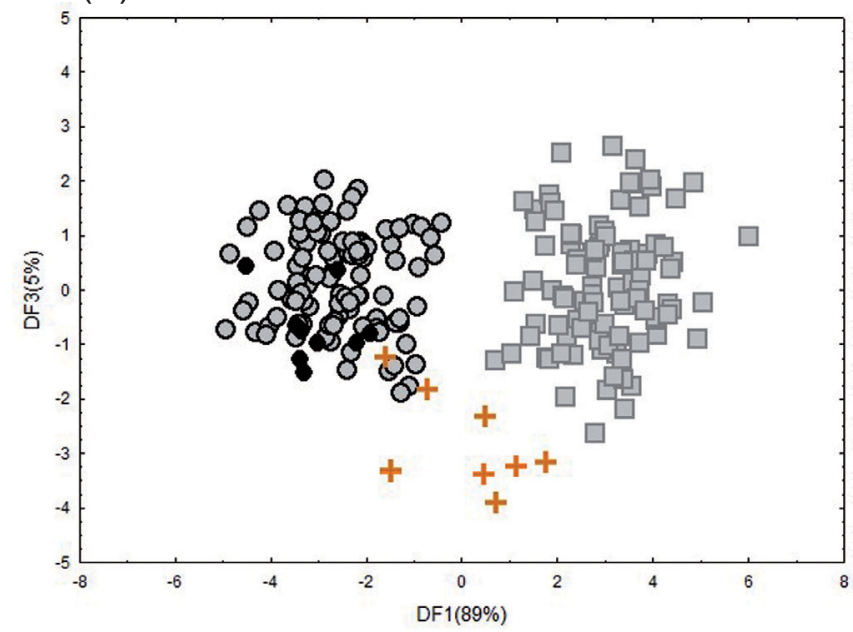

Fig. 4. Results of discriminant analysis (DFA) for a reduced dataset (after exclusion of Carex flava, C. lepidocarpa, and their hybrids): (A) along axes DF1 and DF2; (B) along axes DF1 and DF3

Explanations: $\mathrm{O}-$ C. viridula var. viridula, $\bullet-$ C. viridula var. pulchella, $\square-$ C. demissa, +- C. demissa $\times$ C. viridula . Loadings for the first axis (only absolute values $>0.50$ are given, characters abbreviated as in Table 2): $\mathrm{B} / \mathrm{I}=-0.60, \mathrm{UBL}=0.58$. Loadings for the second axis: $\mathrm{UBL}=-3.49, \mathrm{UL}=3.25, \mathrm{~B} / \mathrm{U}$ $=1.99, \mathrm{NFS}=0.76, \mathrm{SBL}=0.72$. Loadings for the third axis: $\mathrm{UL}=-0.97, \mathrm{UBL}=0.92, \mathrm{LFSW}=0.62, \mathrm{UFSW}=0.53$ 
(A)

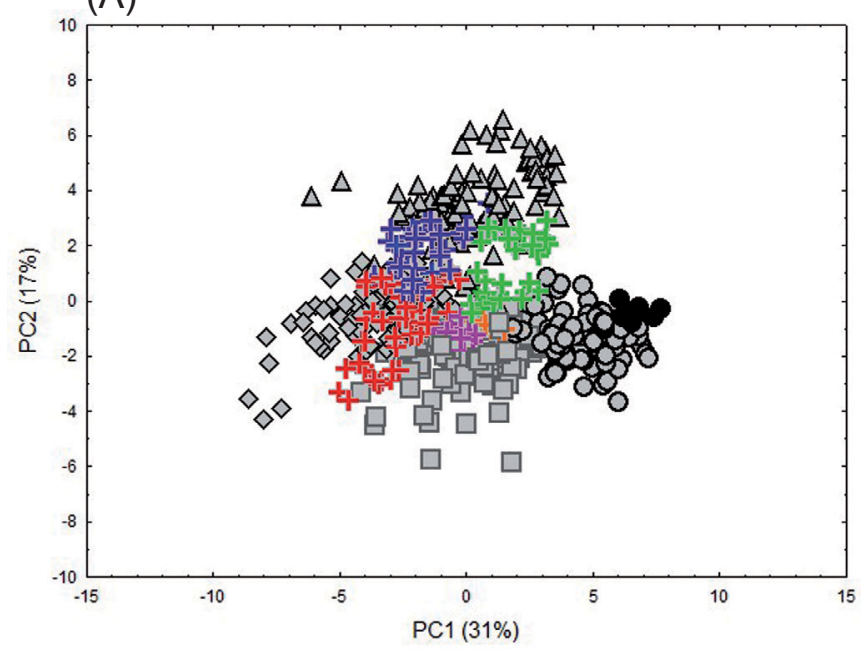

(B)

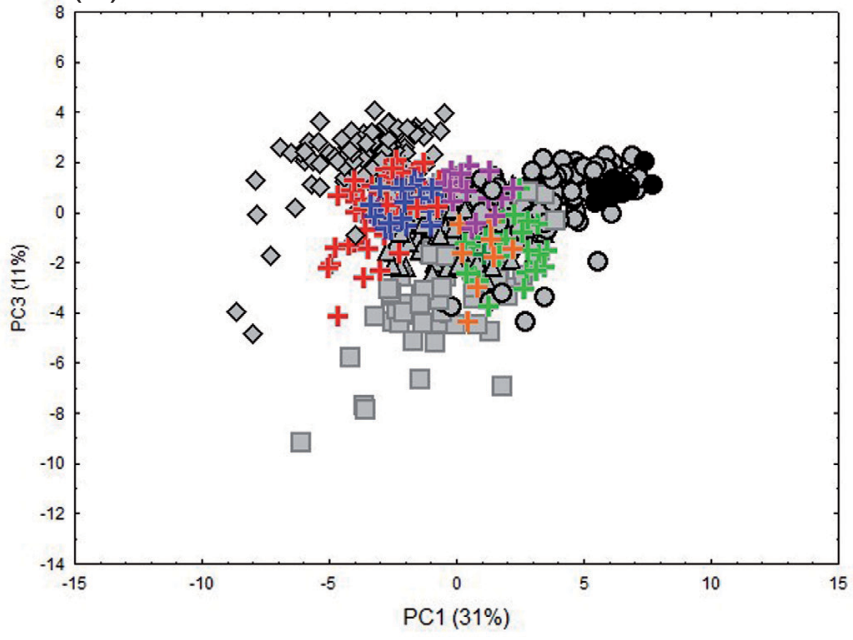

Fig. 5. Results of principal component analysis (PCA) for the whole dataset: (A) along axes PC1 and PC2; (B) along axes PC1 and PC3 Explanations: $\diamond-$ C. flava, $\bigcirc-C$. viridula var. viridula, - C. viridula var. pulchella, $\square-$ C. demissa, $\triangle-$ C. lepidocarpa $,+-C . \times a l s a t i c a,+-C . \times r u e d t i i$, +- C. $\times$ schatzii,$+-C$. $\times$ subviridula,$+-C$. demissa $\times$ C. viridula . Loadings for the first axis (only absolute values $>0.50$ are given, characters abbreviated as in Table 2): $\mathrm{CH}=-0.53, \mathrm{CLW}=-0.75, \mathrm{CLL}=-0.66, \mathrm{MSL}=-0.59, \mathrm{LFSL}=-0.80, \mathrm{LFSW}=-0.85, \mathrm{LBL}=-0.64, \mathrm{LBW}=-0.57, \mathrm{UFSL}=-0.70, \mathrm{UFSW}=-0.69$, $\mathrm{SBL}=-0.55, \mathrm{UL}=-0.87, \mathrm{UBL}=-0.87, \mathrm{~B} / \mathrm{U}=-0.74, \mathrm{FGL}=-0.82, \mathrm{FGW}=-0.56, \mathrm{MGL}=-0.56$ ). Loadings for the second axis: $\mathrm{CH}=0.56, \mathrm{MPL}=0.70, \mathrm{NFS}=$ $-0.82, \mathrm{DLFS}=-0.55, \mathrm{LBW}=-0.66, \mathrm{SBL}=-0.58, \mathrm{SBW}=-0.68)$. Loadings for the third axis: $\mathrm{C} / \mathrm{L}=0.50, \mathrm{IL}=-0.83, \mathrm{DLFS}=-0.64, \mathrm{LBSL}=-0.67, \mathrm{~B} / \mathrm{I}=0.79$

from $C$. viridula, mostly on the basis of the ratio of beak length to utricle length (B/U) (Fig. 3A). The next discriminant analysis, performed after exclusion of $C$. flava and C. lepidocarpa, confirms the morphological separateness of $C$. demissa (Fig. 4). The most significant first axis explains $89 \%$ of the variance. It is primarily associated with utricle beak length (UBL) and the ratio of lowest female spike bract length to inflorescence length (B/I). C. demissa has longer beaks than C. viridula, as their mean values are $1.3 \mathrm{~mm}$ and $0.9 \mathrm{~mm}$, respectively.
The lowest female spike bracts in specimens of C. demiss $a$ are usually as long as the inflorescence, whereas in specimens of $C$. viridula they are usually much longer; however, bract length in specimens of $C$. demissa is highly variable $\left(V_{3}=49 \%\right)$ (Table 2$)$.

The analysed taxa are poorly segregated by principal component analysis (PCA), with the first, second, and third component explaining $31 \%, 17 \%$, and $11 \%$ of the variance (Fig. 5). Along the first axis, specimens of $C$. flava s.s. and C. viridula form 2 clearly separate
(A)

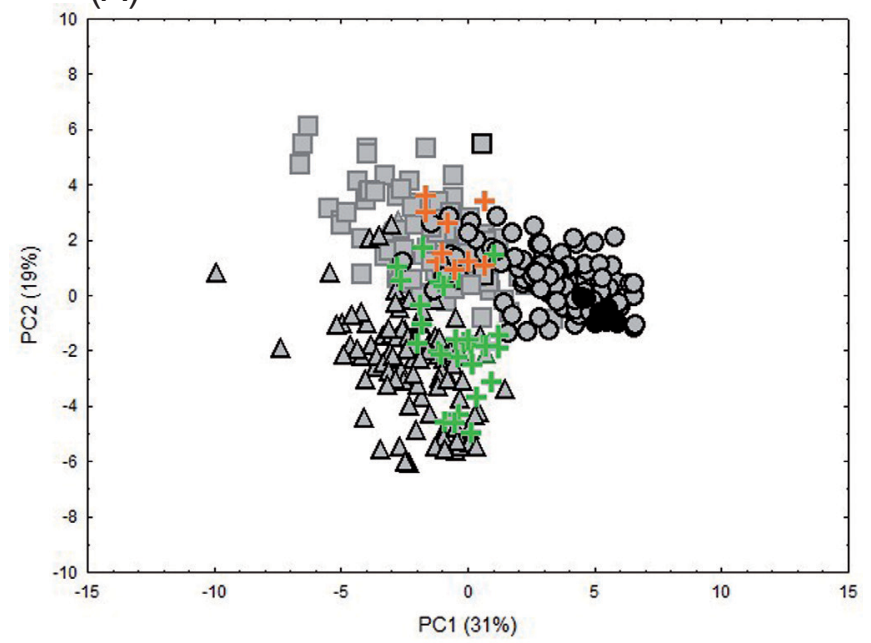

(B)

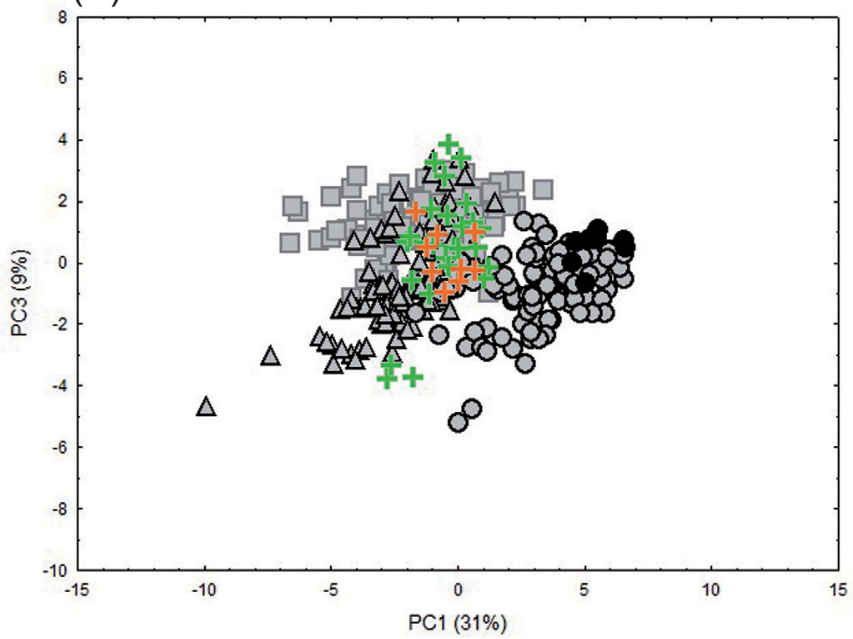

Fig. 6. Results of principal component analysis (PCA) for a reduced dataset (after exclusion of Carex flava and its hybrids): (A) along axes PC1 and PC2; (B) along axes PC1 and PC3

Explanations: $\bigcirc-$ C. viridula var. viridula, - C. viridula var. pulchella, $\square-$ C. demissa, $\triangle-$ C. lepidocarpa,+- C. $\times$ schatzii, +- C. demissa $\times$ C. viridula. Loadings for the first axis (only absolute values $>0.50$ are given, characters abbreviated as in Table 2): $\mathrm{CH}=-0.68, \mathrm{CLW}=-0.60, \mathrm{C} / \mathrm{L}=0.61, \mathrm{IL}=$ $-0.56, \mathrm{MSL}=-0.77, \mathrm{MPL}=-0.54, \mathrm{LFSL}=-0.79, \mathrm{LFSW}=-0.81, \mathrm{UL}=-0.86, \mathrm{UBL}=-0.85, \mathrm{~B} / \mathrm{U}=-0.56, \mathrm{FGL}=-0.78, \mathrm{FGW}=-0.62, \mathrm{MGL}=-0.63 . \mathrm{Loadings}$ for the second axis: $\mathrm{IL}=0.50, \mathrm{MPL}=-0.55, \mathrm{NFS}=0.78, \mathrm{DLFS}=0.67, \mathrm{LBL}=0.62, \mathrm{LBW}=0.86, \mathrm{LBSL}=0.51, \mathrm{SBL}=0.78, \mathrm{SBW}=0.82 . \mathrm{Loadings}$ for the third axis: $\mathrm{CLL}=-0.73, \mathrm{~B} / \mathrm{U}=0.56$ 
(A)

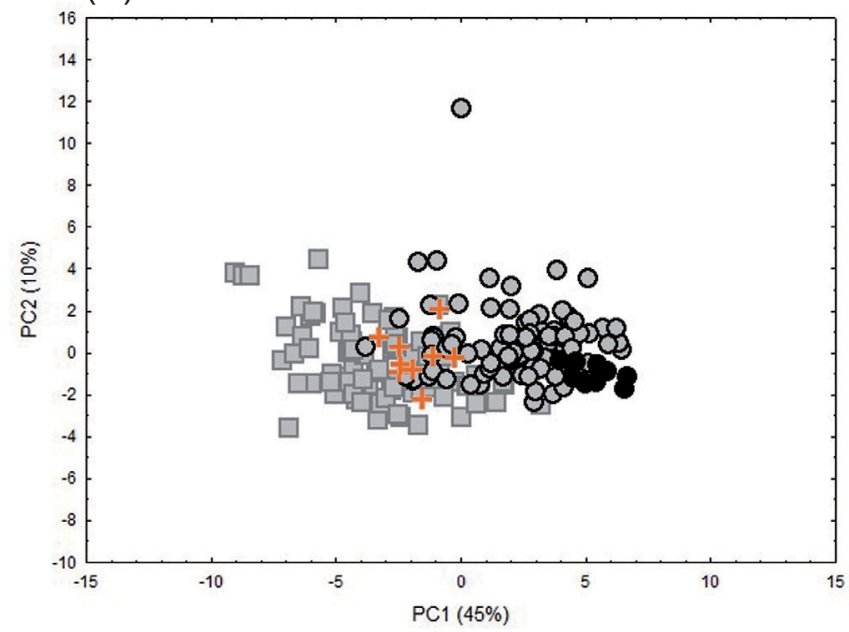

(B)

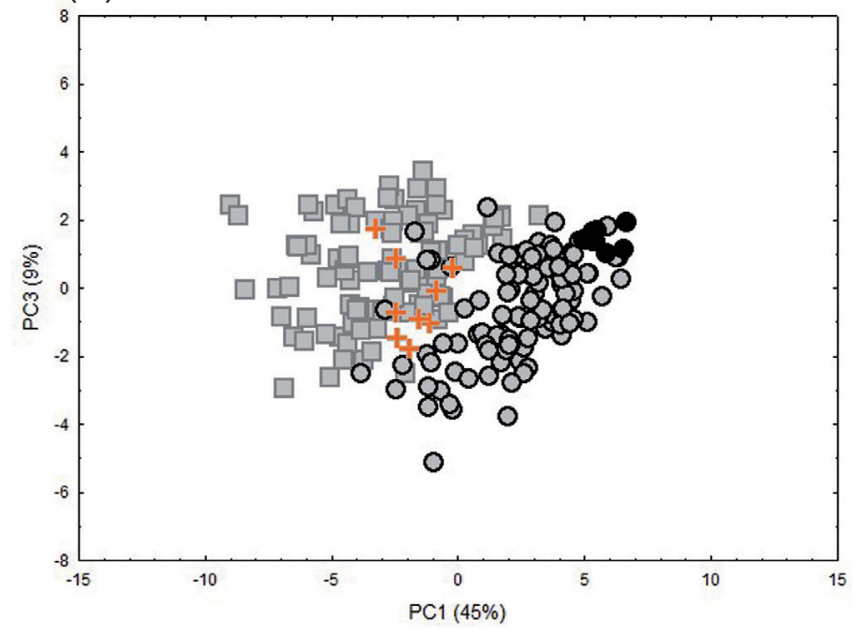

Fig. 7. Results of principal component analysis (PCA) for a reduced dataset (after exclusion of Carex flava, C. lepidocarpa, and their hybrids): (A) along axes PC1 and PC2; (B) along axes PC1 and PC3

Explanations: $\bigcirc-$ C. viridula var. viridula, - C. viridula var. pulchella, $\square-$ C. demissa, +- C. demissa $\times$ C. viridula. Loadings for the first axis (only absolute values $>0.50$ are given, characters abbreviated as in Table 2): $\mathrm{CH}=-0.72, \mathrm{CLW}=-0.71, \mathrm{C} / \mathrm{L}=0.59, \mathrm{IL}=-0.67, \mathrm{MSL}=-0.77, \mathrm{MPL}=-0.65, \mathrm{DLFS}$ $=-0.60, \mathrm{LFSL}=-0.75, \mathrm{LFSW}=-0.83, \mathrm{LBL}=-0.56, \mathrm{LBW}=-0.76, \mathrm{~B} / \mathrm{I}=0.54, \mathrm{UFSL}=-0.84, \mathrm{UFSW}=-0.86, \mathrm{SBL}=-0.67, \mathrm{SBW}=-0.75, \mathrm{UL}=-0.87, \mathrm{UBL}$ $=-0.87, \mathrm{~B} / \mathrm{U}=-0.70, \mathrm{FGL}=-0.83, \mathrm{FGW}=-0.67, \mathrm{MGL}=-0.77, \mathrm{MGW}=-0.64$. Loadings for the second axis: $\mathrm{IL}=0.50, \mathrm{NFS}=0.78, \mathrm{DLFS}=0.53, \mathrm{LPL}=$ $0.60, \mathrm{LBSL}=0.66$. Loadings for the third axis: $\mathrm{CLL}=-0.85, \mathrm{LBL}=-0.53, \mathrm{~B} / \mathrm{I}=-0.67$

groups. The first component is most strongly related to characters concerning utricle and beak size (UL, $\mathrm{UBL}$, and $\mathrm{B} / \mathrm{U}$ ) as well as dimensions of female spikes (LFSL, LFSW, UFSL, and UFSW) (Fig. 5). C. flava s.s. has the longest utricles and beaks, and the largest female spikes among members of the C. flava complex (in contrast to C. viridula) (Table 2). The second component distinguishes C. lepidocarpa from C. demissa and is associated with vegetative characters, especially dimensions of bracts (LBL, LBW, SBL, and SBW), culm height $(\mathrm{CH})$, male spike peduncle length (MPL), and number and arrangement of female spikes (NFS, DLFS) (Fig. 5A). C. lepidocarpa has relatively short and narrow bracts, long peduncles of male spikes, and usually 2 distant female spikes (Table 2). Along the third component, the most conspicuous division is visible between specimens of C. flava and C. lepidocarpa, resulting mostly from differences in inflorescence length (IL) and ratio of lowest female spike bract length to inflorescence length (B/I) (Fig. 5B;
(A)

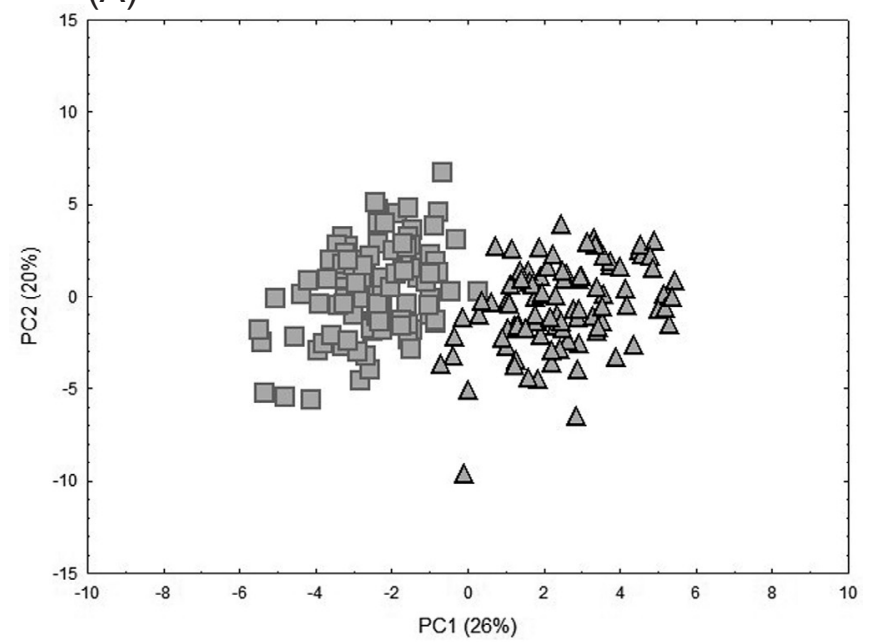

(B)

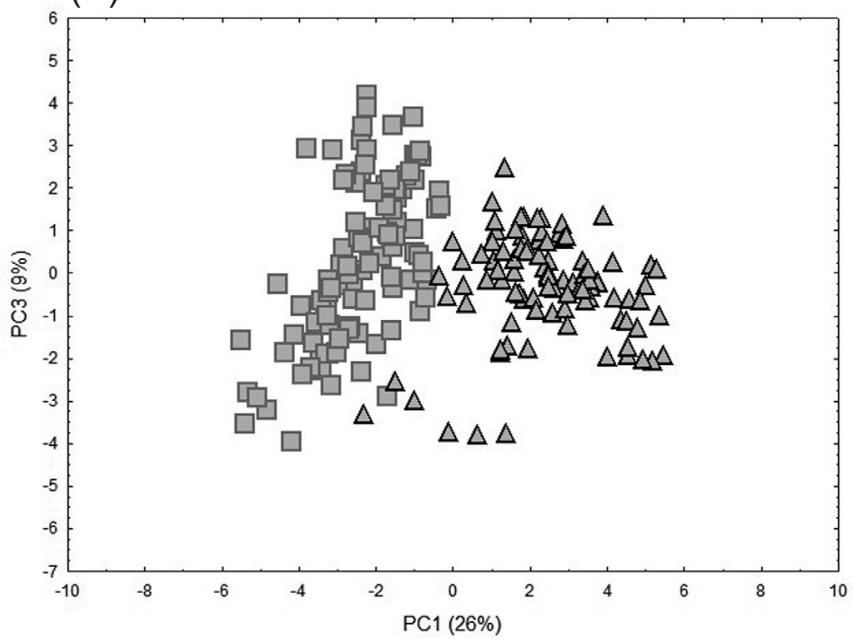

Fig. 8. Results of principal component analysis (PCA) for a reduced dataset (after exclusion of Carex flava, C. viridula, and their hybrids): (A) along axes PC1 and PC2; (B) along axes PC1 and PC3

Explanations: $\square-$ C. demissa, $\triangle-$ C. lepidocarpa. Loadings for the first axis (only absolute values $>0.50$ are given, characters abbreviated as in Table $2): \mathrm{CH}=0.72, \mathrm{IL}=-0.51, \mathrm{MPL}=0.64, \mathrm{NFS}=-0.85, \mathrm{DLFS}=-0.69, \mathrm{LFSW}=0.59, \mathrm{LBL}=-0.53, \mathrm{LBW}=-0.86, \mathrm{LBSL}=-0.56, \mathrm{SBL}=-0.79, \mathrm{SBW}=-0.89$, $\mathrm{B} / \mathrm{U}=-0.64$. Loadings for the second axis: $\mathrm{CLL}=-0.63, \mathrm{MSL}=-0.63, \mathrm{LFSL}=-0.70, \mathrm{LFSW}=-0.61, \mathrm{LFPL}=-0.58, \mathrm{LBL}=-0.66, \mathrm{UL}=-0.63, \mathrm{FGL}=-0.51$. Loadings for the third axis: $\mathrm{IL}=-0.65, \mathrm{DLFS}=-0.51, \mathrm{LBSL}=-0.53, \mathrm{~B} / \mathrm{I}=0.76$ 
Table 4. Results of discriminant analysis of taxa of the Carex flava group, presented as a matrix of classifications

\begin{tabular}{ccccccccccc}
\hline & \multicolumn{7}{c}{ Number and percentage of specimens classified into groups distinguished by DFA } \\
\cline { 2 - 11 } Taxon & $\mathrm{D}$ & $\mathrm{L}$ & $\mathrm{V}$ & $\mathrm{F}$ & $\mathrm{P}$ & $\mathrm{Sch}$ & $\mathrm{A}$ & $\mathrm{R}$ & $\mathrm{DxV}$ & Sub \\
\hline $\mathrm{D}$ & 98 & 0 & 0 & 0 & 0 & 0 & 0 & 0 & 2 & 0 \\
& $98.0 \%$ & 0 & 0 & 0 & 0 & 0 & 0 & 0 & $2.0 \%$ & 0 \\
$\mathrm{~L}$ & 0 & 97 & 0 & 0 & 0 & 1 & 0 & 2 & 0 & 0 \\
& 0 & $97.0 \%$ & 0 & 0 & 0 & $1.0 \%$ & 0 & $2.0 \%$ & 0 & 0 \\
$\mathrm{~V}$ & 1 & 0 & 94 & 0 & 4 & 0 & 0 & 0 & 1 & 0 \\
& $1.0 \%$ & 0 & $94.0 \%$ & 0 & $4.0 \%$ & 0 & 0 & 0 & $1.0 \%$ & 0 \\
$\mathrm{~F}$ & 0 & 0 & 0 & 98 & 0 & 0 & 2 & 0 & 0 & 0 \\
& 0 & 0 & 0 & $98.0 \%$ & 0 & 0 & $2.0 \%$ & 0 & 0 & 0 \\
$\mathrm{P}$ & 0 & 0 & 1 & 0 & 8 & 0 & 0 & 0 & 0 & 0 \\
& 0 & 0 & $11.1 \%$ & 0 & $88.9 \%$ & 0 & 0 & 0 & 0 & 0 \\
Sch & 0 & 2 & 2 & 0 & 0 & 27 & 0 & 0 & 0 & 0 \\
& 0 & $7.6 \%$ & $7.6 \%$ & 0 & 0 & $84.8 \%$ & 0 & 0 & 0 & 0 \\
$\mathrm{~A}$ & 0 & 0 & 0 & 1 & 0 & 0 & 51 & 0 & 0 & 0 \\
& 0 & 0 & 0 & $1.9 \%$ & 0 & 0 & $98.1 \%$ & 0 & 0 & 0 \\
$\mathrm{R}$ & 0 & 1 & 0 & 1 & 0 & 0 & 0 & 38 & 0 & 0 \\
& 0 & $2.5 \%$ & 0 & $2.5 \%$ & 0 & 0 & 0 & $95.0 \%$ & 0 & 0 \\
DxV & 1 & 0 & 1 & 0 & 0 & 0 & 0 & 0 & 7 & 0 \\
& $11.1 \%$ & 0 & $11.1 \%$ & 0 & 0 & 0 & 0 & 0 & $77.8 \%$ & 0 \\
& 1 & 0 & 1 & 1 & 0 & 0 & 0 & 0 & 0 & 15 \\
& $5.5 \%$ & 0 & $5.5 \%$ & $5.5 \%$ & 0 & 0 & 0 & 0 & 0 & $83.3 \%$ \\
\hline
\end{tabular}

Explanations: $\mathrm{A}-$ C. $\times$ alsatica, $\mathrm{D}-$ C. demiss, $\mathrm{D} \times \mathrm{V}-$ C. demiss $a \times$ C. viridula, $\mathrm{F}-$ C. flava s.s., $\mathrm{L}-$ C. lepidocarpa, $\mathrm{P}-$ C. viridula var. pulchella, $\mathrm{R}-$ C. $\times$ ruedtii, $\mathrm{Sch}-$ C. $\times$ schatzii, $\mathrm{Sub}-$ C. $\times$ subviridula, $\mathrm{V}-$ C. viridula var. viridula

Table 2). Distribution of specimens of C. viridula in the phenetic space is consistent with the results of Ward's hierarchical clustering, as specimens of C. viridula var. viridula and var. pulchella form one cluster (Figs. 1 and 5).

PCA conducted on a reduced data set (after exclusion of C. flava s.s. and its hybrids) shows morphological distinctness of specimens of $C$. viridula along the first axis, which is mostly affected by utricle length (UL) and beak length (UBL) (Fig. 6). The second component distinguishes $C$. lepidocarpa from $C$. demissa mostly on the basis of bract dimensions (LBL, LBW, SBL, and SBW), number of female spikes (NFS), and distance between 2 lowest female spikes (DLFS) (Fig. 6A). Along the third component, taxa are not segregated and form one cluster (Fig. 6B). Successive steps of PCA revealed that $(i) C$. demissa differs significantly from $C$. viridula in dimensions of utricles (UL, UBL, and $\mathrm{B} / \mathrm{U}$ ), glumes (FGL, FGW, MGL, and MGW), size and distribution of female spikes (LFSL, LFSW, UFSL, UFSW, IL, DLFS), length of male spikes and their peduncles (MSL and MPL), size of bracts and leaves (LBL, LBW, SBL, SBW, CLW, C/L), and culm height $(\mathrm{CH})$ (Fig. 7; Table 2), (ii) $C$. demissa differs significantly from $C$. lepidocarpa in dimensions of bracts (LBL, LBW, SBL, and SBW), ratio of beak length to utricle length $(B / U)$, number and arrangement of female spikes (NFS, DLFS,
IL), male spike length (MSL), and culm height (CH) (Fig. 8; Table 2).

Results of ANOVA indicate that the analysed species vary significantly in all the analysed characters $(p \leq$ 0.001 ) (Table 5). $F$ values are the highest for utricle and beak characters (UBL, B/U, UL), dimensions of female spikes (LFSL, LFSW, UFSL, and UFSW), culm height (CH), bract width (SBW and LBW), glume length (FGL and MGL), male spike peduncle length (MPL), and ratio of lowest female spike bract length to inflorescence length (B/I) (Table 5). The post hoc Spjotvoll/Stoline test detected no significant differences between varieties of C. viridula (var. viridula and var. pulchella), except for cauline leaf length (CLL), number of female spikes (NFS), lowest female spike bract length (LBL), and utricle length (UL). The other taxa differ significantly $(p \leq 0.001)$ in culm height $(\mathrm{CH})$, width of female spikes (UFSW and LFSW), utricle length (UL), and ratio of beak length to utricle length (B/U) (Table 5). The longest utricles and widest female spikes are found in specimens of $C$. flava, the shortest beaks are in C. viridula, the highest ratio of beak length to utricle length is in $C$. demissa, whereas the longest culms, narrowest bracts and longest male spike peduncles are in C. lepidocarpa (Fig. 9; Table 2).

In delimitation of taxa from the C. flava group, a significant role is played primarily by the length of 

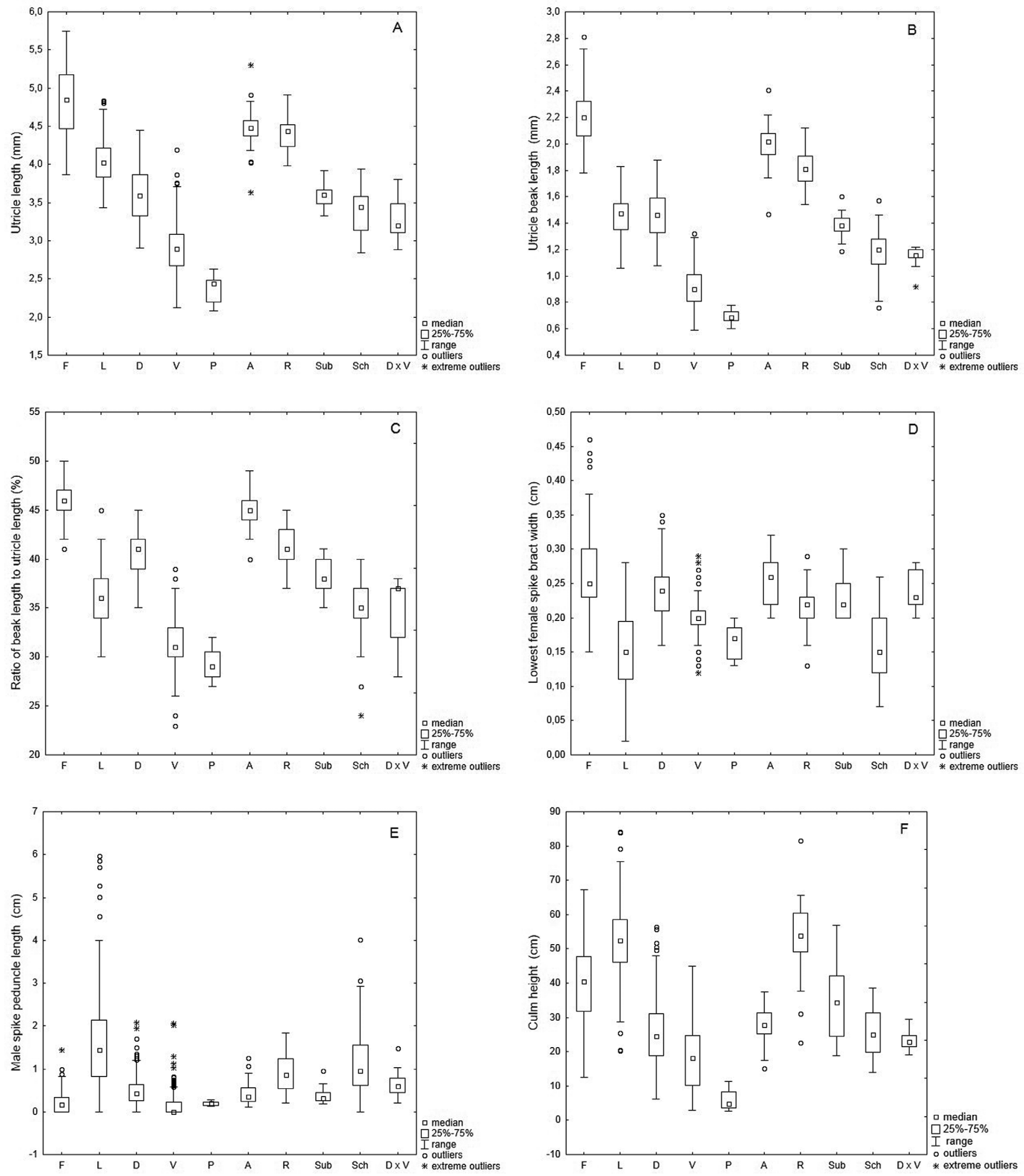

Fig. 9. Comparison of dimensions of selected morphological characters of taxa and hybrids of the Carex flava group.

Explanations: $\mathrm{A}-$ C. $\times$ alsatica, $\mathrm{D}-$ C. demissa, $\mathrm{D} \times \mathrm{V}-$ C. demissa $\times$ C. viridula, $\mathrm{F}-$ C. flava s.s., $\mathrm{L}-$ C. lepidocarpa, $\mathrm{P}-$ C. viridula var. pulchella, $\mathrm{R}-$ C. $\times$ ruedtii, $\mathrm{Sch}-$ C. $\times$ schatzii, $\mathrm{Sub}-$ C. $\times$ subviridula, $\mathrm{V}-$ C. viridula

utricle and its beak. The mean length of utricle and beak declines in the following order: C. Alava, C. lepidocarpa, C. demissa, C. viridula var. viridula, and C. viridula var. pulchella (Fig. 9A-B; Appendix 3). The ratio of beak length to total utricle length $(\mathrm{B} / \mathrm{U})$ is also characteristic of the analysed taxa and its value declines from C. flava to $C$. viridula in a similar order, except $C$. demissa, $\mathrm{B} / \mathrm{U}$ $=40 \%$, and C.lepidocarpa, $\mathrm{B} / \mathrm{U}=36 \%$, whose sequence is reverse) (Fig. 9C).

In summary, statistical analyses show clear (especially in DFA) morphological differences between species of the $C$. flava complex. Only $C$. viridula includes 
Table 5. Results of one-way analysis of variance (ANOVA) and the post hoc Tukey HSD test for unequal $N$ (Spjotvoll/Stoline test), showing significance of differences in morphological characters of taxa of the Carex flava group

\begin{tabular}{|c|c|c|c|c|c|c|c|c|c|c|c|c|}
\hline \multirow[b]{3}{*}{ Character } & \multirow{2}{*}{\multicolumn{2}{|c|}{ ANOVA }} & \multicolumn{10}{|c|}{ Post hoc Spjotvoll/Stoline test } \\
\hline & & & F-L & F-D & F-V & F-P & L-D & $\mathrm{L}-\mathrm{V}$ & L-P & $\mathrm{D}-\mathrm{V}$ & D-P & V-P \\
\hline & $F$ & $p$ & $p$ & $p$ & $p$ & $p$ & $p$ & $p$ & $p$ & $p$ & $p$ & $p$ \\
\hline $\mathrm{CH}$ & 373.69 & $* * *$ & $* * *$ & $* * *$ & $* * *$ & $* * *$ & $* * *$ & $* * *$ & $* * *$ & $* * *$ & $* * *$ & ns \\
\hline CLW & 158.09 & $* * *$ & $* * *$ & $* * *$ & $* * *$ & $* * *$ & $* *$ & $* * *$ & $*$ & $* * *$ & $* * *$ & ns \\
\hline CLL & 120.15 & $* * *$ & $* * *$ & $* * *$ & $* * *$ & $* * *$ & $* * *$ & ns & $* * *$ & $* * *$ & ns & $* *$ \\
\hline $\mathrm{C} / \mathrm{L}$ & 138.96 & $* * *$ & $* * *$ & $* * *$ & $*$ & $\mathrm{~ns}$ & $\mathrm{~ns}$ & $* * *$ & $* * *$ & $* * *$ & $* * *$ & ns \\
\hline IL & 51.61 & $* * *$ & $* * *$ & $* * *$ & $\mathrm{~ns}$ & $\mathrm{~ns}$ & $* * *$ & $* * *$ & $\mathrm{~ns}$ & $* * *$ & $* *$ & ns \\
\hline MSL & 111.78 & $* * *$ & $* * *$ & $\mathrm{~ns}$ & $* * *$ & $* *$ & $* * *$ & $* * *$ & $* * *$ & $* * *$ & $*$ & ns \\
\hline MSW & 40.69 & $* * *$ & $* * *$ & $*$ & $* *$ & $\mathrm{~ns}$ & $* * *$ & $* * *$ & $\mathrm{~ns}$ & $\mathrm{~ns}$ & $\mathrm{~ns}$ & $\mathrm{~ns}$ \\
\hline MPL & 226.37 & $* * *$ & $* * *$ & $* *$ & $\mathrm{~ns}$ & $\mathrm{~ns}$ & $* * *$ & $* * *$ & $* * *$ & $* * *$ & $\mathrm{~ns}$ & ns \\
\hline NFS & 123.97 & $* * *$ & $* * *$ & $* * *$ & $* * *$ & $\mathrm{~ns}$ & $* * *$ & $* * *$ & $\mathrm{~ns}$ & $* * *$ & $\mathrm{~ns}$ & $* *$ \\
\hline DUFS & 111.12 & $* * *$ & $* * *$ & $\mathrm{~ns}$ & $*$ & ns & $* * *$ & $* * *$ & $* * *$ & $* *$ & $\mathrm{~ns}$ & ns \\
\hline DLFS & 38.76 & $* * *$ & $*$ & $* * *$ & $\mathrm{~ns}$ & ns & $\mathrm{ns}$ & $\mathrm{ns}$ & ns & $* * *$ & $\mathrm{~ns}$ & $\mathrm{~ns}$ \\
\hline LFSL & 201.69 & $* * *$ & $\mathrm{~ns}$ & $* * *$ & $* * *$ & $* * *$ & $* * *$ & $* * *$ & $* * *$ & $* * *$ & $* * *$ & ns \\
\hline LFSW & 656.35 & $* * *$ & $* * *$ & $* * *$ & $* * *$ & $* * *$ & $* * *$ & $* * *$ & $* * *$ & $* * *$ & $* * *$ & $\mathrm{~ns}$ \\
\hline LPL & 10.24 & $* * *$ & $\mathrm{~ns}$ & $\mathrm{~ns}$ & $* * *$ & $\mathrm{~ns}$ & $\mathrm{~ns}$ & $* * *$ & $\mathrm{~ns}$ & $* *$ & ns & ns \\
\hline LBL & 49.47 & $* * *$ & $* * *$ & $* * *$ & $* * *$ & $* * *$ & $* * *$ & $* * *$ & $\mathrm{~ns}$ & $\mathrm{~ns}$ & $*$ & $*$ \\
\hline LBW & 164.60 & $* * *$ & $* * *$ & $* * *$ & $* * *$ & $* * *$ & $* * *$ & $* * *$ & $\mathrm{~ns}$ & $* * *$ & $* *$ & ns \\
\hline LBSL & 11.94 & $* * *$ & $\mathrm{~ns}$ & $* * *$ & $\mathrm{~ns}$ & $\mathrm{~ns}$ & $* * *$ & $\mathrm{~ns}$ & $\mathrm{~ns}$ & $* * *$ & $\mathrm{~ns}$ & $\mathrm{~ns}$ \\
\hline $\mathrm{B} / \mathrm{I}$ & 170.37 & $* * *$ & $* * *$ & $* * *$ & $* *$ & $\mathrm{~ns}$ & $\mathrm{~ns}$ & $* * *$ & $\mathrm{~ns}$ & $* * *$ & $\mathrm{~ns}$ & ns \\
\hline UFSL & 328.18 & $* * *$ & $\mathrm{~ns}$ & $* * *$ & $* * *$ & $* * *$ & $* * *$ & $* * *$ & $* * *$ & $* * *$ & $* *$ & ns \\
\hline UFSW & 639.74 & $* * *$ & $* * *$ & $* * *$ & $* * *$ & $* * *$ & $* * *$ & $* * *$ & $* * *$ & $* * *$ & $* * *$ & ns \\
\hline SBL & 86.86 & $* * *$ & $* * *$ & $* * *$ & $* * *$ & $* * *$ & $* * *$ & $* *$ & $\mathrm{~ns}$ & $* * *$ & $* * *$ & ns \\
\hline SBW & 230.48 & $* * *$ & $* * *$ & $\mathrm{~ns}$ & $* * *$ & $* * *$ & $* * *$ & $* * *$ & $\mathrm{~ns}$ & $* * *$ & $* * *$ & ns \\
\hline UL & 757.29 & $* * *$ & $* * *$ & $* * *$ & $* * *$ & $* * *$ & $* * *$ & $* * *$ & $* * *$ & $* * *$ & $* * *$ & $*$ \\
\hline UBL & 1458.16 & $* * *$ & $* * *$ & $* * *$ & $* * *$ & $* * *$ & $\mathrm{~ns}$ & $* * *$ & $* * *$ & $* * *$ & $* * *$ & ns \\
\hline $\mathrm{B} / \mathrm{U}$ & 866.57 & $* * *$ & $* * *$ & $* * *$ & $* * *$ & $* * *$ & $* * *$ & $* * *$ & $* * *$ & $* * *$ & $* * *$ & ns \\
\hline FGL & 219.14 & $* * *$ & $* * *$ & $* * *$ & $* * *$ & $* * *$ & ns & $* * *$ & $* * *$ & $* * *$ & $* * *$ & ns \\
\hline FGW & 72.47 & $* * *$ & $\mathrm{~ns}$ & $\mathrm{~ns}$ & $* * *$ & $*$ & $\mathrm{~ns}$ & $* * *$ & $\mathrm{~ns}$ & $* * *$ & ns & ns \\
\hline MGL & 179.24 & $* * *$ & $\mathrm{~ns}$ & $* * *$ & $* * *$ & $* *$ & $* * *$ & $* * *$ & $*$ & $* * *$ & $* * *$ & ns \\
\hline MGW & 82.36 & $* * *$ & $* * *$ & $* * *$ & $\mathrm{~ns}$ & ns & $\mathrm{ns}$ & $* * *$ & ns & $* * *$ & $\mathrm{~ns}$ & ns \\
\hline
\end{tabular}

Explanations: $\mathrm{D}-$ C. demissa, $\mathrm{F}-$ C. flava s.s., $\mathrm{L}-$ C. lepidocarpa, $\mathrm{P}-$ C. viridula var. pulchella, $\mathrm{V}-$ C. viridula var. viridula, $F-$ value of $F$ test, ns - nonsignificant, $p$ - significance level, ${ }^{*} p \leq 0.05, * * p \leq 0.01,{ }^{* * *} p \leq 0.001$. Characters abbreviated as in Table 1

2 varieties; one of them, var. pulchella, was earlier regarded as a separate species or subspecies within C. viridula agg. (see Chater 1980; Schmid 1983; Pykälä \& Toivonen 1994; Egorova 1999; Hedrén 2003; Koopman 2011).

\subsection{Hybrids within the Carex flava agg.}

Hybrids formed spontaneously within the C. flava group are completely sterile or may be partly fertile and backcross with either of the parental species. The performed classification of OTUs assigned hybrids to separate subgroups $\left(\mathrm{A}_{2}, \mathrm{~B}_{2}, \mathrm{C}_{2}, \mathrm{C}_{3}\right.$, and $\left.\mathrm{D}_{2}\right)$ within clusters corresponding to pure species (A, B, C, D) (Fig. 1). Hybrids are morphologically intermediate between the parental taxa or they resemble more closely either of them. Thus cluster analysis indicated which putative parent is more similar to the hybrids in respect of the analysed characters (Fig. 1).
Relations between hybrids and parental taxa are reflected in their distribution in the phenetic space, which is consistent with results of the classification presented in the phenogram (Fig. 1). Distribution of OTUs along the first 3 PCA and DFA axes shows the morphologically intermediate position of hybrids in relation to parents or indicates the parent to which the hybrids are most similar, but PCA separated them less clearly than DFA did (Figs. 2-3). In DFA, phenetic distinctness of hybrids is well-defined, as $77.8-98.1 \%$ of OTUs were classified properly (Table 4).

Specimens of $C$. $\times$ alsatica are located close to specimens of $C$. flava, which indicates their high phenetic similarity (Fig. 2). Specimens of $C$. xruedtii fill the space between $C$. flava and C. lepidocarpa, but some hybrids are closer to $C$. lepidocarpa. Specimens of $C$. $\times$ schatzii are morphologically intermediate between C. lepidocarpa and C. viridula, or more similar to one 
Table 6. Results of one-way analysis of variance (ANOVA) and the post hoc Tukey HSD test for unequal $N$ (Spjotvoll/Stoline test), showing significance of differences in morphological characters of hybrids of the Carex flava group

\begin{tabular}{|c|c|c|c|c|c|c|c|c|c|c|c|c|}
\hline \multirow{3}{*}{ Character } & \multirow{2}{*}{\multicolumn{2}{|c|}{ ANOVA }} & \multicolumn{10}{|c|}{ Post hoc Spjotvoll/Stoline test } \\
\hline & & & A-R & A-Sch & A-DxV & A-Sub & R-Sch & $\mathrm{R}-\mathrm{DxV}$ & R-Sub & Sch-DxV & Sch-Sub & DxV-Sub \\
\hline & $F$ & $p$ & $p$ & $p$ & $p$ & $p$ & $p$ & $p$ & $p$ & $p$ & $p$ & $p$ \\
\hline $\mathrm{CH}$ & 79.24 & $* * *$ & $* * *$ & $\mathrm{~ns}$ & ns & ns & $* * *$ & $* * *$ & $* * *$ & ns & $* *$ & $*$ \\
\hline CLW & 13.22 & $* * *$ & ns & $* * *$ & $*$ & $* *$ & $* *$ & $\mathrm{~ns}$ & $\mathrm{~ns}$ & ns & ns & ns \\
\hline CLL & 18.72 & $* * *$ & ns & $* * *$ & ns & ns & $* * *$ & $*$ & ns & ns & $* * *$ & ns \\
\hline $\mathrm{C} / \mathrm{L}$ & 6.95 & $* * *$ & ns & $* *$ & $\mathrm{~ns}$ & ns & $* * *$ & ns & ns & ns & $* *$ & ns \\
\hline IL & 2.38 & $\mathrm{~ns}$ & $\mathrm{~ns}$ & $\mathrm{~ns}$ & $\mathrm{~ns}$ & ns & $\mathrm{ns}$ & ns & $\mathrm{ns}$ & ns & ns & ns \\
\hline MSL & 6.76 & $* * *$ & ns & $* *$ & ns & ns & $* *$ & ns & ns & ns & ns & ns \\
\hline MSW & 9.29 & $* * *$ & $\mathrm{~ns}$ & $* * *$ & $\mathrm{~ns}$ & ns & $*$ & ns & ns & $\mathrm{ns}$ & $* * *$ & $\mathrm{~ns}$ \\
\hline MPL & 17.33 & $* * *$ & $* * *$ & $* * *$ & ns & ns & ns & ns & $* *$ & ns & $* * *$ & ns \\
\hline NFS & 13.51 & $* * *$ & $* *$ & $* * *$ & $\mathrm{~ns}$ & ns & ns & ns & $* *$ & $* *$ & $* * *$ & ns \\
\hline DUFS & 10.09 & $* * *$ & $\mathrm{~ns}$ & $* * *$ & ns & ns & $* *$ & ns & $\mathrm{ns}$ & $\mathrm{ns}$ & $* * *$ & $\mathrm{~ns}$ \\
\hline DLFS & 6.40 & $* * *$ & $* *$ & $* *$ & ns & ns & $\mathrm{ns}$ & $*$ & $\mathrm{~ns}$ & $* *$ & $\mathrm{~ns}$ & $\mathrm{~ns}$ \\
\hline LFSL & 16.97 & $* * *$ & ns & $* * *$ & $\mathrm{~ns}$ & $*$ & $* * *$ & $* *$ & $* * *$ & ns & ns & $\mathrm{ns}$ \\
\hline LFSW & 105.15 & $* * *$ & $\mathrm{~ns}$ & $* * *$ & $* * *$ & $* * *$ & $* * *$ & $* * *$ & $* * *$ & $* *$ & $\mathrm{~ns}$ & $* *$ \\
\hline LPL & 2.11 & $\mathrm{~ns}$ & $\mathrm{~ns}$ & $\mathrm{~ns}$ & ns & $\mathrm{ns}$ & $\mathrm{ns}$ & $\mathrm{ns}$ & $\mathrm{ns}$ & $\mathrm{ns}$ & ns & $\mathrm{ns}$ \\
\hline LBL & 10.04 & $* * *$ & $* *$ & $* * *$ & $\mathrm{~ns}$ & ns & ns & ns & ns & $\mathrm{ns}$ & $* *$ & ns \\
\hline LBW & 36.18 & $* * *$ & $* * *$ & $* * *$ & $\mathrm{~ns}$ & ns & $* * *$ & ns & ns & $* * *$ & $* * *$ & $\mathrm{~ns}$ \\
\hline LBSL & 7.86 & $* * *$ & $* * *$ & $\mathrm{~ns}$ & $\mathrm{~ns}$ & ns & $* * *$ & $*$ & ns & $\mathrm{ns}$ & $\mathrm{ns}$ & $\mathrm{ns}$ \\
\hline $\mathrm{B} / \mathrm{I}$ & 21.01 & $* * *$ & ns & $* * *$ & $\mathrm{~ns}$ & ns & $* * *$ & ns & ns & ns & $* * *$ & $* *$ \\
\hline UFSL & 15.00 & $* * *$ & ns & $* * *$ & $\mathrm{~ns}$ & $*$ & $* * *$ & ns & $* *$ & $\mathrm{~ns}$ & $\mathrm{~ns}$ & $\mathrm{~ns}$ \\
\hline UFSW & 22.51 & $* * *$ & $\mathrm{~ns}$ & $* * *$ & $\mathrm{~ns}$ & ns & $* * *$ & $* *$ & $* *$ & $\mathrm{~ns}$ & $\mathrm{~ns}$ & $\mathrm{~ns}$ \\
\hline SBL & 33.32 & $* * *$ & $* * *$ & $* * *$ & $\mathrm{~ns}$ & ns & $\mathrm{ns}$ & $*$ & $* * *$ & $* * *$ & $* * *$ & ns \\
\hline SBW & 67.29 & $* * *$ & $* * *$ & $* * *$ & ns & $\mathrm{ns}$ & $* * *$ & $* * *$ & $* * *$ & $* * *$ & $* * *$ & $\mathrm{~ns}$ \\
\hline UL & 156.26 & $* * *$ & $\mathrm{~ns}$ & $* * *$ & $* * *$ & $* * *$ & $* * *$ & $* * *$ & $* * *$ & $\mathrm{~ns}$ & $\mathrm{~ns}$ & $\mathrm{~ns}$ \\
\hline UBL & 215.99 & $* * *$ & $* * *$ & $* * *$ & $* * *$ & $* * *$ & $* * *$ & $* * *$ & $* * *$ & ns & $* * *$ & $* *$ \\
\hline $\mathrm{B} / \mathrm{U}$ & 107.19 & $* * *$ & $* * *$ & $* * *$ & $* * *$ & $* * *$ & $* * *$ & $* * *$ & $*$ & $\mathrm{~ns}$ & $* * *$ & $* *$ \\
\hline FGL & 41.33 & $* * *$ & $* * *$ & $* * *$ & $* * *$ & $* * *$ & $* * *$ & $\mathrm{~ns}$ & ns & ns & $\mathrm{ns}$ & ns \\
\hline FGW & 8.82 & $* * *$ & $*$ & $\mathrm{~ns}$ & $\mathrm{~ns}$ & $* * *$ & $\mathrm{~ns}$ & ns & ns & ns & $*$ & $*$ \\
\hline MGL & 20.55 & $* * *$ & $\mathrm{~ns}$ & $* * *$ & $\mathrm{~ns}$ & $\mathrm{~ns}$ & $* * *$ & ns & ns & ns & ns & ns \\
\hline MGW & 5.53 & $* * *$ & $* *$ & $* *$ & $\mathrm{~ns}$ & ns & $\mathrm{ns}$ & ns & ns & ns & ns & $\mathrm{ns}$ \\
\hline
\end{tabular}

Explanations: A $-C . \times$ alsatica, $\mathrm{D} \times \mathrm{V}-C$. demissa $\times C$. viridula, $\mathrm{R}-C . \times$ ruedtii, $\mathrm{Sch}-C . \times$ schatzii, Sub $-C . \times$ subviridula, $F-$ value of $F$ test, ns - nonsignificant, $p$ - significance level, $* p \leq 0.05, * * p \leq 0.01, * * * p \leq 0.001$. Characters abbreviated as in Table 1

parent, usually to C. lepidocarpa. Specimens of $C$. $\times$ subviridula in the DFA space along the first 2 axes cover the area between $C$. viridula and C. flava, and overlap with a group of specimens of $C$. demissa (Fig. 2). In that case, the classification of OTUs is inconsistent with their distribution in the DFA space. In cluster analysis, specimens of $C$. ×subviridula are located in cluster B, dominated by specimens of $C$. viridula. This situation probably results from morphological similarity of $C$. viridula, C. demissa, and this hybrid, especially in utricle dimensions, but all specimens of $C$. $\times$ subviridula are completely sterile. For the hybrid $C$. demissa $\times C$. viridula, also a slight inconsistency was observed between this classification and distribution of OTUs. In the phenogram, hybrids form one cluster with C. demissa, whereas in one of the scatterplots they are grouped with $C$. viridula, and in the other one, with $C$. demissa (Fig. 2). However, the phenetic distinctness of hybrids is quite clear in DFA, as the percentage of properly classified specimens reached $77.8 \%$ for $C$. demissa $\times$ C. viridula and $83.3 \%$ for C. $\times$ subviridula. Several specimens of hybrids were classified by DFA to clusters of putative parents, e.g.: one specimen of $C$. demissa $\times$ $C$. viridula was grouped with $C$. demissa, while another, with $C$. viridula (Table 4).

Hybrids vary significantly in nearly all the analysed morphological characters (ANOVA, $p \leq 0.001$ ) (Table 6). The greatest variation was observed in utricle characters (UBL, UL, and B/U), lowest female spike width (LFSW), culm height (CH), and second female spike bract width (SBW), whose $F$ values exceeded 50 (Table 6). The post hoc Spjotvoll/Stoline test revealed the largest number of significant differences between C. $\times$ alsatica $[$ C. flava $\times$ C. lepidocarpa $]$ and C. $\times$ schatzii $[C$. lepidocarpa $\times C$. viridula $]$, while the smallest number of differences was between $C$. $\times$ schatzii and $C$. 
Table 7. Variation of morphological characters of hybrids of the Carex flava group

\begin{tabular}{|c|c|c|c|c|c|c|c|c|c|c|c|c|c|c|c|c|c|c|c|c|}
\hline \multirow[b]{2}{*}{ Character } & \multicolumn{5}{|c|}{ C. $\times$ alsatica } & \multicolumn{5}{|c|}{ C. $\times$ ruedtii } & \multicolumn{5}{|c|}{ C. $\times$ schatzii } & \multicolumn{5}{|c|}{ C. demissa $\times$ C. viridula } \\
\hline & $x$ & $\min$ & $\max$ & SD & $V$ & $x$ & $\min$ & $\max$ & SD & $V$ & $x$ & $\min$ & $\max$ & $\mathrm{SD}$ & $V$ & $x$ & $\min$ & $\max$ & SD & $V$ \\
\hline $\mathrm{CH}$ & 28.0 & 15.2 & 37.5 & 5.29 & 19 & 53.2 & 22.7 & 81.6 & & 19 & 25.7 & 13.9 & & & 27 & 23.7 & 19.1 & 29.4 & & 14 \\
\hline & 0.3 & 0.2 & & .03 & 12 & & 0.2 & 0.4 & & 14 & & 0.2 & 0.3 & 0.04 & 15 & 0.2 & 0.2 & 0.3 & 0.01 & 6 \\
\hline CLL & 13.1 & 6.3 & 19.7 & 3.79 & 29 & 14.8 & 8.7 & 23.1 & & 22 & 7.8 & 3.7 & 20.1 & 4.43 & & & 7.7 & 12.4 & 1.57 & 16 \\
\hline $\mathrm{C} / \mathrm{L}$ & 2 & 1 & 3 & 0.54 & 29 & 2 & 1 & 3 & 0.47 & 24 & 1 & 1 & 4 & 0.72 & 52 & 2 & 1 & 2 & 0.53 & 34 \\
\hline IL & 6.1 & 2.5 & 21.6 & 3.93 & 65 & 4.9 & 2.9 & 9.7 & 1.35 & 28 & 5.6 & 2.6 & 12.2 & 2.64 & 47 & 8.0 & 4.6 & 16.4 & 4.11 & 51 \\
\hline & & 1.0 & 2.2 & 0.28 & 16 & 1. & 0.5 & 2.6 & 0.3 & 21 & 1. & 1.0 & 1.9 & 0.24 & 1 & 1.7 & & 2.0 & 0.20 & 12 \\
\hline MSV & 0.2 & 0.1 & 0.2 & 0.02 & 11 & 0. & 0.1 & 0.2 & & 11 & 0 & 0.1 & 0. & 0.03 & & 0 & & .2 & 0.01 & 9 \\
\hline MPL & 0.4 & 0.0 & 1.3 & 0.26 & 63 & 0.9 & 0.0 & 1.8 & 0.4 & 52 & 1.3 & 0.0 & 4.0 & 0.9 & & 0.7 & & 1.5 & 0.38 & 56 \\
\hline NFS & 3 & 2 & 4 & 0.58 & 20 & 2 & 1 & 3 & & 2 & 2 & 1 & 4 & 0. & & 3 & 2 & 4 & 0.5 & 17 \\
\hline DU & 0.7 & 0.2 & 1.7 & 0.32 & 45 & 1 & 0.0 & 2.2 & & 40 & 2.2 & 0.3 & 7.0 & 1.8 & & 0 & & 1.2 & 0.24 & 32 \\
\hline DLFS & 4. & 1.1 & 17.2 & 3.84 & 94 & 2 & 1.1 & 4.5 & & 42 & & 2.6 & 7.1 & 1.8 & & & 0 & 13.2 & 4.23 & 90 \\
\hline LFSL & 1.3 & 0.9 & 1.6 & 0.16 & 13 & 1. & 1.1 & 1. & 0.10 & 8 & 1. & 0.9 & 1.4 & 0.1 & 12 & 1.1 & & 1.3 & 0.09 & 8 \\
\hline LFSW & 0 . & 0.7 & & 0.05 & 6 & 0 & 0.8 & & & 6 & & & 0.8 & 0.06 & 8 & & & 0.7 & 0.06 & 10 \\
\hline LPL & 0.3 & 0.0 & 0.9 & 0.28 & 95 & 0.2 & 0.0 & 1.3 & 0.28 & 128 & 0. & 0.0 & 3.2 & 0.68 & 149 & 0.1 & & 0.6 & 0.19 & 148 \\
\hline LBL & 11.0 & 3.4 & 19.9 & & 39 & & 3.9 & 15.9 & & & & 1.8 & 21.7 & 4.36 & & & & 11.1 & 1. & 11 \\
\hline LBW & 0.3 & 0.2 & 0 & 0.03 & 13 & 0.2 & 0.1 & 0.3 & 0.03 & 1 & 0.2 & 0.1 & 0.3 & 0.05 & 32 & 0.2 & & 0.3 & 0.03 & 12 \\
\hline LBSL & 0.9 & 0.2 & 2.8 & 0.71 & 80 & 0.3 & 0.1 & & & & & 0.1 & 3.0 & 0.7 & & & & 2.0 & 0.52 & 44 \\
\hline B/I & 3 & 1 & 4 & 0.63 & 20 & 3 & 2 & 4 & 0.27 & 9 & 2 & 1 & 4 & 0.87 & 43 & 2 & 1 & 3 & 0.88 & 36 \\
\hline UFSL & 1.1 & 0.7 & 1.4 & 0.15 & 14 & 1.2 & 1.0 & & & 9 & & & 1.3 & & & & & 1.0 & 0.10 & 11 \\
\hline UFSW & 0.8 & 0.6 & 1.0 & 0.06 & 7 & 0.9 & 0.7 & 0.9 & 0.0 & 5 & 0.7 & 0.6 & 0.8 & 0.06 & 9 & 0.6 & 0.6 & 0.7 & 0.03 & 5 \\
\hline SBL & 5.2 & 2.2 & 9.6 & & 33 & 2. & 0.5 & 5 & & & & 0.6 & 5.4 & 1.54 & 89 & 5.1 & & 4.8 & 0.65 & 13 \\
\hline SBW & 0.2 & 0.1 & 0.2 & 0.03 & 17 & 0.1 & 0.0 & 0.2 & 0.04 & 48 & 0.1 & 0.0 & 0.1 & 0.03 & 49 & 0.2 & 0.1 & 0.2 & 0.02 & 16 \\
\hline UL & 4.5 & 3.6 & 5.3 & 0.24 & 5 & 4.4 & 4.0 & 4.9 & 0.2 & 5 & & 2.8 & 3.9 & 0.29 & 8 & 3.3 & 2.9 & 3.8 & 0.30 & 9 \\
\hline UBL & 2.0 & 1.5 & 2.4 & 0.14 & 7 & 1.8 & 1.5 & 2.1 & 0.14 & 8 & 1.2 & 0.8 & 1.6 & 0.19 & 16 & 1.1 & 0.9 & 1.2 & 0.09 & 8 \\
\hline $\mathrm{B} / \mathrm{U}$ & 45 & 40 & 49 & 1.57 & 3 & 41 & 37 & 45.0 & 2.01 & 5 & 35 & 24 & 40 & 3.49 & 10 & 35 & 28 & 38 & 3.61 & 10 \\
\hline FGL & 2.9 & 2.4 & 3.5 & 0.20 & 7 & 2.6 & 1.7 & 3.1 & 0.19 & 7 & 2.4 & 2.0 & 2.9 & 0.23 & 10 & 2.5 & 2.3 & 2.8 & 0.12 & 5 \\
\hline FGW & 1.6 & 1.3 & 1.8 & 0.12 & 8 & 1.5 & 1.2 & 1.7 & 0.09 & 6 & 1. & 1.2 & 1.8 & 0.14 & 10 & 1.6 & 1.3 & 1.8 & 0.13 & 8 \\
\hline MGL & 3.7 & 3.1 & 4.1 & 0.21 & 6 & 3.6 & 3.4 & 4.5 & 0.20 & 5 & 3.3 & 2.8 & 3.9 & 0.27 & 8 & 3.5 & 3.3 & 3.6 & 0.11 & 3 \\
\hline MGW & 1.6 & 1.3 & 1.9 & 0.16 & 10 & 1.7 & 1.3 & 2.3 & 0.18 & 11 & 1.7 & 1.4 & 2.0 & 0.16 & 10 & 1.6 & 1.5 & 1.7 & 0.09 & 5 \\
\hline
\end{tabular}

Explanations: $x$ - arithmetic mean, min and max - minimum and maximum values, $\mathrm{SD}$ - standard deviation, $V$ - coefficient of variation for individual hybrid. Characters abbreviated as in Table 1

demissa $\times C$. viridula, and between $C$. $\times$ subviridula $[C$. flava $\times$ C. viridula] and C. demissa $\times$ C. viridula (Table 6).

In the delimitation of hybrids from the C. flava group, as in the case of pure species, a significant role is played by the length of utricle and its beak (Appendix 2). These characters are morphologically the least variable and can be used effectively to distinguish among hybrids and between hybrids and their putative parents (Tables 2

Table 8. Values of soil parameters at sites of taxa of the Carex flava group

\begin{tabular}{|c|c|c|c|c|c|c|c|c|}
\hline \multirow{2}{*}{ Soil parameters } & \multicolumn{8}{|c|}{ Taxon } \\
\hline & $x$ & $\min -\max$ & $x$ & $\min -\max$ & $x$ & $\min -\max$ & $x$ & $\min -\max$ \\
\hline $\mathrm{C}(\%)$ & 14.4 & $1.7-39.7$ & 25.4 & $11.6-40.7$ & 8.7 & $1.7-37.5$ & 10.4 & $0.03-40.7$ \\
\hline $\mathrm{N}(\%)$ & 1.1 & $0.1-3.01$ & 1.6 & $0.21-3.0$ & 0.6 & $0.1-2.9$ & 0.6 & $0.01-2.8$ \\
\hline Org. mat. (\%) & 25.1 & $2.9-68.5$ & 36.8 & $0.0-64.2$ & 15.1 & $2.9-64.6$ & 14.8 & $0.0-64.2$ \\
\hline $\mathrm{K}\left(\mathrm{mg} \cdot \mathrm{kg}^{-1}\right)$ & 93.3 & $21.4-250.1$ & 68.7 & $16.9-318.9$ & 123.0 & $7.9-250.1$ & 57.7 & $16.2-244.6$ \\
\hline $\operatorname{Mg}\left(\mathrm{mg} \cdot \mathrm{kg}^{-1}\right)$ & 597.4 & $37.6-4207.9$ & 1119.9 & $95.6-3366.6$ & 573.9 & $35.7-4005.2$ & 928.8 & $29.7-4005.2$ \\
\hline $\mathrm{Ca}\left(\mathrm{mg} \cdot \mathrm{kg}^{-1}\right)$ & 8752.6 & $105.6-62834.9$ & 34826.6 & $93.7-110048.9$ & 4389.4 & 6.3-21066.6 & 21360.8 & $45.0-136017.0$ \\
\hline $\mathrm{CaCO}_{3}(\%)$ & 5.2 & $0.0-58.8$ & 30.1 & $0.0-85.0$ & 1.1 & $0.0-16.4$ & 14.6 & $0.0-93.9$ \\
\hline
\end{tabular}

Explanations: $\mathrm{C}$ - carbon, $\mathrm{N}$ - nitrogen, Org. mat. - organic matter content, $\mathrm{pH}$ - soil $\mathrm{pH}, \mathrm{P}$ - exchangeable phosphorus, $\mathrm{K}$ - exchangeable potassium, $\mathrm{Mg}-$ exchangeable magnesium, $\mathrm{Ca}$ - exchangeable calcium, $\mathrm{CaCO}_{3}$ - carbonates, $x$ - arithmetic mean, min and max - minimum and maximum values 


\begin{tabular}{ccccr}
\hline \multicolumn{5}{c}{ C. $\times$ subviridula } \\
\hline$x$ & $\min$ & $\max$ & \multicolumn{1}{c}{ SD } & \multicolumn{1}{c}{$V$} \\
\hline 34.7 & 18.9 & 56.9 & 11.96 & 34 \\
0.2 & 0.2 & 0.3 & 0.04 & 15 \\
14.3 & 7.5 & 21.6 & 4.04 & 28 \\
2 & 2 & 3 & 0.24 & 11 \\
5.1 & 2.2 & 13.5 & 3.04 & 60 \\
1.5 & 0.9 & 2.0 & 0.27 & 18 \\
0.2 & 0.1 & 0.2 & 0.02 & 10 \\
0.3 & 0.0 & 1.0 & 0.26 & 100 \\
3 & 2 & 5 & 0.76 & 24 \\
0.6 & 0.2 & 1.2 & 0.25 & 42 \\
2.7 & 0.8 & 9.5 & 2.82 & 103 \\
1.1 & 0.8 & 1.4 & 0.14 & 13 \\
0.7 & 0.6 & 0.9 & 0.05 & 8 \\
0.3 & 0.0 & 1.3 & 0.36 & 107 \\
11.0 & 4.9 & 16.8 & 3.03 & 27 \\
0.2 & 0.2 & 0.3 & 0.03 & 13 \\
0.8 & 0.2 & 4.2 & 0.92 & 120 \\
3 & 2 & 4 & 0.62 & 18 \\
0.9 & 0.7 & 1.1 & 0.13 & 15 \\
0.7 & 0.6 & 0.8 & 0.07 & 10 \\
5.7 & 2.4 & 11.7 & 2.55 & 44 \\
0.2 & 0.1 & 0.3 & 0.04 & 26 \\
3.6 & 3.3 & 3.9 & 0.14 & 4 \\
1.4 & 1.2 & 1.6 & 0.10 & 7 \\
39 & 35 & 41 & 1.98 & 5 \\
2.5 & 2.3 & 2.7 & 0.12 & 5 \\
1.4 & 1.2 & 1.5 & 0.10 & 7 \\
3.6 & 3.2 & 3.9 & 0.24 & 7 \\
1.6 & 1.4 & 1.9 & 0.10 & 6 \\
\hline & & & &
\end{tabular}

and 7). The measurements and analyses indicate that dimensions of utricle and its beak in hybrids are intermediate between parental taxa. The mean length of utricle and beak declines in the following order: $C . \times a l$ satica, $C . \times$ ruedtii, C. $\times$ subviridula, $C . \times$ schatzii, and C. demissa $\times$ C. viridula (Fig. 9A-B; Table 7), whereas the ratio of beak length to total utricle length declines from $C$. $\times$ alsatica to $C . \times$ schatzii in a slightly different order: $C . \times$ alsatica, $C . \times$ ruedtii, $C . \times$ subviridula,$C$. demissa $\times C$. viridula, and C. $\times$ schatzii (Fig. 9C; Table 7). Besides, utricles of hybrids are usually pale yellow or pale green soon after their formation and are flattened, usually empty.

\subsection{Relationships between taxa and soil parameters}

ANOVA revealed significant variation between habitats of taxa of the C. flava group in $\mathrm{pH}(p \leq 0.001)$, $\mathrm{CaCO}_{3}, \mathrm{C}$, and organic matter content $(p \leq 0.01)$, and $\mathrm{Ca}, \mathrm{N}$, and $\mathrm{K}(p \leq 0.05)$ (Tables 8-9). Most significant differences in soil parameters were found between sites of $C$. lepidocarpa and C. demissa (Table 9). In soil samples collected from sites of C. lepidocarpa, the $\mathrm{pH}$ values as well as concentrations of $\mathrm{CaCO}_{3}, \mathrm{Ca}, \mathrm{C}, \mathrm{N}$, and organic matter were higher than in samples from sites of $C$. demissa (Table 8). No significant differences in soil parameters were detected between sites of C. flava and C. demissa, and between those of C. flava and $C$. viridula. During field research, populations were often mixed, composed of C. demissa and C. flava, less often of C. flava and C. viridula. By contrast, specimens of $C$. lepidocarpa and $C$. demissa did not occur together, except for one site (no. 23 in Appendix 1), where C. demissa was accompanied by several specimens of C. lepidocarpa. The broadest ranges of values of soil parameters were recorded for $C$. viridula (Table 8). It coexists with $C$. lepidocarpa or $C$. demissa, and less often with C. flava (Appendix 1).

The ordination diagram shows the location of taxa in the ordination space, the distribution of samples from 80 sites, and vectors of soil parameters (Fig. 10).

Table 9. Results of one-way analysis of variance (ANOVA) and the post hoc Tukey HSD test for unequal N (Spjotvoll/Stoline test), showing significance of differences in soil conditions at sites of taxa of the Carex flava group

\begin{tabular}{|c|c|c|c|c|c|c|c|c|c|c|c|c|c|c|}
\hline \multirow{4}{*}{$\begin{array}{l}\text { Soil } \\
\text { parameters }\end{array}$} & \multirow{2}{*}{\multicolumn{2}{|c|}{$\frac{\text { ANOVA }}{\text { all taxa }}$}} & \multicolumn{12}{|c|}{ Post hoc Spjotvoll/Stoline test } \\
\hline & & & \multirow{2}{*}{\multicolumn{2}{|c|}{$\frac{\mathrm{F}-\mathrm{L}}{p}$}} & \multirow{2}{*}{\multicolumn{2}{|c|}{$\frac{\text { F-D }}{p}$}} & \multirow{2}{*}{\multicolumn{2}{|c|}{$\frac{\mathrm{F}-\mathrm{V}}{p}$}} & \multirow{2}{*}{\multicolumn{2}{|c|}{$\begin{array}{c}\text { L-D } \\
p\end{array}$}} & \multirow{2}{*}{\multicolumn{2}{|c|}{$\frac{\mathrm{L}-\mathrm{V}}{p}$}} & \multirow{2}{*}{\multicolumn{2}{|c|}{$\frac{\mathrm{D}-\mathrm{V}}{p}$}} \\
\hline & $F$ & $p$ & & & & & & & & & & & & \\
\hline & 5.760 & $* *$ & 0.085 & ns & 0.553 & ns & 0.603 & ns & 0.003 & $* *$ & 0.007 & $* *$ & 0.989 & ns \\
\hline$N(\%)$ & 3.873 & $*$ & 0.414 & ns & 0.584 & ns & 0.441 & ns & 0.038 & $*$ & 0.043 & $*$ & 0.999 & ns \\
\hline Org. mat. (\%) & 4.088 & $* *$ & 0.468 & ns & 0.541 & ns & 0.326 & ns & 0.040 & $*$ & 0.037 & $*$ & 0.999 & ns \\
\hline $\mathrm{pH}$ & 7.422 & $* * *$ & 0.031 & $*$ & 0.347 & ns & 0.449 & ns & 0.000 & $* * *$ & 0.341 & ns & 0.026 & * \\
\hline $\mathrm{P}\left(\mathrm{mg} \cdot \mathrm{kg}^{-1}\right)$ & 0.766 & ns & 0.761 & ns & 0.999 & ns & 0.767 & ns & 0.801 & ns & 0.994 & ns & 0.896 & $\mathrm{~ns}$ \\
\hline $\mathrm{K}\left(\mathrm{mg} \cdot \mathrm{kg}^{-1}\right)$ & 3.242 & $*$ & 0.794 & ns & 0.634 & ns & 0.294 & ns & 0.184 & ns & 0.977 & ns & 0.049 & $*$ \\
\hline $\operatorname{Mg}\left(\mathrm{mg} \cdot \mathrm{kg}^{-1}\right)$ & 1.176 & ns & 0.594 & ns & 0.999 & ns & 0.718 & ns & 0.561 & ns & 0.968 & ns & 0.789 & ns \\
\hline $\mathrm{Ca}\left(\mathrm{mg} \cdot \mathrm{kg}^{-1}\right)$ & 4.758 & $*$ & 0.063 & ns & 0.969 & ns & 0.371 & ns & 0,021 & $*$ & 0.564 & ns & 0.298 & ns \\
\hline $\mathrm{CaCO}_{3}(\%)$ & 5.486 & $* *$ & 0.020 & $*$ & 0.953 & ns & 0.447 & ns & 0.002 & $* *$ & 0.261 & ns & 0.049 & $*$ \\
\hline
\end{tabular}

Explanations: $\mathrm{D}-$ C. demissa, $\mathrm{F}-$ C. flava s.s., $\mathrm{L}-$ C. lepidocarpa, $\mathrm{P}-$ C. viridula var. pulchella, $\mathrm{V}-$ C. viridula var. viridula, $F-$ value of $F$ test, $\mathrm{ns}-\mathrm{non}-$ significant, $p$ - significance level, ${ }^{*} p 0.05,{ }^{* *} p \leq 0.01,{ }^{* *} p \leq 0.001, \mathrm{C}-$ carbon, $\mathrm{N}-$ nitrogen, Org. mat. - organic matter content, $\mathrm{pH}-\mathrm{soil} \mathrm{pH}, \mathrm{P}-\mathrm{ex}-$ changeable phosphorus, $\mathrm{K}$ - exchangeable potassium, $\mathrm{Mg}$ - exchangeable magnesium, $\mathrm{Ca}$ - exchangeable calcium, $\mathrm{CaCO}_{3}-$ carbonates 


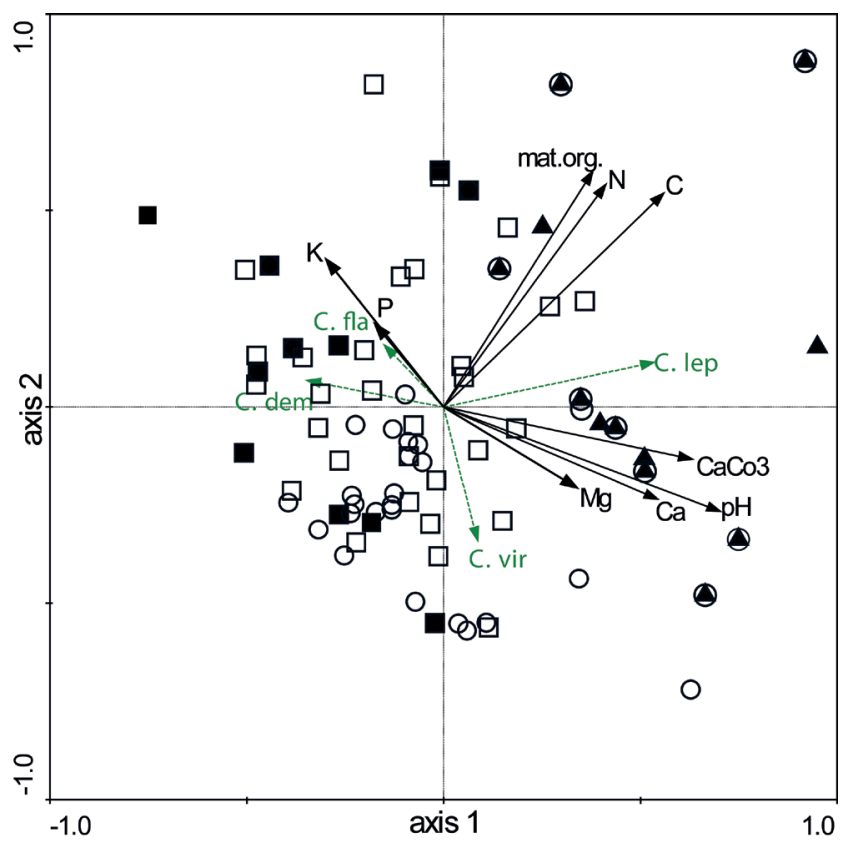

Fig. 10. Ordination diagram (redundancy analysis, RDA) showing correlations between taxa of the Carex flava group and soil parameters

Explanations: C. dem-Carex demissa, C. lep.-Carex lepidocarpa, C. vir. - Carex viridula, $\square$ - samples from sites of C. flava, $\mathrm{O}$ - samples from sites of $C$. viridula var. viridula, $\mathbf{\square}$ - samples from sites of $C$. demissa, $\Delta-$ samples from sites of C. lepidocarpa. Loadings for the first axis: $\mathrm{pH}=0.43$, $\mathrm{CaCO}_{3}=0.38, \mathrm{C}=0.34, \mathrm{Ca}=0.33, \mathrm{~N}=0.25$, mat.org. (organic matter) $=$ $0.23, \mathrm{Mg}=0.20, \mathrm{~K}=-0.18, \mathrm{P}=-0.11$. Loadings for the second axis: mat. org. (organic matter) $=0.20, \mathrm{~N}=0.19, \mathrm{C}=0.18, \mathrm{~K}=0.13, \mathrm{pH}=-0.09, \mathrm{Ca}$ $=-0.08, \mathrm{P}=0.07, \mathrm{Mg}=-0.07, \mathrm{CaCo}_{3}=0.04$

Along the first ordination axis, correlations between soil parameters and sample location were the highest for $\mathrm{pH}$ (Fig. 10). The first axis was less strongly connected with $\mathrm{CaCO}_{3}, \mathrm{C}$, and $\mathrm{Ca}(r=0.3840, r=0.3399$, and $r$ $=0.3307$, respectively). Along the second ordination axis, only relatively low correlations were recorded, for organic matter content, $\mathrm{N}$, and $\mathrm{C}(r=0.2013, r=$ 0.1899 , and $r=0.1826$, respectively) (Fig. 10). The test of significance of ordination axes shows a significant relationship between the analysed samples and gradients of canonical axes of RDA (first axis: $F=11.817, p=$ 0.002; all axes: $F=2.155, p=0.006$ ). The distribution of samples from sites of $C$. lepidocarpa along the first axis indicates their directly proportional relationship with $\mathrm{pH}$ and concentrations of $\mathrm{CaCO}_{3}, \mathrm{Ca}$, and $\mathrm{C}$ in the soil (in contrast to samples from populations of C. flava and especially of $C$. demissa). The distribution of taxa in the diagrams corresponds to observations during field research: mixed populations were usually composed of C. Alava with C. demissa, or C. lepidocarpa with $C$. viridula, less often of C. Alava with C. lepidocarpa, or $C$. flava with C. viridula, and only rarely of C. lepidocarpa with $C$. demissa (Appendix 1; Fig. 10).

The Monte Carlo permutation test $(p \leq 0.05)$ shows that $\mathrm{pH}$ and organic carbon content are significant in
Table 10. Results of Monte Carlo permutation test (* $p \leq 0.05)$ for taxa of the Carex flava group

\begin{tabular}{lccc}
\hline Soil parameters & Lambda A & $p$ & $F$ \\
\hline $\mathrm{pH}^{*}$ & 0.07 & 0.004 & 6.76 \\
$\mathrm{C}^{*}(\%)$ & 0.04 & 0.010 & 3.99 \\
$\mathrm{~N}(\%)$ & 0.02 & 0.056 & 2.64 \\
$\mathrm{~K}(\mathrm{mg} \bullet \mathrm{kg}-1)$ & 0.01 & 0.236 & 1.39 \\
$\mathrm{P}(\mathrm{mg} \cdot \mathrm{kg}-1)$ & 0.01 & 0.388 & 0.93 \\
Org. mat. $(\%)$ & 0.02 & 0.216 & 1.55 \\
$\mathrm{Mg}(\mathrm{mg} \bullet \mathrm{kg}-1)$ & 0.00 & 0.790 & 0.56 \\
$\mathrm{CaCO}(\%)$ & 0.01 & 0.706 & 0.56 \\
$\mathrm{Ca}(\mathrm{mg} \cdot \mathrm{kg}-1)$ & 0.00 & 0.446 & 0.91 \\
\hline
\end{tabular}

Explanations: $\mathrm{C}$ - carbon, $\mathrm{N}$ - nitrogen, Org. mat. - organic matter content, $\mathrm{pH}$ - soil $\mathrm{pH}, \mathrm{P}$ - exchangeable phosphorus, $\mathrm{K}$ - exchangeable potassium, $\mathrm{Mg}$ - exchangeable magnesium, $\mathrm{Ca}$ - exchangeable calcium, $\mathrm{CaCO}_{3}$ - carbonates

the relationships between taxa and soil parameters. The other soil parameters are statistically not significant in this model but $\mathrm{pH}$ affects also some other parameters, e.g. $\mathrm{Ca}$ and $\mathrm{CaCO}_{3}$, which are significantly correlated with each other and with soil $\mathrm{pH}$. Values of $\mathrm{pH}$ and organic carbon content significantly explain $11 \%$ of the total variation in distribution of taxa from the analysed data set: $7 \%$ and $4 \%$, respectively (Table 10 ).

\subsection{Key to identification of taxa within the section Ceratocystis}

The crucial morphological characters concern the utricle and its beak: utricle length, beak length, ratio of beak length to total utricle length, beak curvature, and presence of bristles. Sedges should be fully developed, as only mature utricles, from central parts of spikes, should be used for identification (especially when estimating the ratio of fruit size to utricle size). In the case of a species aggregate, like C. flava agg., many morphological characters should be used for identification of individual taxa. Whenever possible, several specimens from the same population should be compared, measured, and mean values of metric characters should be used (Tables 2 and 7).

The key takes into account all taxa of the section Ceratocystis (C. flava agg., C. hostiana, and hybrids) recorded in Poland.

1a All utricles with mature fruits (on fully mature plants)

1b Utricles empty or only $10 \%$ to $20(30) \%$ utricles with fully developed fruits.

2a Loosely tufted plants, with well-developed short rhizomes; female spikes distant, narrowly ovoid to terete, 
lowest spike on peduncle of 10-50 $\mathrm{mm}$ in length; lowest female spike bract shorter than inflorescence, with sheath of 10-40 mm in length; glumes dark brown, with broad hyaline margin; utricle beak with white membrane at apex

Carex hostiana

2b Tufted plants; female spikes close together, ovoid to spherical, lowest spike more or less distant from others, usually on peduncle of up to $35 \mathrm{~mm}$ in length; lowest female spike bract longer, even or slightly shorter than inflorescence; bracts with short sheaths, uppermost bracts usually sheathless; glumes light brown to rusty brown, with usually narrow hyaline margin; utricle beak without white membrane at apex....3 (Carex flava agg.)

3a Utricles with curved beaks.

3b Utricles with straight beaks.

4a Utricles 4-6(6.5) mm long, gradually narrowed into bifid beak, its outer surface usually scabrous $(>5$ bristles on each tooth); beak $\geq 1.8 \mathrm{~mm}$ long (accounting for $1 / 2$ of total utricle length); male spike sessile or rarely on peduncle of up to $10(15) \mathrm{mm}$ in length; lowest female spike bract 2-5 times as long as inflorescence, usually $2-4(5) \mathrm{mm}$ wide; cauline leaves usually as long as culm, rarely longer or slightly shorter; ligule well-defined, usually $>3 \mathrm{~mm}$ long.

Carex flava s.s. 4b Utricles 3.5-4.5(5) $\mathrm{mm}$ long, abruptly narrowed into beak, smooth or with several bristles $(<5$ on each tooth) beak $\leq 1.8 \mathrm{~mm}$ long (accounting for $1 / 3$ of total utricle length); male spike on peduncle of 2-60 $\mathrm{mm}$ in length; lowest female spike bract usually as long as or shorter than inflorescence, rarely up to 1.5 times as long as inflorescence, 1-2(3) mm wide; leaves usually up to $1 / 2$ as long as culm, rarely as long as or slightly longer than culm; ligule $<2.5 \mathrm{~mm}$..

Carex lepidocarpa $(=$ C. lepidocarpa subsp. lepidocarpa $)$

5a Utricles 3-4(4.5) mm long; beak 0.9-1.8 mm long (accounting for $35-45 \%$ of total utricle length); female spikes 2-4(5), uppermost ones close together, lowest spike distant and often located below half the length of culm; male spike usually on peduncle of up to $21 \mathrm{~mm}$ in length; culm often slightly bent; leaves usually shorter than culm, rarely as long as or longer than culm.

\section{Carex demissa}

5b Utricles $\leq 4 \mathrm{~mm}$ long; beak $\leq 1.5 \mathrm{~mm}$ long (accounting for $23-36 \%$ of total utricle length); female spikes 2-6(7), typically clustered below male spike, rarely distant; male spike sessile or rarely on peduncle of variable length; culm erect; leaves usually longer or as long as culm.

6 (Carex viridula)

6a Utricles 2-4 mm long; beak 0.6-1.3 mm long; female spikes (2)3-6(7), 4-8 mm wide; usually fruit filling $<3 / 4$ of utricle body. Carex viridula var. viridula 6b Utricles 1.8-2.6 mm long; beak $<1 \mathrm{~mm}$ long; female spikes usually 2-3, 4-6 mm wide; fruit completely filling utricle body.

Carex viridula var. pulchella

7a Utricle beak with white membrane at apex; glumes with wide white membranous margin

8 (C. hostiana $\times$ C. flava agg.)

7b Utricle beak without white membrane at apex; glumes with narrow white membranous margin

.9 (hybrids within $C$. flava agg.)

8a Female spikes $8-20 \mathrm{~mm}$ long and 5-7.5 $\mathrm{mm}$ wide, usually distant from one another; distance between first and second female spike $10-110 \mathrm{~mm}$; male spikes on peduncles of up to $40 \mathrm{~mm}$ in length; utricle $3-4 \mathrm{~mm}$ long; beak 1-1.6 mm long (accounting for $35-44 \%$ of total utricle length).

Carex $\times$ fulva $[$ C. demissa $\times$ C. hostiana $]$ 8b Female spikes 7-16 mm long and 6-9 mm wide, usually close together but sometimes distant, distance between first and second female spike $2-40 \mathrm{~mm}$; male spikes on peduncles of up to $20 \mathrm{~mm}$ in length; utricle 3.5-4.5 mm long; beak 1.2-1.5 mm long (accounting for $30-38 \%$ of total utricle length).

Carex $\times$ leutzii $[$ C. hostiana $\times$ C. lepidocarpa $]$

9a Utricles usually $4-5 \mathrm{~mm}$ long; beak $\geq 1.5 \mathrm{~mm}$......10

9b Utricles $\leq 4 \mathrm{~mm}$ long; beak $\leq 1.6 \mathrm{~mm}$....................11

10a Beak accounting for nearly $1 / 2$ of total utricle length (40-49\%); lowest female spike bract usually $3 \mathrm{~mm}$ wide; bract of second female spike usually about $2 \mathrm{~mm}$ wide Carex $\times$ alsatica $[$ C. demissa $\times$ C. flava $]$ $10 \mathrm{~b}$ Beak accounting for about $1 / 3$ of total utricle length (37-45\%); lowest female spike bract usually about $2 \mathrm{~mm}$ wide; bract of second female spike usually about $1 \mathrm{~mm}$ wide............Carex $\times$ ruedtii $[$ C. flava $\times$ C. lepidocarpa $]$

11a Female spikes 1-3(4); male spike usually on peduncle of up to $40 \mathrm{~mm}$ in length; lowest female spike bract usually 1-2(3) mm wide; bract of second female spike usually up to $1 \mathrm{~mm}$ wide; uppermost cauline leaves usually much shorter than culm, rarely as long or longer than culm......Carex $\times$ schatzii $[$ C. lepidocarpa $\times$ C. viridula $]$ 11b Female spikes 2-4(5), male spike sessile or rarely on peduncle of up to $15 \mathrm{~mm}$ in length; lowest female spike bract usually 2-3 mm wide; bract of second female spike usually $2 \mathrm{~mm}$ wide .12

12a Beak 1.2-1.6 mm long; female spikes 6-9 mm wide; male spike usually sessile or on peduncle of up to $10 \mathrm{~mm}$ long..............Carex $\times$ subviridula $[$ C.flava $\times$ C. viridula $]$ 12b Beak $\leq 1.2 \mathrm{~mm}$ long; female spikes $5-7 \mathrm{~mm}$ wide; male spike on peduncle of up to $15 \mathrm{~mm}$ long..

Carex demissa $\times$ Carex viridula 


\subsection{Description of taxa and hybrids}

Carex flava L. 1753, Sp. P1.: 975. Type: LINN Savage Cat. No. 1100.40 (Lectotype: LINN).

Synonyms: - C. flava L. var. densa Gaud. 1830, Fl. Helv. 6: 97; - C. flava L. var. rectirostra Gaud. 1830, Fl. Helv. 6: 97; - C. flava L. var. patula Klett et Richter 1830, Fl. Leibzig: 758; - C. flava L. var. rectirostris Poterm. 1844, Flora 27: 338; - C. flava L. var. deficiens Poterm. 1844, Flora 27: 339; -C. flava L. var. pygmaea Anderss. 1849, Pl. Scand.: 25; - C. flavofulva Beurling 1853, Bot. Not.: 37 ; - C. flava L. var. macrorrhyncha Čelak. 1867, Prodr. Fl. Böhmen. 1: 71; - C. flava L. var. alpina Kneucker 1899, Allg. Bot. Z. Syst. 5: 8; C. flava L. f. umbrosa Kneucker 1899, Allg. Bot. Z. Syst. 5: 8; - C. flava L. f. uetliaca (Suter) Aschers. et Graebner 1903, Syn. Mitteleur. Fl. 2(2): 200; - C. flava L. var. brevirostris Aschers. et Graebner 1903, Syn. Mitteleur. Fl. 2(2): 201; - C. flava subsp. euflava Aschers. et Graebner 1903, Syn. Mitteleur. Fl. 2(2): 199; $-C$. flava L. var. gaspensis Fernald 1906, Rhodora 8: 200; C. lepidocarpa Tausch var. laxior Kük. 1909 in Engler Pflanzenreich 38(20): 673; C. oederi Retz. f. graminea Kük. 1909 in Engler Pflanzenreich 38(20): 674; $-C$. flavella V. Kreč. in Majevski Fl. Centr. Rus.s, 6: 184, 1933; id. in Komarov Fl. USRR, 3: 388, 617, 1935; $C$. laxior (Kük.) Mackenze 1935, Fl. North. Amer., 18,5: 306; - C. flava L. var. laxior (Kük.) Gleason 1952, Phytologia 4: 22; - C. nevadensis Boiss. et Reuter subsp. flavella (V. Kreč.) Patzke et Podlech 1959 in Janchen Cat. Fl. Austr., 1(4): 774.

Culms 12-70 $\mathrm{cm}$ high, 0.7-1.8 mm wide (width measured above uppermost cauline leaf). Leaves yellow-green, usually as long as culm, rarely longer or slightly shorter; uppermost cauline leaf $8-30 \mathrm{~cm}$ long and 2-5 $\mathrm{mm}$ wide, with well-developed sheath of $10-120 \mathrm{~mm}$ in length and ligule usually $>3 \mathrm{~mm}$ long; basal leaves 6-35 cm long and 3-6 $\mathrm{mm}$ wide. Inflorescence 1.5-6(20) $\mathrm{cm}$ long. Male spike single, terminal, 8-22 mm long, 1-2 mm wide, usually sessile or on peduncle of 10(15) mm in length; male glumes usually obtuse, obovate 2.9-4.4 mm long, 1.1-1.9 mm wide, usually brown or rusty brown, with pale midrib region and narrow hyaline margin. Female spikes 1-3(5), usually 2 uppermost close together, remaining spikes distant from them, ellipsoid or spherical, 9-22 mm long, 7-11 mm wide, all sessile or lowest spike on peduncle of 5 (up to 32) $\mathrm{mm}$ long. Lowest female spike bract 2-5 times as long as inflorescence, 3.2-26.5 cm long, 2-4(5) $\mathrm{mm}$ wide, bract sheath 1-44 mm long; bract of second female spike 1.3-10.9 mm long, 1-2(3) mm wide, usually sheathless. Utricles 4-6(6.5) $\mathrm{mm}$ long, $1.0-1.9 \mathrm{~mm}$ wide, gradually tapering into curved, bifid beak, its outer surface usually scabrous ( $>5$ bristles on each tooth); beak 1.8-2.8 mm long, usually accounting for $1 / 2$ of total utricle length. Fruit only partly filling utricle body $(1 / 3$ to $1 / 2)$. Female glumes variable, from obtuse to acute, or rarely acuminate, 2.3-4.2 mm long, 1.2-2.1 mm wide, light to dark brown, with green midrib region and narrow hyaline margin.

Carex lepidocarpa Tausch 1834, Flora (Regensburg) 17: 179. Type: Czechoslovakia, Praha, (no collector), no. 1636 (lectotype: PRC, isolectotype: PRC, selected by Crins 1985).

Synonyms: - C. flava var. elatior Schltdl. 1823, Fl. Berol. 1: 477; - C. oederi Retz. var. elatior Gaudin 1830, F1. Helv. 6: 96; - C. flava L. var. polystachya Gaudin 1830, Fl. Helv. 6: 97; - C. flava L. var. lepidocarpa (Tausch) Godr. 1844, Fl. Lorraine, 3: 118; - C. flava L. var. brachyrrhyncha Čelak. 1867, Prodr. Fl. Böhmen. 1: 71;-C. lepidocarpa Tausch var. pseudolepidocarpa Kneucker 1899, Allg. Bot. Z. Syst. 5: 9; - C. lepidocarpa Tausch f. rectirostris Kneucker 1899, Allg. Bot. Z. Syst. 5: 9; - C. lepidocarpa Tausch f. laeviculmis Kneucker 1899, Allg. Bot. Z. Syst. 5: 10; - C. lepidocarpa Tausch f. major Kneucker 1899, Allg. Bot. Z. Syst. 5: 10;-C. lepidocarpa Tausch f. intermedia (Coss. et Germ.) Aschers. et Graebner 1903, Syn. Mitteleur. Fl. 2(2): 200;-C. lepidocarpa Tausch var. nelmesiana Raymond 1952, Bull. Soc. Bot. Fr. 99: 194; - C. viridula Michaux subsp. brachyrrhyncha (Čelak.) B. Schmid var. lepidocarpa (Tausch) B. Schmid 1983, Watsonia 14: 317; C. viridula Michaux subsp. brachyrrhyncha (Čelak.) B. Schmid var. elatior (Schltdl.) Crins 1989, Can. J. Bot. 67: 1058.

Culms 20-85 cm high, 0.7-1.3 mm wide (above uppermost cauline leaf). Leaves yellow-green, usually much shorter than culm; uppermost cauline leaf 5.5$22.5 \mathrm{~cm}$ long and 2-4 mm wide, its sheath $9.5-100 \mathrm{~mm}$ long, and ligule usually $<2.5 \mathrm{~mm}$ long; basal leaves 6.5-30.5 mm long, 2.5-6 mm wide. Inflorescence 2.5$10(23) \mathrm{cm}$ long. Male spike single, terminal, $10-31 \mathrm{~mm}$ long, 1-2 mm wide, on peduncle of 2-60 $\mathrm{mm}$ in length; male glumes 2.9-4.2 mm long, 1.3-2.1 mm wide, light to dark brown, with pale midrib region and narrow to broad hyaline margin. Female spikes 1-3(4), usually distant, ellipsoid, 8-22 mm long, 7-10 mm wide, all sessile or lowest spike rarely on peduncle of 4 (up to 33) mm long. Lowest female spike bract usually as long or shorter than inflorescence, rarely up to 1.5 as long as inflorescence, 0.6-17.7 cm long, 1-2(3) $\mathrm{mm}$ wide, bract sheath 1-42 mm long; bract of second female spike 0.4-7.5 mm long, usually $<1 \mathrm{~mm}$ wide, sheathless. Utricles 3.5-4.5(5) $\mathrm{mm}$ long, 1.1-2.0 mm wide, abruptly contracted into usually curved, bifid beak, its outer surface smooth or scabrous $(<5$ bristles on each tooth); beak 1.1-1.8 mm long, usually accounting for 
$1 / 3$ of total utricle length. Fruit filling about $1 / 2$ of utricle body. Female glumes variable, from obtuse to acute, 2.1-3.3 mm long, 1.3-2.1 mm wide, light to dark brown, with green midrib region and hyaline margin.

Carex demissa Hornem. 1808, Fl. Dan. 8(23): 4. Type: Denmark, in rupibus Telemarkiae, Vahl (Holotype: C). Synonyms: - C. tumidicarpa Andersson 1849, Bot. Not.: 16 ; - C. oederi Retz. subsp. oedocarpa Andersson 1849, Pl. Scand: 25; - C. flava L. f. demissa (Hornem.) Kük. 1909 in Engler Pflanzenreich, 38(20): $672 ;-C$. oederi Retz. f. oedocarpa (Andersson) Kük. 1909 in Engler Pflanzenreich, 38(20): 674; - C. viridula Michaux subsp. oedocarpa (Andersson) B. Schmid 1983, Watsonia 14: 316;-C. flava L. subsp. oedocarpa (Andersson) P. D. Sell 1996 in Sell \& Murrell, Fl. Great Britain Ireland 5: 110.

Culms 6-60 $\mathrm{cm}$ high, 0.6-1.4 mm wide (above uppermost cauline leaf), usually decumbent. Leaves usually shorter than culm, less often as long or longer than culm; uppermost cauline leaf 3-18 cm long, 2-4 mm wide, its sheath 10-60 $\mathrm{mm}$ long and ligule up to $2.5 \mathrm{~mm}$ long; basal leaves $4.5-30 \mathrm{~cm}$ long, 2.5-5.5 mm wide. Inflorescence 2-12(34) cm long. Male spike single, terminal, 8-22 mm long, 1-2 mm wide, usually on peduncle of up to $21 \mathrm{~mm}$ in length; male glumes 3.1-5.2 $\mathrm{mm}$ long, 1.2-2.0 mm wide, usually dark brown, with pale midrib region and narrow hyaline margin. Female spikes 2-4(5), usually 2-3 uppermost ones close together, lowest distant from them, often located below half the length of culm; ellipsoid, 6-16 mm long, 4-9 mm wide, sessile or lowest spike on peduncle of 4 (up to 21) $\mathrm{mm}$ in length. Lowest female spike bract usually as long or, less often, shorter or longer than inflorescence, 2.4$18.8 \mathrm{~cm}$ long, 2-3(4) $\mathrm{mm}$ wide, bract sheath 1-44 mm long; bract of second female spike $0.8-11.4 \mathrm{~mm}$ long, usually up to $1-2 \mathrm{~mm}$ wide, sheathless. Utricles 3-4(4.5) mm long, 1.1-1.9 mm wide, gradually tapering into straight or rarely slightly curved bifid beak, smooth or scabrous (with sparse bristles); beak 0.9-1.8 mm long (accounting for $35-45 \%$ of total utricle length). Fruit only partly filling utricle body $(1 / 2$ to $2 / 3)$. Female glumes $2.0-3.5 \mathrm{~mm}$ long, 1.1-2.0 $\mathrm{mm}$ wide, variable, from obtuse to acute, light to dark brown, with green midrib region and narrow hyaline margin.

Carex viridula Michx. 1803, Fl. Bor.-Amer. 2: 170. Type: Canada, entre Montreal et Trois Rivieres, Michaux (Holotype: P).

Synonyms: - C. oederi Ehrhart 1791, Beitr. Naturk. 6: 83; - C. serotina Mérat 1821, Nouv. Fl. Env. Paris, ed. 2, 2: 54; - C. subglobosa Mielichhofer 1839, Flora (Regensburg) 22: 257; - C. oederi Retz. var. brevirostris Aschers. et Graebner 1903, Syn. Mitteleur. Fl. 2(2):
201; - C. oederi Retz. f. alpestris Aschers. et Graebner 1903, Syn. Mitteleur. Fl. 2(2): 201; - C. oederi Retz. f. thalassica Aschers. et Graebner 1903, Syn. Mitteleur. F1. 2(2): 202; - C. flava var. viridula (Michx.) Aschers. et Graebner. 1903, Syn. Mitteleur. Fl. 2(2): 201; C. oederi Retz. f. tenuis Zapałowicz 1906, Consp. Fl. Gallic. Crit. 1: 114; - C. oederi var. pumila (Cosson and Germain) Fernald 1906, Rhodora 8: 201; - C. oederi Retz. var. viridula (Michaux) Kük. 1909 in Engler Pflanzenreich, 38(20): 674; - C. oederi Retz. f. argillacea (Townson) Kük. 1909 in Engler Pflanzenreich, 38(20): $674 ;-$ C. oederi Retz. f. recterostrata (L. H. Bailey) Kük. 1909 in Engler Pflanzenreich, 38(20): 674;-C. kotilainii Palmgr. 1944, Memoranda Soc. Fauna Fl. Fenn. 19: 89; - C. oederi Retz. subsp. fennica Palmgr. 1958, Commentat. Biol. 20(3): 8; - C. serotina Mérat subsp. fennica (Palmgr.) Á. Löve \& D. Löve 1961, Bot. Not. 114: 5; - C. serotina Mérat subsp. philocrena (V. I. Kreč.) Kukkonen 1984, Ann. Bot. Fenn. 21: 387; - C. viridula Michaux subsp. serotina (Mérat) Malyschev 1990 in Fl. Sibir., 3: 130; - C. viridula Michaux subsp. viridula var. viridula, B. Schmid 1983, Watsonia 14: 313;-C. flava L. subsp. serotina (Mérat) P. D. Sell in 1996 in Sell \& Murrell, Fl. Great Britain Ireland 5: 110.

Culms 3-40(50) $\mathrm{cm}$ high, 0.5-1.1 mm wide (above uppermost cauline leaf), usually erect. Leaves usually shorter than culm; uppermost cauline leaf $3.1-23.1 \mathrm{~cm}$ long, 1-3 mm wide, its sheath 5.5-30 $\mathrm{mm}$ long and ligule usually $<1 \mathrm{~mm}$ long; basal leaves $3.5-35 \mathrm{~cm}$ long, 2-4 mm wide. Inflorescence 1.2-6(16.1) $\mathrm{cm}$ long. Male spike single, terminal, 4-20 mm long, 1-2 mm wide, usually sessile, rarely on peduncle of about $1-3 \mathrm{~mm}$ in length (exceptionally $20 \mathrm{~mm}$ ); male glumes $2.4-4.2 \mathrm{~mm}$ long, 1.2-2.1 mm wide, variable, lanceolate to ovate, obtuse to acute, usually dark brown with pale midrib region and narrow hyaline margin. Female spikes (2)36(7), usually close together, sometimes lowest distant from them, may be located below half the length of culm, spherical or ellipsoid, 4-14 mm long, 4-8 mm wide, sessile or lowest spike on peduncle of 2 (up to 32) $\mathrm{mm}$ long. Lowest female spike bract usually longer than inflorescence, $2.8-21.7 \mathrm{~cm}$ long, 1-3 mm wide, bract sheath 0-50(92) mm long; bract of second female spike $9.8 \mathrm{~mm}$ long, up to $1-2 \mathrm{~mm}$ wide, sheathless. Utricles 2.1-4.1 mm long, 0.9-1.5 mm wide, gradually tapering into straight, smooth, bifid beak; beak 0.6$1.3 \mathrm{~mm}$ long (accounting for $23-36 \%$ of total utricle length). Fruit only partly filling utricle body ( $2 / 3$ to $3 / 4)$. Female glumes $1.5-3.0 \mathrm{~mm}$ long, $1.0-1.7 \mathrm{~mm}$ wide, light to dark brown, with green midrib region and narrow hyaline margin.

Carex viridula Michx. var. pulchella (Lönnr.) B. Schmid 1983, Watsonia 14: 316 
Type: Sweden, Gottland, Norrlanda, Lönnroth (Lectotype: UPS)

Synonyms: - C. oederi Retz. f. pygmaea Andersson 1849, P1. Scand.: 25; - C. oederi Retz. subsp. pulchella Lönnr. 1854, Obs. Crit. Pl. Suec.: 24; - C. pulchella (Lönnr.) Lindman 1918, Svensk Fanerogamfl.: 143; - C. serotina Mérat subsp. pulchella (Lönnr.) Ooststr. 1949, in H.Heukels and W. H. Wachter, Bekn. Schoolfl. Nederl. ed. 7: 319; -C. scandinavica E. W. Davies 1953, Watsonia 3: 66; - C. viridula Michaux subsp. viridula var. pulchella (Lönnr.) B. Schmid 1983, Watsonia 14: 316; - C. viridula Michaux subsp. pulchella (Lönnr.) Malyschev 1990 in Fl. Sibir. 3: 130;-C. flava L. subsp. pulchella (Lönnr.) P. D. Sell in 1996 in Sell \& Murrell, Fl. Great Britain Ireland 5: 110; - C. oederi Retz. var. pulchella (Lönnr.) Hedrén \& Lassen 2003, Nord. J. Bot. 22: 262.

Culms 2.8-11.3 cm high, 0.6-0.9 mm wide (above uppermost cauline leaf), usually erect. Leaves usually as long as culm; uppermost cauline leaf 2.5-6 cm long, and 1-2 mm wide, with well-developed sheath of 1.5$2 \mathrm{~mm}$ in length, and poorly developed ligule, usually $<1 \mathrm{~mm}$ long; basal leaves $3.5-11.5 \mathrm{~cm}$ long, $1.5-3 \mathrm{~mm}$ wide. Inflorescence $0.7-3 \mathrm{~cm}$ long. Male spike single, terminal, 5-14 mm long, 1-2 mm wide, sessile or on peduncle of up to $3 \mathrm{~mm}$ in length; male glumes 2.8 $3.3 \mathrm{~mm}$ long, 1.3-1.6 mm wide, dark brown with pale midrib region and narrow hyaline margin. Female spikes 2-3, usually close together, spherical or ellipsoid, 5-8 mm long, 4-6 mm wide, sessile or lowest spike on peduncle of up to $3 \mathrm{~mm}$ in length. Lowest female spike bract usually longer than inflorescence, $1.8-4.5 \mathrm{~cm}$ long, 1-2 mm wide, bract sheath 1-3 mm long; bract of second female spike 0.1-1.9 mm long, usually $<1 \mathrm{~mm}$ wide, sheathless. Utricles 1.8-2.6 mm long, 0.8-1.1 mm wide, gradually tapering into straight, smooth, bifid beak; beak 0.6-0.8 mm long (accounting for $27-32 \%$ of total utricle length). Fruit completely filling utricle body. Female glumes 1.4-2.2 mm long, 1.0-1.4 mm wide, usually dark brown with green midrib region and narrow hyaline margin.

Carex $\times$ fulva Gooden. 1794, Trans. Linn. Soc. London 2: 177

C. demissa Hornem. $\times$ C. hostiana DC.

Synonyms: $-C$. $\times$ flavescens Host 1809, Icon Descr. Gram. Austriac. 4: 53; - C. biformis F. W. Schultz var. sterilis 1841, Flora 24: 55; - C. ×appeliana Zahn 1890, Oesterr. Bot. Z. 40: 364; C. ×brueggeri K. Richter 1890, Pl. Eur. 1: 170.

Culms 18.0-54.5 cm high, 0.8-1.1 mm wide (above uppermost cauline leaf). Leaves usually shorter than culm; uppermost cauline leaf $5.5-14.2 \mathrm{~cm}$ long and $2-3 \mathrm{~mm}$ wide, with sheath of $10-50 \mathrm{~mm}$ in length. Inflorescence 4.1-17.1 cm long. Male spike single, terminal, 12$24 \mathrm{~mm}$ long, 1-2 mm wide, sessile or on peduncle of up to $40 \mathrm{~mm}$ in length. Male glumes with broad hyaline margin. Female spikes 1-3, usually distant, distance between first and second female spike 10-110 $\mathrm{mm}$ (on average $40 \mathrm{~mm}$ ); female spikes $8-20 \mathrm{~mm}$ long, $5-7.5 \mathrm{~mm}$ wide, sessile or lowest spike on peduncle of up to $30 \mathrm{~mm}$ in length. Lowest female spike bract usually shorter than inflorescence, 3.7-12.9 cm long, 2-3 mm wide, bract sheath $2.4-28 \mathrm{~mm}$ long. Utricles $3-4 \mathrm{~mm}$ long, 1.1-1.8 mm wide; beak 1-1.6 mm long (accounting for $35-44 \%$ of total utricle length) with white membrane at apex. Female glumes with variable hyaline margin.

Carex $\times$ leutzii Kneuck. 1891, in Seubert, Excurs. Fl. Baden, ed.5: 68

C. hostiana DC. $\times$ C. lepidocarpa Tausch

Synonyms: - C. $\times$ xanthocarpa Degland var. leutzii (Kneucker) Rouy 1912, in Rouy \& Foucaud, Fl. France 13: 475; - C. ×pseudofulva Fernald 1933. Rhodora 35: 231

Culms 21.5-52.7 $\mathrm{cm}$ high, 0.8-1.3 mm wide (above uppermost cauline leaf). Leaves usually shorter or as long as culm; uppermost cauline leaf 4.9-10.9 cm long and 2-3 mm wide, with sheath of 10-48 mm long. Inflorescence 3.6-10.5 cm long. Male spike single, terminal, 12-24 mm long, 1-2 mm wide, sessile or on peduncle of up to $20 \mathrm{~mm}$ in length. Male glumes with broad hyaline margin. Female spikes 1-3, usually close together but sometimes distant, distance between first and second female spike 2-40 $\mathrm{mm}$ (on average $16 \mathrm{~mm}$ ); female spikes 7-16 mm long, 6-9 mm wide, sessile or lowest spike on peduncle of up to $11 \mathrm{~mm}$ in length. Lowest female spike bract usually shorter than inflorescence, 3.5-7.5 cm long, 1-2.5(3) mm wide, bract sheath 2.1$24 \mathrm{~mm}$ long. Utricles 3.5-4.5 mm long, 1.1-1.8 mm wide; beak 1.2-1.5 mm long (accounting for $30-38 \%$ of total utricle length) with white membrane at apex. Female glumes with variable hyaline margin.

Carex $\times$ alsatica Zahn 1890, Oesterr. Bot. Z. 40: 363 C. demissa Hornem. $\times$ C. flava $\mathrm{L}$.

Culms 15.2-37.5 cm high, 0.8-1.4 mm wide (above uppermost cauline leaf). Leaves usually slightly shorter or as long as culm; uppermost cauline leaf 6-20 cm long and 2-4 $\mathrm{mm}$ wide, with sheath of $10-60 \mathrm{~mm}$ in length; basal leaves 7.5-32.5 cm long, 3-5 mm wide. Inflorescence 2.5-21.6 cm long. Male spike single, terminal, 10-22 mm long, 1-2 mm wide, sessile or on peduncle of up to $13 \mathrm{~mm}$ long; male glumes 3.1-4.1 mm long, 1.3$1.9 \mathrm{~mm}$ wide, brown with pale midrib region and narrow hyaline margin. Female spikes 2-4, usually lowest 
distant from others, ellipsoid or spherical, 7-16 mm long, 6-14 mm wide, sessile or lowest spike on peduncle of up to $9 \mathrm{~mm}$ long. Lowest female spike bract usually longer than inflorescence, $3.5-19.9 \mathrm{~cm}$ long, 2-3 mm wide, bract sheath $2-28 \mathrm{~mm}$ long; bract of second female spike 2.2-9.6 mm long, 1-2 mm wide, usually sheathless. Utricles 3.6-5.3 mm long, 1.1-1.8 mm wide, gradually tapering into slightly curved or straight, bifid beak, smooth or scabrous (with sparse bristles); beak 1.5-2.4 mm long (accounting for 40-49\% of total utricle length). Female glumes $2.4-3.5 \mathrm{~mm}$ long, $1.3-1.8 \mathrm{~mm}$ wide, dark brown with green midrib region and narrow hyaline margin, obtuse or acute at apex, variable.

Carex $\times$ ruedtii Kneuck. 1891, in Seubert, Excurs. Fl. Baden, ed. 5: 67

C. flava L. $\times$ C. lepidocarpa Tausch

Synonyms: - C. pieperiana Junge 1904, Verh. Naturwiss. Vereins Hamburg 3(12): 18.

Culms 22.7-81.6 cm high, 0.8-1.2 mm wide (above uppermost cauline leaf). Leaves usually shorter or as long as culm; uppermost cauline leaf 8.7-23.1 cm long and 2-4 mm wide, with sheath of $15-75 \mathrm{~mm}$ long; basal leaves $14-35.5 \mathrm{~cm}$ long, 3-5 mm wide. Inflorescence 2.9-9.7 cm long. Male spike single, terminal, 5-26 mm long, 1-2 mm wide, sessile or on peduncle of up to $18 \mathrm{~mm}$ long; male glumes 3.4-4.4 mm long, $1.3-2.3 \mathrm{~mm}$ wide, brown with pale midrib region and hyaline margin. Female spikes 1-3, usually close together, ellipsoid, ellipsoid-spherical or ellipsoid-terete, 7-15 mm long, 7-10 mm wide, sessile or lowest spike on peduncle of up to $13 \mathrm{~mm}$ in length. Lowest female spike bract usually longer than inflorescence, $3.9-15.9 \mathrm{~cm}$ long, 1-3 mm wide, bract sheath 1-8 $\mathrm{mm}$ long; bract of second female spike $0.5-5.9 \mathrm{~mm}$ long, usually $1 \mathrm{~mm}$ wide or narrower, sheathless. Utricles 4.0-4.9 mm long, 1.1-1.9 mm wide, gradually tapering into curved, bifid beak, scabrous or sometimes smooth; beak 1.5-2.1 mm long (accounting for $37-45 \%$ of total utricle length). Female glumes 1.7-3.1 mm long, 1.2-1.7 mm wide, dark brown with green midrib region and narrow hyaline margin, obtuse or acute at apex, variable.

Carex $\times$ schatzii Kneuck. 1891, in Seubert, Excurs. Fl. Baden, ed. 5: 67

C. lepidocarpa Tausch $\times$ C. viridula Michaux

Culms 13.9-38.5 cm high, 0.6-1.2 mm wide (above uppermost cauline leaf). Leaves usually shorter than culm, less often as long or longer than culm; uppermost cauline leaf 3.7-20.1 cm long and 2-3 mm wide, with sheath of 10-65 mm long; basal leaves 6-29 cm long, 2.7-5 mm wide. Inflorescence $2.6-12.2 \mathrm{~cm}$ long. Male spike single, terminal, 10-19 mm long, 1-2 mm wide, sessile or on peduncle of up to $40 \mathrm{~mm}$ long; male glumes 2.8-3.9 mm long, 1.4-2.0 mm wide, light to dark brown, with pale midrib region and narrow hyaline margin. Female spikes 1-3(4), usually close together, ellipsoid or nearly spherical, 8-14 mm long, 6-8 mm wide, sessile or lowest spike on peduncle of up to $32 \mathrm{~mm}$ in length. Lowest female spike bract usually as long as inflorescence, $1.8-21.7 \mathrm{~cm}$ long, 1-2.5(3) $\mathrm{mm}$ wide, bract sheath 1-30 mm long; bract of second female spike 0.6-5.4 mm long, up to $1 \mathrm{~mm}$ wide, sheathless. Utricles 2.8-3.9 mm long, $0.8-1.3 \mathrm{~mm}$ wide, gradually tapering into straight, smooth, bifid beak; beak 0.8-1.6 mm long (accounting for $24-40 \%$ of total utricle length). Female glumes 2.0-2.9 mm long, 1.2-1.8 mm wide, dark brown with green midrib region and narrow hyaline margin, obtuse or acute at apex, variable.

Carex $\times$ subviridula Fernald 1933, Rhodora 35: 231

C. flava $\mathrm{L} . \times$ C. viridula Michaux

Synonyms: - C. ×mixta Corbière 1894, Nouv. Fl. Normandie: 607.

Culms 18.9-56.9 $\mathrm{cm}$ high, 0.7-1.2 mm wide (above uppermost cauline leaf). Leaves usually shorter or as long as culm; uppermost cauline leaf 7.5-21.6 cm long and 2-3 mm wide, with sheath of 5-60 mm long; basal leaves $10-35 \mathrm{~cm}$ long, 3-4.5 $\mathrm{mm}$ wide. Inflorescence 2.2-13.5 cm long. Male spike single, terminal, 9-20 mm long, 1-2 mm wide, sessile or on peduncle of up to $10 \mathrm{~mm}$ long; male glumes $3.2-3.9 \mathrm{~mm}$ long, $1.5-1.9 \mathrm{~mm}$ wide, dark brown with pale midrib region and hyaline margin. Female spikes 2-5, usually close together or lowest distant from others, ellipsoid or nearly spherical, 7-14 mm long, 6-9 mm wide, sessile or rarely lowest spike on peduncle of up to $13 \mathrm{~mm}$ in length. Lowest female spike bract usually longer than inflorescence, 4.9-16.8 cm long, 2-3 mm wide, bract sheath 2-42 $\mathrm{mm}$ long; bract of second female spike 2.4-11.7 mm long, 1-3 mm wide, sheathless. Utricles 3.3-3.9 mm long, $1.0-1.5 \mathrm{~mm}$ wide, gradually tapering into straight, scabrous (with sparse bristles) or smooth, bifid beak; beak 1.2-1.6 mm long (accounting for 35-41\% of total utricle length). Female glumes $2.3-2.7 \mathrm{~mm}$ long, 1.2-1.5 mm wide, light to dark brown with green midrib region and narrow hyaline margin, obtuse or acute at apex, variable.

\section{Carex demissa Hornem. $\times$ Carex viridula Michx.}

Culms 19.1-29.4 cm high, 0.6-1.2 mm wide (above uppermost cauline leaf). Leaves usually shorter than culm; uppermost cauline leaf 7.7-12.4 cm long and 2-3 mm wide, with sheath of 5-30 mm long; basal leaves $6-18 \mathrm{~cm}$ long, $2.5-3 \mathrm{~mm}$ wide. Inflorescence 4.6-16.4 cm long. Male spike single, terminal, 13$20 \mathrm{~mm}$ long, 1-2 mm wide, on peduncle of 2-15 mm 
long; male glumes 3.3-3.6 mm long, 1.5-1.7 mm wide, brown with pale midrib region and narrow hyaline margin. Female spikes 2-4, usually close together, or lowest distant from others, ellipsoid or nearly spherical, 7-13 mm long, 5-7 mm wide, sessile or lowest spike on peduncle of up to $6 \mathrm{~mm}$ long. Lowest female spike bract usually as long as inflorescence, 7.9-11.9 cm long, 2-3 mm wide, bract sheath 5-20 mm long; bract of second female spike 4.2-5.8 mm long, 1-2 mm wide, sheathless. Utricles 2.9-3.8 mm long, 0.8-1.3 mm wide, gradually tapering into straight, smooth or scabrous, bifid beak (with sparse bristles); beak 0.9-1.2 mm long (accounting for $28-38 \%$ of total utricle length). Female glumes 2.3-2.8 mm long, 1.3-1.8 mm wide, dark brown with green midrib region and narrow hyaline margin, obtuse or acute at apex, variable.

\section{Discussion}

\subsection{Species concept and delimitation of taxa}

This study is based on the phenetic species concept (Sokal \& Crovello 1970; Sneath \& Sokal 1973). It is generally consistent with the concepts used by taxonomists from northern Europe (Du Rietz 1930; Hedrén 2002), suggesting that species can be separated on the basis of at least 2 morphological characters or a set of characters that are genetically or evolutionarily independent. Species, as a morphological-systematic unit, has specific morphological characters that determine its systematic position. Morphological characters are usually products of a long history of natural selection and a phenotypic reflection of genotype (Kaźmierski 2004). In angiosperm taxonomy, morphological distinctness is still the dominant criterion of identification, verification, and description of individual species (Latowski 2004). This results primarily from the International Code of Nomenclature, including the principle of typification and the principle of priority. Morphological characters are often variable, but their variability can be objectively classified by the use of numerical taxonomy methods. These methods can be used to distinguish taxa on the basis of their morphological similarity (Sneath \& Sokal 1973).

Results of this study show morphological distinctness of taxa included in C. flava agg., very much like results presented by Scandinavian researchers (Palmgren 1959; Hedrén 1990, 1996, 1998, 2002, 2004; Pykälä \& Toivonen 1994; Hedrén \& Prentice 1996). The most important for delimitation of these taxa were the least variable reproductive characters, i.e. length of utricle and its beak, and ratio of beak length to total utricle length. Among other characters, the most important were: bract length and width, length (or absence) of peduncles of male spikes, and number and arrangement of female spikes. In literature there are, however, reports on variation in spike distribution and arrangement of male and female flowers within C. flava s.s., depending on environmental conditions, especially on temperature and photoperiod (Heide 2004). Thus some researchers, when considering taxa of the C. flava complex, do not take into account measurements of inflorescence characters, especially estimation of distance between female spikes (Blackstock \& Ashton 2010). In this study, these characters were included in statistical analyses in spite of their relatively high variability. The measurements are useful if spike distribution is considered in the whole complex, e.g. in specimens of C. demissa, the lowest spike is usually basal, while in specimens of $C$. viridula, female spikes are close together. During field research, in some sedge populations of the C. flava group, some anomalies in floret distribution within spikes were observed. Within male spikes, especially in their uppermost or central parts, female florets were found, whereas within female spikes, most frequently at the apex, some male flowers were present. Occurrence of abnormally developed spikes in sedges is also known from literature and is more often observed in hybrids than in the pure species (see Vonk 1979; Heide 2004). Specimens with such anomalies in spikes were excluded from statistical analyses.

The analysed taxa differed primarily in mean values of characters, whereas ranges of their values usually overlapped between all the distinguished taxa. In spite of the anomalies and observed relatively high variability of many characters, it was possible to identify taxa of the C. flava complex to the species level.

Thus results of this study confirm the taxonomic concept that distinguishes $C$. flava, and especially C. lepidocarpa, $C$. demissa, and $C$. viridula as separate species. This concept is based on (i) a high observed level of morphological separation of these taxa; (ii) integrity of these taxa at the sites where they coexist (despite the presence of intermediate forms resulting from hybridization); and (iii) habitat preferences of individual taxa, especially of C. lepidocarpa in contrast to C. demissa. Thus in Poland the analysed taxa are morphologically well-defined and show clear ecological preferences.

Among members of the $C$. flava complex, C. viridula is characterized by the highest phenotypic plasticity (Więcław 2011; Więcław \& Podlasiński 2013). In this study, according to definitions of form, variety, and subspecies by Du Rietz (1930), the 2 subgroups of C. viridula were treated as local variants of species, i.e. varieties (local or ecological race, ecotype). Varieties can be distinguished because some local populations of the same species differ in several morphological characters, usually presence of qualitative characters (e.g. ratio of fruit size to utricle size), which deviate from the typical variety and may form ecotypes (Turesson 1922). As emphasized by Hedrén (2002), individual 
varieties may differ in habitat preferences, so there is still a need to distinguish them. It can be hypothesized that extreme forms of $C$. viridula have developed locally in response to different selection pressure (Schmid 1984b).

In northern Europe, on the basis of utricle size, $C$. viridula is divided into 3 varieties, without any clear hiatus. Within populations of $C$. viridula continuous variation is observed, and specimens reaching extreme values are usually classified as different varieties (Schmid 1983). The smallest variety, $C$. viridula var. pulchella, has small and narrow utricles, completely filled by fruits. In Poland it was found in salt marshes along the Baltic coast (Zając 1968), but currently it seems to be absent there. C. viridula var. bergrothii, endemic to northern Europe, has the largest utricles, whereas the most common C. viridula var. viridula has medium-sized utricles (Hedrén 1998; Pykälä \& Toivonen 1994).

Local populations with values of morphological characters intermediate between these 3 varieties are quite common in Scandinavia and Poland, so delimitation of varieties on the basis of morphological characters is not clear and unambiguous (Zając 1968; Pykälä \& Toivonen 1994). In Poland, ranges of values of utricle characters of var. viridula and var. pulchella overlap. According to Zając (1968), utricle and beak are 1.9$2.8 \mathrm{~mm}$ and 0.2-0.6 mm long, respectively, for the typical variety, and $1.1-3.0 \mathrm{~mm}$ and $0.2-0.8 \mathrm{~mm}$ for var. pulchella. For comparison, Palmgren (1959) reported utricle length of (2.1)2.5-3.5 mm for var. viridula and (1.8)2-2.5(2.9) for var. pulchella, while according to Davies (1953a, c) in var. viridula utricles are (1.7)2.0$2.5(3) \mathrm{mm}$ long and beaks are $0.25-0.5 \mathrm{~mm}$ long, whereas in var. pulchella their length is much lower: utricle (1.0)1.5-2.5 mm long and beak up to $0.25 \mathrm{~mm}$ long. A major character for distinguishing between these varieties is the ratio of fruit size to utricle size, i.e. the degree of filling the utricle body by the fruit (e.g. Havlícková 1982; Pykälä \& Toivonen 1994; Egorova 1999). Usually in the typical variety the fruit fills $2 / 3$ to $3 / 4$ of the utricle body, while in var. pulchella the fruit completely fills the utricle body. The ratio can be calculated only for fully developed plants. Within a local population, individuals at various stages of development are found, so it is difficult to determine unambiguously (for the whole population) the true ratio of fruit size to utricle size, i.e. the degree of filling the utricle body by the fruit. This character is also less valuable for analysis of dried material; herbarium specimens often include plants with immature utricles, and their imbibition also does not give satisfactory effects. For varieties of C. viridula, information about habitat seems crucial, since specimens of var. pulchella are usually found in salt marshes along sea coasts (e.g. Chater 1980; Hedrén 2002).
C. viridula var. pulchella and C. viridula var. bergrothii were treated by some taxonomists as species, namely $C$. pulchella $(=C$. scandinavica) and C. bergrothii, respectively (Davies 1953a, 1953c; Egorova 1999) or as subspecies: C. viridula subsp. pulchella and C. viridula subsp. bergrothii, respectively (see Palmgren 1959; Chater 1980). The present detailed morphological study of Polish individuals indicates a lack of hiatus between individuals of $C$. viridula (var. viridula and var. pulchella), so it is not justifiable to treat them as separate species. Populations of C. viridula (var. viridula and var. pulchella) form a mosaic within their range of distribution, so it is impossible to distinguish geographic variants (geographic races) (Hedrén 2002). However, they occupy various adaptation zones, so varieties of $C$. viridula can be regarded as so-called ecological species (van Valen 1976), although they are not a strictly monophyletic unit (Hedrén 2004).

Classification of the C. flava group is still subject to discussions, usually concentrating on 2 major approaches: synthetic and analytic, i.e. 1-2 biological species versus 4 morphological species (Jiménez-Mejías et al. 2012a). The synthetic approach, which fuses C. lepidocarpa, C. demissa, and C. oederi into one species, named $C$. viridula s.1., presented by Schmid (1983), is still controversial and does not reflect fully the complex pattern of variation within this group (Hedrén 1990, 2002, 2004; Pykälä \& Toivonen 1994). Schmid (1983) suggested that in the $C$. flava complex the relative biological species concept should be used, basing on hybrid viability, and distinguished 2 species on this basis: $C$. flava s.s. and C. viridula s.1. In fact, C. flava s.s. crosses with all plants of the $C$. flava group but the hybrids are characterized by very low fertility, i.e. $0-3 \%$ of fertile pollen and variable seed set (Schmid 1982). According to Schmid (1983), such a low level of viability observed in the hybrids justifies distinguishing of C. flava as a separate species. By contrast, $F_{1}$ plants resulting from hybridization between the other members of the complex are characterized by partly reduced fertility: about $30 \%$ of pollen grains are fertile and $10-25 \%$ of seeds are well developed (Schmid 1982). According to the biological species concept used by Schmid (1983), the observed lowered fertility of these hybrids did not provide sufficient evidence to distinguish C. lepidocarpa, C. demissa, and C. viridula as separate species, although these taxa could be distinguished in the field (Schmid 1986a). An even more radical taxonomic approach to $C$. flava agg., consistent with the strict biological concept, was proposed by Sell (1996). Because of the lowered fertility of forms intermediate between C. flava s.s. and other members of this group, he distinguished only one species, namely C. flava s.1., and classified all the others as subspecies. 
The material collected for this study included also specimens that were morphologically intermediate between pure species and varied widely in percentage of well-developed fruits (from completely sterile plants to some having well-developed fruits in $>50 \%$ of utricles). These plants could represent both $\mathrm{F}_{1}$ hybrids and backcross hybrids. Some partly fertile specimens were morphologically intermediate between $C$. flava s.s. and other taxa, which suggests that introgression between them is possible. Thus, if the biological species concept was used, it would be justified to fuse all the analysed taxa into one species, as suggested by Sell (1996). However, application of the biological species concept in plants, where hybridization in common, would lead to classifying of morphologically divergent entities as one species, which could be composed of independent evolutionary lines (Hedrén 2002). Such an approach could lead to a remarkable decrease in number of plant species and fusion of well-defined and unproblematic taxa (Grant 1981; Stace 1989).

All the species distinguished in this study cross with one another but most plants from mixed populations, where at least 2 species of the C. flava group occur sympatrically, can be identified to species level, which can be regarded as an empirical test for delimitation of pure species (Grant 1981; Hedrén 2002). Mixed populations were often found in Sweden, Norway, Finland, Estonia, and Switzerland, where also most plants could be identified to species level (Schmid 1981; Hedrén 2002). In the British Isles, coexistence of 2 or more species at the same site is observed less frequently (Davies 1956; Wallace et al. 1975; Sell 1996), very much like in North America (Crins \& Ball 1989a, 1989b), where hybridization between taxa of the C. flava group has been relatively poorly studied.

Taxonomic research on the genus Carex, especially of critical groups, such as the C. flava group, should be conducted in relation to biology and ecology of populations in the field. Only such field research can be supplemented with analysis of herbarium material. According to conventional Linnaean taxonomy, the subject of taxonomic research should be a real species, which in the field is an identifiable entity with specific ecological preferences, characterized by distinct biology and a specific range of distribution (Bachmann 1995; Mitka 2004).

Conventional taxonomy is not limited to research on exomorphic characters. On the contrary, it is aimed to construct classification systems based on a comprehensive data set, including also endomorphic characters (Mitka 2004). Simultaneous allozymatic and morphological research conducted in the C. flava group shows that taxa of this group are in fact better separated than it appeared on the basis of morphological analysis alone (Hedrén 2002; Blackstock 2007). Thus allozymatic research confirms even more clearly the validity of the analytic approach to the C. flava complex, which indicates that 4 morphological species exist.

In many cases, molecular research is obviously necessary, e.g. in cryptic species, which are morphologically identical but isolated reproductively; thus they are real species in the light of the biological species concept (Odrzykoski 2004). Besides, molecular studies provide important additional information necessary for more precise interpretation of the taxonomic status of complex plant groups (López \& Morrone 2012).

Results of preliminary molecular research (JiménezMejías et al.2012a) on taxa of the section Ceratocystis, including taxa of the $C$. flava group, are consistent with results of their morphological analysis, confirming the validity of distinguishing $C$. lepidocarpa, $C$. demissa, and $C$. viridula as separate species. The resultant rps 165 trn $K$ phylogenesis corresponds to the general division of species of the $C$. flava complex into those with a curved beak (C. flava s.s., C. lepidocarpa) and those with a straight beak $(C$. demissa, $C$. viridula) (e.g. Chater 1980; Egorova 1999; Crins 2002), which are grouped as separate clades (Jiménez-Mejías et al. 2012a).

Taxa of the C. flava complex are relatively poorly distinguished on the basis of chromosome number. Different chromosome numbers are reported for both C. flava s.s. and C. lepidocarpa: 5 and 7 cytotypes, respectively (Rotreklová et al. 2011). For C. flava s.s., according to literature, the usual chromosome number is $2 n=60$, less often $2 n=56,58,64$, and 70 (Davies 1955; Schmid 1982; Stoeva \& Štěpankova 1990; Halkka et al. 1992; Luceño 1994; Roalson 2008; Hipp et al. 2009; Rotreklová et al. 2011). For C. lepidocarpa, usually $2 n$ $=68$, less often $2 n=58,62,66,69,70$, and 72 (Davies 1955; Schmid 1982; Stoeva \& Štěpankova 1990; Luceño 1994; Rotreklová et al. 2011). The chromosome number indicates a close relationship between $C$. demissa and $C$. viridula, as in both taxa it is $2 n=68$ and 70 , so it is impossible to conclude about their separation on the basis of cytological data (Davies 1955; Schmid 1982; Stoeva \& Štěpankova 1990; Halkka et al. 1992; Luceño 1994; Roalson 2008; Rotreklová et al. 2011). Chromosome numbers in varieties of $C$. viridula are also similar: for var. bergrothii and var. pulchella $2 n=$ 70 , while for var. viridula $2 n=68,70,72$ (Halkka et al. 1992).

In relation to the $C$. flava group, various taxonomic concepts have been used, but there is a general consensus about relationships between them, as similar patterns of variation are observed in various parts of Europe (e.g. Schmid 1982; 1986a; Pykälä \& Toivonen 1994; Hedrén 2002). C. flava s.s was always regarded morphologically as most distinct, which is also confirmed by my research on Polish specimens of sedges. The greatest similarity is noticeable between varieties of $C$. viridula, 


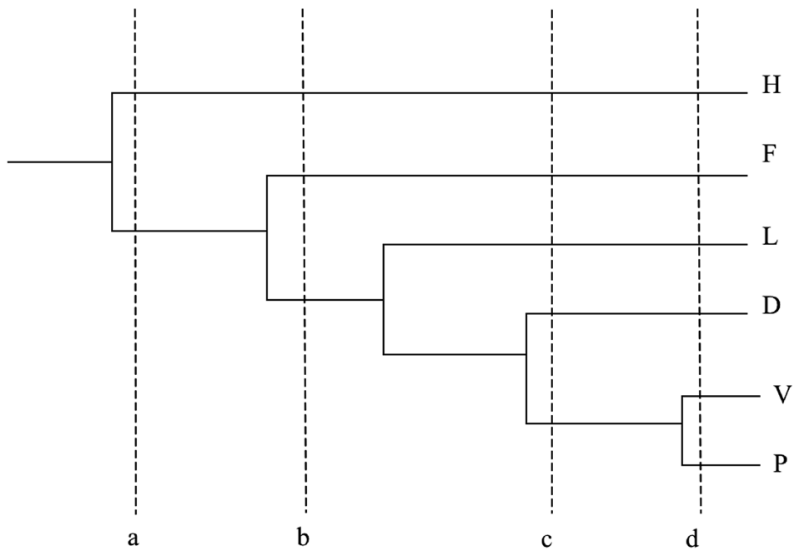

Fig. 11. Summary of classifications and phylogenetic links within the section Ceratocystis (including the Carex flava group and $C$. hostiana) according to Hedrén (2004), modified to match the situation observed in Poland

Explanations: a-biological species concept, only 2 species, hybrids between them completely sterile (Sell 1996), b - relative biological species concept, based on the level of hybrid viability, 3 species (Schmid 1982, 1983; Crins \& Ball 1988), c-morphological species concept, 5 species (Pykälä \& Toivonen 1994; Hedrén 2003; Blackstock 2007), d - ecological species concept, 6 species (Davies 1953a; Palmgren 1959; Egorova 1999), D - C. demissa, $\mathrm{F}-$ C. flava s.s., $\mathrm{H}-$ C. hostiana, $\mathrm{L}-$ C. lepidocarpa, $\mathrm{P}-$ C. viridula var. pulchella, $\mathrm{V}-$ C. viridula var. viridula

especially var. viridula and var. pulchella (e.g. Hedrén 2002). Because of the lack of clear discontinuities between varieties and the great variability of $C$. viridula, many authors have opposed to distinguishing these taxa and maintenance of infraspecific ranks (Crins \& Ball 1989b; Jermy et al. 2007). Some researchers emphasize the absence of clear separation between $C$. viridula and C. demissa (Bruederle \& Jensen 1992), but most authors regard them as separate taxa (e.g. Schmid 1981, 1983; Pykälä \& Toivonen 1994; Egorova 1999; Koopman 2011). Phylogenetic links within the C. flava complex were discussed by Schmid (1982), Crins \& Ball (1988), and Hedrén (2002) (Fig. 11).

\subsection{Natural hybridization}

Hybridization is more or less frequent among vascular plants. Spontaneous hybrids recurring and surviving in natural conditions are the driving force of plant speciation (e.g. Barton \& Hewitt 1989; Rieseberg 1995, 1997; Arnold 1997; Barton 2001; Wissemann 2005). Members of the C. flava group often coexist at the same site and in the direct contact zone usually hybrids are present, composed of $\mathrm{F}_{1}$ plants and their offspring resulting from backcrosses to parental taxa (Schmid 1982, 1986). Schmid (1982) suggests that critical groups of sedges, e.g. those of the section Ceratocystis (including C. flava group) are currently in the dynamic phase of evolution. In relation to a taxon endemic to Scandinavia, C. viridula var. bergrothii, a hypothesis of hybrid origin has been considered (Hedrén 1990, 1998). The hypothesis that this taxon results from hybridization and introgression (between C. viridula s.l. and C. lepidocarpa s.1.) is confirmed by a situation observed by Hedrén (1990) at several natural sites in Scandinavia, where putative parental taxa (C. lepidocarpa subsp. jemtlandica, endemic to Scandinavia, and C. viridula var. viridula) coexisted with $C$. viridula var. bergrothii and sterile specimens of $C$. lepidocarpa $\times C$. viridula; but the last 2 taxa were morphologically very similar and intermediate between pure C. lepidocarpa subsp. jemtlandica and C. viridula var. viridula (Hedrén 1990).

In Poland some populations are also mixed, composed of 2 or rarely 3 species of the C. flava complex as well as numerous morphologically intermediate specimens. The most frequently coexisting species were C. flava and C. demissa, accompanied by completely sterile specimens of $C$. $\times$ alsatica. The hybrid was morphologically similar (but not identical) to C. flava or intermediate between both parental species. Similarity to $C$. flava was determined primarily by vegetative characters, and, to a lesser extent, dimensions of utricle and beak (in most specimens of hybrid of intermediate size, but tending to reach the dimensions of utricles and beaks of C. flava) and size of female spikes. Blackstock \& Jermy (2001) reported that specimens of $C$. $\times$ alsatica found in Britain were also sterile and similar both to immature C. flava and to large atypical C. demissa, having elongated inflorescences with female spikes clustered around the male spike, like in C. flava. In one locality in northern Poland, specimens of $C$. $\times$ alsatica occasionally had a similar arrangement of female spikes as that observed in C. demissa (lower spike located below half the length of the culm). Sterility of C. flava $\times$ C. demissa was confirmed by research conducted by Schmid (1982) in Switzerland (pollen fertility in artificial hybrids did not exceed 1\%). However, Davies (1955) found that pollen fertility in natural hybrids $C$. flava $\times$ C. demissa from the British Isles reached 22\%.

Similar differences in pollen fertility were noticed also in hybrid specimens of C. flava $\times$ C. lepidocarpa . According to Schmid (1982), specimens of $C$. xruedtii from Switzerland were characterized by low pollen fertility, of up to $2 \%$ (in artificial hybrids up to $3 \%$ ), whereas according to Davies (1955), pollen fertility in specimens from British Isles reached 29\%. In Poland, completely sterile specimens of $C$. xruedtii were recorded as well as plants having usually several to about a dozen per cent of utricles with well-developed fruits. The specimens of hybrid were morphologically similar to C. lepidocarpa or their morphological characters were intermediate between both parental taxa, e.g. length of utricle and beak, or length and width of the lowest female spike bract. At all the localities where hybrids appeared, most of the plants were classified as pure $C$. lepidocarpa, whereas specimens of $C$. flava 
s.s. were infrequent and found only at the edges of habitats. Blackstock \& Ashton (2010), who studied a population of C. flava $\times$ C. lepidocarpa in Britain, also observed a high morphological similarity of $C$. x ruedtii and $C$. lepidocarpa, but the hybrids coexisted with a population of pure C. lepidocarpa, whereas C. flava was absent. It seems that the hybrid, despite a low level of pollen fertility, will form backcrosses with $C$. lepidocarpa, which is more common in the studied Polish localities (than the infrequent C. flava), or like in Britain, with one parental taxon present at the same site (Blackstock \& Ashton 2010).

Specimens of $C$. xschatzii are usually intermediate between both parental taxa or more similar to C. lepidocarpa. In utricles of some specimens, fruits were normally developed (sometimes even more than $50 \%$ of utricles with well-developed fruits), so they may be $\mathrm{F}_{\mathrm{n}}$ hybrids or backcrosses, which would attest to the possibility of introgression towards $C$. lepidocarpa. Schmid (1982) reported that in artificial hybrids C. lepidocarpa $\times$ C. viridula, seed set varied from $6 \%$ to $12 \%$, while pollen fertility, from $25 \%$ to $37 \%$. Schmid (1982) did not study the fertility of natural hybrids but supposed that they may be less fertile than hybrids produced in laboratory conditions. Davies (1955) assessed the fertility of natural hybrids C. lepidocarpa $\times$ C. viridula from 2 British localities, where it reached $20 \%$ and $25 \%$, respectively. Interestingly, the parental species differ very much in flowering season. C. lepidocarpa flowers the earliest among all members of the analysed group, whereas $C$. viridula flowers the latest (Vonk 1979). However, their flowering period may overlap and sometimes late-flowering populations of C. lepidocarpa may start flowering at the same time or even later than the earliest-flowering populations of $C$. viridula (Vonk 1979). Besides, flowering season depends on environmental factors, including temperature and photoperiod, as shown in controlled conditions by Heide (1997). Consequently, spontaneous crossing of these species is possible, so the resultant partly fertile hybrids will probably most often cross back with specimens of $C$. lepidocarpa, which are then at the height of the flowering season, rather than with specimens of $C$. viridula, which only start to flower.

Specimens of $C$. demissa $\times C$. viridula are partly fertile and morphologically very similar to C. demissa. In artificial hybrids, seed set ranged from $18 \%$ to $25 \%$ (Schmid 1982), whereas pollen fertility in natural hybrids reached 29\% (Davies 1955). C. demissa starts flowering as the third species of the C. flava group, whereas - as mentioned earlier - C. viridula, is the latest flowering species (Vonk 1979). Thus introgression will probably be directed towards $C$. demissa.

During phenetic analysis, a group of OTUs, represented by sterile herbarium specimens, filled the space between $C$. flava and C. viridula. These specimens were classified as $C . \times$ subviridula. In herbarium material originating from the same sites, both the above-mentioned hybrid were found as well as potential parental taxa, i.e. C. flava and C. viridula. This hybrid had characters common to both putative parents or some specimens were more similar to the tall C. viridula. Pollen fertility of natural hybrids $C$. flava $\times C$. viridula in Swiss sedge populations varied from $2 \%$ to $7 \%$ (Schmid 1982).

C. demissa and C. lepidocarpa coexisted only at one site in West Pomerania and did not form hybrid. Herbarium material did not include hybrid between these taxa either. It seems that in Poland these are environmentally the most isolated taxa among members of the C. flava complex.

Within the section Ceratocystis, some hybrids between $C$. hostiana and members of the $C$. flava group have been found (Kiffe 2001; Koopman 2010; Więcław \& Koopman 2013). The hybrids were completely sterile (see Davies 1955; Schmid 1982), more or less similar to $C$. hostiana or morphologically intermediate between parental forms. All hybrids had a characteristic white membrane at the beak apex and female glumes with wide transparent margins, like in C. hostiana (Crins \& Ball 1987; Egorova 1999; Blackstock \& Jermy 2001). In herbarium material some specimens were completely sterile and filled the phenetic space between C. hostiana and members of the C. flava group. One group of OTUs was intermediate between $C$. hostiana and $C$. lepidocarpa, while another group of OTUs was intermediate between $C$. hostiana and $C$. demissa, so the specimens were classified as hybrids: $C . \times$ leutzii and $C$. xfulva, respectively (Więcław \& Koopman 2013). Contrasting views can be found in literature on nomenclature of the hybrids and their putative parents of the C. flava group. Wallace et al. (1975) report that C. $\times$ fulva is a cross between C. hostiana and C. lepidocarpa, whereas Koopman $(2010,2011)$ states that the parents are $C$. hostiana and $C$. demissa. The reason for the confusion about nomenclature of hybrids between C. hostiana and C. flava agg. was the material collected by Goodenough, who on this basis described C. fulva as a species in spite of sterility of the analysed specimens (Crins \& Ball 1987; Cayouette \& Catling 1992). Actually, the material included very probably both hybrids: $C$. hostiana $\times C$. demissa and C. hostiana $\times C$. lepidocarpa (Koopman, pers. comm.). Besides, specimens of $C$. demissa $\times C$. hostiana are very similar to $C$. hostiana $\times$ C. lepidocarpa, and according to Wallace et al. (1975) they can be distinguished only on the basis of spike size (spikes are narrower and slightly shorter than in hybrid of C. demissa). A study conducted by Więcław \& Koopman (2013) shows that specimens of $C$. $\times f u l v a$ have shorter utricles, male spikes on longer peduncles, 
and narrower female spikes, usually more distant from one another than in specimens of $C$. ×leutzii. Another significant difference is also the ratio of beak length to total utricle length, which is higher for $C$. $\times$ fulva than for $C$. $\times$ leutzii. Finally, C. $\times$ fulva grows in more or less compact tufts, like $C$. demissa, whereas $C$. ×leutzii grows in very loose tufts, more like $C$. hostiana.

Natural hybrids within the section Ceratocystis can be identified on the basis of their complete sterility or partial fertility, presence of intermediate characters and characters of either of the parental species. Important characters for delimitation of hybrids include dimensions of utricle and beak, and ratio of beak length to utricle length. Most of the analysed morphological characters in hybrids have values intermediate between the parental species, so it is difficult to indicate characters specific to hybrids except their reduced fertility, reflected in the presence of empty utricles. However, a general trend can be observed: utricle length and beak length in hybrids are usually closer to that recorded in the parent with longer utricles and beaks. Thus specimens of $C$. xruedtii, and especially of C. xalsatica, have relatively long utricles and beaks, which in many specimens of $C$. xalsatica reach even the same dimensions as in pure C. flava. Similarly, values of these characters in $C$. demissa $\times C$. viridula corresponds to dimensions recorded in pure C. demissa (Więcław \& Wilhelm 2014).

The length of utricle and beak in hybrids between C. hostiana and the members of C. flava agg. is strongly related to values of these characters in parental taxa of the $C$. flava complex. Utricle length declines in the following order: C. ×xanthocarpa (C. flava as a parent), C. $\times$ leutzii (C. lepidocarpa as a parent), and C. $\times$ fulva (C. demissa as a parent). Ratio of beak length to utricle length is high for $C$. $\times$ fulva (like for C. demissa) and low for $C$. $\times$ leutzii (like for C. lepidocarpa) (Więcław \& Koopman 2013).

Useful for delimitation of hybrids of the C. flava complex are also field data, i.e. coexistence of putative parental species and hybrids. It is much more difficult to identify hybrids if one (or even both) parental species no longer exist at the same site and if putative hybrids are fertile to a large extent and have well-developed fruits. In such a situation, determination of hybrid origin of sedges of the C. flava group requires molecular analyses. Schmid (1982) described them as stabilized cryptic backcrosses, as they can be distinguished only on the basis of genetic research.

\subsection{Ecological preferences}

Carex viridula has the widest ecological niche among members of the C. flava complex, and is characterized also by the highest phenotypic plasticity (Schmid 1984a). It colonizes various types of sites, from organic to sandy, from acidic to alkaline, usually humid but sometimes growing on flooded or periodically dry sites (see Davies 1956; Schmid 1984b; Crins \& Ball 1989b). Vonk (1979) showed that within the C. flava group, only specimens of $C$. viridula are able to flower as early as in the first growing season. Schmid (1984b, 1986b) observed a high survival rate at the germination stage and earlier maturity of specimens of $C$. viridula than of $C$. flava. Populations of $C$. viridula are thus characterized by a broad range of tolerance to diverse and variable environment, as well as fast development, potential for early and fast reproduction, relatively low and variable population size, and short life cycle (Schmid 1984a, 1984b; Vonk 1979).

Carex viridula usually grows in open habitats in our country, and poorly competes with other plant species (see Davies 1956). A broad range of $\mathrm{pH}$ values recorded at its sites suggests that soil $\mathrm{pH}$ does not limit its occurrence. In Poland, $C$. viridula grows on soils with $\mathrm{pH}$ ranging from 4.2 to 8.1 , like in Bulgaria and former Czechoslovakia ( $\mathrm{pH}$ 4.7-8.3; Stoeva \& Štepánková 1990), in the British Isles (pH 5.4-8.5; Davies 1956), Switzerland (pH 6.3-8.2; Schmid 1984b), and North America (pH 5.2-7.6; Crins \& Ball 1989a).

Carex lepidocarpa prefers calcareous sites, with $\mathrm{pH}$ 5.5-7.9 (mean 7.0). In Poland, C. lepidocarpa, usually grows on moist, calcareous meadows and fens, rarely in intermediate mires (poor fens). In Switzerland the taxon was recorded on soils with $\mathrm{pH}$ 6.8-8.2 (Schmid 1984a), compared to $\mathrm{pH} 5.8-8.2$ in the British Isles, (Davies 1956) and pH 6.4-8.3 in Bulgaria and former Czechoslovakia (Stoeva \& Štepánková 1990). Clymo (1962) showed that calciphily of this species is due to its sensitivity to aluminium. Aluminium ions dissolved in the soil with lowered $\mathrm{pH}$ cause injuries to roots of calciphiles (Clymo 1962), including C. lepidocarpa. Besides, this taxon is found on wet sites and is relatively sensitive to lower water level (Pykälä 1994).

Carex demissa usually grows on slightly acidic meadows, marshes, poor fens, along forest roads and paths. The species was found on soils with a wide range of $\mathrm{pH}$ values, from 3.8 to 7.1, but most often on slightly acidic sites (mean pH 4.8). Similarly, in Central Europe C. demissa is usually recorded at acidic sites (Patzke \& Podlech 1960), e.g. at pH 5.1-6.4 in Switzerland (Schmid 1984a) or pH 5.4-6.3 in Bulgaria and former Czechoslovakia (Stoeva \& Štepánková 1990). In the British Isles, it was sporadically found on soils with $\mathrm{pH}$ 7.5 (Davies 1953). In Finland it is even calciphilous, growing on soils rich in nutrients (Pykälä \& Toivonen 1994). According to Pykälä \& Toivonen (1994), the distribution of $C$. demissa in Finland reflects the known phenomenon that species are more demanding at the limits of their distribution ranges. In Poland, C. demissa grew on soil with $\mathrm{pH}>7$ at only one, the northernmost 
site (near the town of Kołobrzeg), about $700 \mathrm{~m}$ from the Baltic coast. At the other sites, $\mathrm{pH}$ varied from 3.9 to 6.7. This species tolerates aluminium ions dissolved in the soil (Clymo 1962). It can survive at sites with lowered $\mathrm{pH}$, i.e. where other species of the C. flava group, especially C. lepidocarpa, die because of aluminium sensitivity (Clymo 1962).

Carex flava s.s. is found on moist meadows, wetlands and marshes, roadsides, in ditches, and alder thickets and woods. In Poland it grows on soils with a wide range of $\mathrm{pH}$, from 3.8 to 7.6 , but prefers slightly alkaline sites (mean $\mathrm{pH}$ 5.9). In other European countries, soil $\mathrm{pH}$ at sites of C. flava was higher than in Poland, e.g. 6.8-8.2 in Switzerland (Schmid 1984a), or 5.2-8.3 in Bulgaria and former Czechoslovakia (Stoeva \& Štepánková 1990). In the British Isles, C. flava is rare, and soil pH was measured at only 2 sites, where it amounted to 6.5 on average (Davies 1956). In North America, C. flava is found on moist or wet sites, usually with a high concentration of calcium cations and $\mathrm{pH}$ 5.8-8.5 (Crins \& Ball 1989a, 1989b).

\section{Final remarks and conclusions}

Numerical analysis of morphological characters in 1852 living specimens of sedges of the Carex flava group collected from 80 localities and in 1500 herbarium specimens from 26 herbaria and 7 private collections made it possible to distinguish 4 species and 7 hybrids. The latter comprise 5 hybrids resulting from hybridization within the C. flava complex, and 2 hybrids resulting from hybridization between members of C. flava agg. and C. hostiana.

The results of this study confirm the taxonomic concept that 4 species can be distinguished within the C. flava group: C. flava s.s., C. lepidocarpa, C. demissa, and $C$. viridula. A high level of morphological separation of these taxa was observed in Poland, reflected mostly in generative characters: length of utricle and utricle beak, as well as percentage ratio of beak length to total utricle length. Other characters useful for delimitation of species include bract length and width, length (or absence) of peduncles of male spikes, and number and arrangement of female spikes. The synthetic approach (associated with the biological species concept, based on the lowered fertility of hybrids), which fuses $C$. lepidocarpa, C. demissa, and C. oederi into one species, named $C$. viridula s.l., does not reflect fully the complex pattern of variation within the C. flava group.

The highest phenotypic plasticity is observed in C. viridula. Continuous variation of morphological characters is noticeable among specimens of this species, so it is not justified to distinguish its subspecies (sometimes classified even as separate species) described earlier in literature. Specimens of $C$. virid- ula were grouped into local variants of species, i.e. varieties: var. viridula and var. pulchella. These taxa differ in habitat preferences: specimens of $C$. viridula var. pulchella are usually found in salt marshes along sea coasts, whereas $C$. viridula var. viridula is common in meadows, marshes, peatlands, edges of lakes, ponds, ditches, roadsides, and in depressions between dunes. The application of molecular methods may allow a more precise determination of intraspecific variability of $C$. viridula in its wide range of morphological variation.

Some local populations in Poland were mixed, composed of 2 or rarely 3 species of the $C$. flava complex, accompanied by numerous morphologically intermediate hybrids. Most frequently coexisting species were C. flava and C. demissa, accompanied by completely sterile speciemens of hybrid. Quite often, coexistence of C. lepidocarpa and C. viridula was observed, but they formed hybrids infrequently, because of differences in flowering season. In Poland, C. lepidocarpa and C. demissa seemed to be ecologically the most isolated taxa of the C. flava group, both during field research and examination of herbarium specimens in the laboratory, no hybrids between these species have been found.

Natural hybrids appearing within the C. flava group and the whole section Ceratocystis can be identified on the basis of their complete sterility or partial fertility, reflected in the high percentage of empty utricles (70-100\% of utricles of hybrids do not contain fully developed fruits) and the presence of intermediate characters or characters of one and the other parental species. Important characters for delimitation of hybrids include dimensions of utricle and beak, and ratio of beak length to total utricle length. Utricle length and beak length in hybrids is usually closer to that recorded in the parent with higher mean values of these characters. For instance, $C$. xalsatica has relatively long utricles and beaks, which in many specimens reach even the same dimensions as in pure C. flava.

In Poland the following hybrids were recorded: C. $\times$ alsatica $[$ C.demissa $\times$ C.flava], C. $\times$ ruedtii [C.fla$v a \times$ C. lepidocarpa], C. $\times$ schatzii $[$ C. lepidocarpa $\times$ C. viridula], C. $\times$ subviridula [C. flava $\times$ C. viridula], C. demissa $\times$ C. viridula, C. $\times$ fulva $[C$. demissa $\times$ C. hostiana], and C. $\times$ leutzii $[C$. hostiana $\times$ C. lepidocarpa]. Hybrids between $C$. hostiana and members of the C. flava group, as well as $C$. $\times$ alsatica and $C$. $\times$ subviridula, were completely sterile, whereas some specimens of $C$. flava $\times$ C. lepidocarpa, C. lepidocarpa $\times C$. viridula, and $C$. demissa $\times C$. viridula were partly fertile. Those plants could be $\mathrm{F}_{\mathrm{n}}$ hybrids or backcrosses, which would indicate the possibility of introgression.

Sites of taxa of the C. flava group differ in $\mathrm{pH}$ and concentrations of $\mathrm{CaCO}_{3}$ and $\mathrm{Ca}$ in the soil. Most significant differences in soil parameters were found between 
sites of C. lepidocarpa (preferring calcareous habitats) and $C$. demissa (usually growing on slightly acidic soils). The widest range of $\mathrm{pH}$ values was recorded at the studied sites of $C$. viridula; it seems that soil $\mathrm{pH}$ does not limit its distribution.

Taxa of the C. flava complex grow on wet or moist sites and are generally (except for $C$. viridula) relatively sensitive to lower water level. These species prefer open habitats, especially C. viridula, which rather poorly competes with other plants growing at the same site.

In Poland, taxa of the C. flava complex are morphologically well-defined and show clear habitat preferences. Most plants from mixed populations, where at least 2 species of the C. flava group occur sympatrically, could be identified unambiguously despite the presence of intermediate forms resulting from hybridization. Other reasons for maintenance of their species rank are provided by ecological analyses, concerning primarily soil $\mathrm{pH}$, water supply, and ecological specialization associated with competition.

Acknowledgements. I would like to express my sincere gratitude to Prof. Adam Zając for help in selection of the subject of my study and for scientific consultations. I thank Bartosz Kurnicki, MSc, for invaluable assistance in field work, and
Jacob Koopman, MSc, for coordination of field research in Switzerland and the Netherlands, and help in analysis of herbarium specimens in Berlin, Leiden, Vienna, and Białowieża. My grateful thanks are also due to Prof. Agnieszka Popiela, Dr Brygida Wawrzyniak-Wydrowska, and Dr Agnieszka Szlauer-Łukaszewska for access to measuring equipment, to Dr Marek Podlasiński for analysis of soil samples, to Dr Marcin Wilhelm and Magdalena Rutkowska, MSc, for help in compiling the lists of localities of the analysed taxa, and to Sylwia Ufnalska for professional translation of the manuscript into English, as well as her valuable comments and advice. I also thank curators of the herbaria listed in the manuscript and owners of private collections, for access to their materials, as well as my colleagues at the Department of Plant Taxonomy and Phytogeography and Department of Botany and Nature Conservation of Szczecin University for their professional support. Finally, I am grateful to the staff of national and landscape parks, for permission to conduct field research in the Maritime Landscape Park (Nadmorski Park Krajobrazowy), Nida Landscape Park (Nadnidziański Park Krajobrazowy), Landscape Park "Międzyrzecze Warty i Widawki”, Barycz Valley Landscape Park (Park Krajobrazowy Doliny Baryczy), Przedbórz Landscape Park (Przedborski Park Krajobrazowy), Wda Landscape Park (Wdecki Park Krajobrazowy), Wdzydze Landscape Park (Wdzydzki Park Krajobrazowy), Załęcze Landscape Park (Załęczański Park Krajobrazowy), Słowiński National Park, Bieszczady National Park, and Karkonosze National Park.

\section{References}

ARNOLD M. L. 1997. Natural hybridization and evolution. 215 pp. Oxford University Press, Oxford.

Bachmann K. 1995. Progress and pitfalls in systematics: cladistics, DNA and morphology. Acta Botanica Neerlandica 44(4): 403-419.

BARTON N. H. 2001. The role of hybridization in evolution. Molecular Ecology 10: 551-568.

Barton N. H. \& Hewitt G. M. 1989. Adaptation, speciation and hybrid zones. Nature 341: 497-503.

Blackstock N. 2007. A re-assessment of the yellow sedges Carex flava agg. (Cyperaceae) in the British Isles. Ph. D. Thesis, University of Lancaster, England.

Blackstock N. \& Ashton P. A. 2001. A re-assessment of the putative Carex flava agg. (Cyperaceae) hybrids at Malham Tarn (v.c. 64): A morphometric analysis. Watsonia 23: 505-516.

Blackstock N. \& Ashton P. A. 2010. Genetic markers and morphometric analysis reveal past hybridization and introgression in putative Carex flava L. s.str. (Cyperaceae) hybrid populations. Plant Syst Evol 287: 37-47.

Blackstock N. \& Jermy C. 2001. Identyfication Yellowsedges Carex flava aggregate. British Wildlife 12(5): 345-351.

Bosiacka B. \& WięcŁaW H. 2012. Carex extensa (Cyperaceae) rediscovered in Poland. Polish Botanical Journal 57(2): 371-374.
Bruederle L. P. \& Jensen U. 1991. Genetic differentiation of Carex flava and Carex viridula in West Europe (Cyperaceae). Syst. Bot. 16: 41-49.

Brzosko E. 1999. The life history of Carex cespitosa: Consequences for population dynamics and vegetation succession. Polish Bot. Studies 14: 3-60.

Brzosko E. 2001. Changes in population structure of Carex cespitosa during 10 years of secondary succession in an abandoned meadow in Białowieża, Poland. Ann. Bot. Fenn. 38: 249-258.

Cayouette J. \& Catling P. M. 1992. Hybridization in the genus Carex with special reference to North America. Botanical Review 58(4): 351-438.

Ceynowa M. 1969. Turzyca poznańska-Carex posnaniensis Sprib. na nowych stanowiskach nad Wisłą. Fragm. Flor. Geobot. 15(2): 173-178.

Chater A. O. 1980. Carex L. In: T. G. Tutin, V. H. Heywood, N. A Burges., D. M. Moore, S. M. Walters \& D. A. WebB (eds.). Flora Europaea, vol. 5 Alismataceae to Orchidaceae (Monocotyledones), pp. 290-323. Cambridge University Press, Cambridge.

Clymo R. S. 1962. An experimental approach to part of the calcicole problem. Journal of Ecology 50: 707-731.

CRINS W. J. 1985. The taxonomy of Carex section Ceratocystis in North America and Northen Eurasia. Ph. D. Thesis, Department of Botany, University of Toronto, Canada. 
Crins W. J. 2002. Carex sect. Ceratocystis Dumort. In: P. W. Ball, A. A. RezniceK \& D. F. Murray (eds.). Flora of North America north of Mexico, vol. 23, pp. 523-537. Oxford University Press, New York.

CRINS W. J. \& BAll P. W. 1987. Variation in Carex hostiana (Cyperaceae). Rhodora 89: 247-259.

Crins W. J. \& Ball P. W. 1988. Sectional limits and phylogenetic consideration in Carex section Ceratocystis (Cyperaceae). Brittonia 40: 38-47.

CRINS W. J. \& BALL P. W. 1989a. Taxonomy of the Carex flava complex (Cyperaceae) in North America and northern Eurasia. I. Numerical taxonomy and character analysis. Can. J. Bot. 67: 1032-1047.

Crins W. J. \& Ball P. W. 1989b. Taxonomy of the Carex flava complex (Cyperaceae) in North America and northern Eurasia. II. Taxonomic treatment. Can. J. Bot. 67: 1048-1065.

ĆWIKLIŃSKi E. 1986. Rejon obfitego występowania Carex aristata $\mathrm{R}$. Br. w województwie szczecińskim i nowy zespół Caricetum aristati. Fragm. Flor. Geobot. 29(34): 393-400.

Davies E. W. 1953a. Notes on Carex flava and its alliens. I. A sedge new to the British Isles. Watsonia 3: 66-69.

Davies E. W. 1953b. Notes on Carex flava and its alliens. II. Carex lepidocarpa in the British Isles. Watsonia: 3:70-73.

Davies E. W. 1953c. Notes on Carex flava and its alliens. III. The taxonomy and morphology of the British representatives. Watsonia 3: 74-79.

Davies E. W. 1955. The cytogenetics of Carex flava and its allies. Watsonia 3: 129-137.

Davies E. W. 1956. The ecology and distribution of Carex flava and its allies in the British Isles. Botaniska Notiser 109: 51-74.

Derieg N. J., Sangaumphai A. \& Bruederle L. P. 2008. Genetic diversity and endemism in North American Carex section Ceratocystis (Cyperaceae). Am. J. Bot. 95(10): 1287-1296.

Derieg N. J., Weil S. J., Reznicek A. A. \& Bruederle L. P. 2013. Carex viridistellata sp. nov. (Cyperaceae), a new cryptic species from prairie fens of the Eastern United States. Syst. Bot. 38(1): 82-91.

Du Rietz G. E. 1930. The fundamental units of biological taxonomy. Svensk Botanisk Tidskrift 24: 333-428.

Egorova T. V. 1999. The sedges (Carex L.) of Russia and adjacent states (within the limits of the former USSR). 772 pp. Missouri Botanical Garden Press, Saint-Louis.

Fagerström L. 1967. Studien an der Carex-section Extensae Fr. Acta Societas pro Fauna et Flora Fennica 79(3): 1-14.

Frodin D. G. 2004. History and concepts of big plant genera. Taxon 53: 753-776.

Genrke B. 2011. Synopsis of Carex (Cyperaceae) from sub-Saharan Africa and Madagascar. Bot J Linn Soc 166: 51-99.

Goetghebeur P. 1998. Monocotyledons. In: K. Kubitzki, H. Huber, P. J. Rusall, P. S. Stevens \& T. Stützel (eds.). The families and genera of vascular plants, vol. 4. pp. 141-190. Springer, Berlin.

Govaerts R. \& Simpson D. A. 2007. World Checklist of Cyperaceae. Sedges: 1-765. The Board of Trustees of the Royal Botanic Gardens, Kew.
Govaerts R., Koopman J., Simpson D., Goetghebeur P., WiLSON K., EgOROVA T. \& BRUHL J. 2010. World checklist of Cyperaceae. Kew: The Board of Trustees of the Royal Botanic Gardens. Available at http://apps.kew. org/wcsp/monocots/ (accessed 25 May 2011).

Grant V. 1981. Plant speciation. 563 pp. Columbia University Press, New York.

Grulich V. \& ŘepKa R. 2002. Carex L. - ostřice. In: K. KubÁt, L. Hrouda, J. Jun. Chrtek, Z. Kaplan, J. Kirschner, \& ŠTĚPÁNEK J. (eds). Klíč ke květeně České republiky, pp. 801-820. Academia, Praha.

Halkka L., Toivonen H., SaArio S. \& Pykälä J. 1992. Chromosome counts in the Carex flava complex (Cyperaceae) in Finland. Nordic J. Bot. 12: 651-655.

Havlícková J. 1982. Carex flava-complex in the Czech lands. I. Analysis of the variability of morphological characters. Preslia 54: 201-222.

Hedrén M. 1990. Problems in Carex jemtlandica and C. bergrothii (Cyperaceae) in Sweden. Sommerfeltia 11: 109-115.

HEDRÉN M. 1994. Morfologisk variation hos näbbstarr och jämtstarr (Carex lepidocarpa s. 1.) i Sverige. Svensk Botanisk Tidskrift 88: 129-141.

Hedrén M. 1996. Genetic differentiation among Finnish, Norwegian and Swedish Carex lepidocarpa s.lat. (Cyperaceae). Symbolae Botanicae Upssalienses 31: 105-113.

Hedrén M. 1998. Status of Carex bergrothii (Cyperaceae) on Gotland SE Sweden. Nordic J. Bot. 18: 41-49.

HEDRÉN M. 2002. Patterns of allozyme and morphological differentiation in the Carex flava complex (Cyperaceae) in Fennoscandia. Nordic J. Bot. 22: 257-301.

Hedrén M. 2004. Species delimitation and the partitioning of genetic diversity - an example from the Carex flava complex (Cyperaceae). Biodiversity and Conservation 13: 297-316.

Hedrén M. \& Prentice H. C. 1996. Allozyme variation and racial differentiation in Swedish Carex lepidocarpa s.l. (Cyperaceae). Biol J Linn Soc 59: 179-200.

Heide O. M. 1997. Environmental control of flowering in some northen Carex species. Ann. Bot. 79: 319-327.

Heide O. M. 2004. Environmental control of flowering and sex expression in Carex flava. Physiologia Plantarum 121: 691-698.

Hendrichs M., Oberwinkler F., Begerow D. \& Bauer R. 2004. Carex, subgenus Carex (Cyperaceae) - A phylogenetic approach using ITS sequences. Plant Syst Evol 246: 89-107.

Hipp A. L., Rothrock P. E. \& Roalson E. H. 2009. The evolution of chromosome arrangements in Carex (Cyperaceae). Bot Rev 75: 96-109.

Holub J. 1999. Carex viridula Michx. subsp. pseudosacandinavica Holub. In: Red data book of threatened plants and animals of the Czech Republic and Slovak Republic 5. Higher plants. 286 pp. Př́roda, Bratislava.

Holub J., ProcházKa F. \& Čeřovský J. 1979. List of extinct, endemic and threatened of vascular plants of the flora of the Czech Socialist Republic (first draft)]. Preslia 51: 213-237.

JANYSZEK M. \& JAGODZIŃSKi A. M. 2009. Variability of perigynium morphology of Central European members 
of Carex sect. Phaestoglochin (Cyperaceae) from variable plant communities. Plant Syst Evol 278: 87-99.

JASIEwicz A. 1965. Rośliny naczyniowe Bieszczadów Zachodnich. Monogr. Bot. 20: 3-337.

Jermy J., Simpson D. A., Foley M. \& Porter M. 2007. Sedges of the British Isles. 554 pp. Botanical Society of the British Isles, London.

Jiménez-Mejías P. \& Luceño M. 2009. Carex castroviejoi Luceño \& Jim.-Mejías (Cyperaceae), a new species from North Greek mountains. Acta Botanica Malacitana 34: 231-233.

Jiménez-Mejías P., Martín-Bravo S. \& Luceño M. 2012a. Systematics and taxonomy of Carex sect. Ceratocystis (Cyperaceae) in Europe: a molecular and cytogenetic approach. Syst. Bot. 37(2): 382-398.

Jiménez-Mejías P., Martin-Bravo S., Rat M., AnačKov G. \& LuCEÑO M. 2012b. New records of Southeast European Carex L. (Cyperaceae). Biologia Serbica 34 (1-2): 100-102.

KAŹMIERSKi A. 2004. Refleksje nad koncepcjami gatunku. In: W. Niedbata \& K. Łastowski (eds.). Gatunek w systematyce. pp. 9-18. Polskie Towarzystwo Taksonomiczne i Biologica Silesiae, Wrocław-Poznań.

KIFFE K. 1998. Aktuelle Vorkommen von Hybriden innerhalb der Carex flava Gruppe (Cyperaceae) in Westfalen. Natur und Heimat 58(1): 1-8.

KIFFE K. 2001. Die Hybriden zwischen Carex hostiana und den Arten der Carex flava-Gruppe in NordrheinWestfalen. Floristische Rundbriefe 35(1/2): 61-71.

KLIMко M. 1981. Zmienność populacji i stanowisko systematyczne Carex nigra (L.) Reichard w Polsce. PTPN, Prace Kom. Biol. 57: 5-72.

Kondracki J. 2002. Geografia regionalna Polski. 441 pp. Wyd. Nauk. PWN, Warszawa.

Koopman J. 2010. Carex-hybriden in Nederland. Gorteria 34: $159-169$.

Koopman J. 2011. Carex Europaea. The genus Carex L. (Cyperaceae) in Europe, 1. Accepted names, hybrids, synonyms, distribution, chromosome numbers. 726 pp. Margraf Publishers, Weikersheim.

Krawiecowa A. \& KuczyńsKa I. 1959. Carex aristata R. Br. Fragm. Flor. Geobot. 5(3): 389-396.

KuKKONEN I. 1984. New infraspecific taxa and nomenclatural combinations in Carex (Cyperaceae) in the Flora Iranica area. Ann. Bot. Fenn. 21: 383-389.

KÜKenthal G. 1909. Cyperaceae-Caricoideae. In: A. EnGLeR (ed). Das Pflanzenreich. vol. 4 (21), pp. 1-824. Wilhelm Engelmann, Leipzig.

LATOWSKI K. 2004. O zróżnicowaniu wewnątrzgatunkowym u magnoliofitów. In: W. Niedbala \& K. ŁastowsKi (eds.). Gatunek w systematyce. 76-90 pp. Polskie Towarzystwo Taksonomiczne i Biologica Silesiae, Wrocław-Poznań.

LeBlond R. J., Weakley A. S., Reznicek A. A. \& Crins W. J. 1994. Carex lutea (Cyperaceae), a rare new Coastal Plain endemic from North Carolina. Sida 16: 152-161.

Lembicz M., Bogdanowicz A. \& Żukowski W. 2006. Production and structure of unisexual and bisexual inflorescences in populations of Carex secalina (Cyperaceae). Polish Bot. Studies 22: 343-346.
Lembicz M., Rogowski A., Jarmołowski A., Bogdanowicz A. \& ŻUKowsKi W. 2010. Historical versus present populations of the sedge Carex repens: a comparision on the basis of molecular date. Phytotaxa 3: 19-26.

López A. \& Morrone O. 2012. Phylogenetic studies in Axonopus (Poaceae, Panicoideae, Paniceae) and related genera: morphology and molecular (nuclear and plastid) combined analyses. Syst. Bot. 37(3): 671-676.

LuCeño M. 1994. Monografias del genero Carex en la Peninsula Iberica e Islas Baleares. Ruizia 14: 1-139.

LuCEÑo M. 1999. Dos combinaciones nuevas en Cyperaceae. Anales del Jardín Botánico de Madrid 57(1): 176.

Luceño M. \& Castroviejo S. 1993. Cytotaxonomic studies in the sections Spirostachyae (Drejer) Bailey and Ceratocystis Dumort. of the genus Carex L. (Cyperaceae) with special reference to Iberian and North African taxa. Bot. J. Linn. Soc. 112: 335-350.

Luceño M. \& Jiménez-Mejías P. 2007. Sect. Ceratocystis Dumort. In: S. Castroviejo, M. Luceño \& A. Galán (eds.). Flora Iberica. Plantas vasculares de la Península Ibérica e Islas Baleares. 18: 191-203. CyperaceaePontederiaceae. Real Jardín Botánico, Csic, Madrit.

MAYr E. 1957. Species concepts and definitions. In: E. MAYR (ed.). The species problem. American Association for Advancement of Science Publication. 50: 1-22, Washington.

van der Meijden R. \& Holverda W. J. 2006. Revisie van het NHN-hermariummateriaal van Carex lepidocarpa Tausch (Schubzegge) en Carex flava L. (Gele zegge) in Nederland. Gorteria 31(6): 129-136.

Mirek Z., Musią L. \& WójCicki J. J. 1997. Polish Herbaria. Polish Bot. Stud. Guidebook Series 8: 1-116.

Mirek Z., Piękoś-Mirkowa H., Zając A. \& Zając M. 2002. Flowering plants and pteridophytes of Poland. A checklist. In: Z. MireK (ed.). Biodiversity of Poland, vol. 1, pp. 442. W. Szafer Institute of Botany, Polish Academy of Sciences, Kraków.

Mitka J. 2004. Taksonomia lineuszowska w dobie biologii molekularnej. Fragm. Flor. Geobot. Polonica, Suppl. 6: 9-31.

Molina A., Acedo C. \& Llamas F. 2012. A comparative study of the inflorescence in the genus Carex (Cyperaceae). Syst. Bot. 37(2): 365-381.

ODRZYKOSKI I. J. 2004. Gatunki kryptyczne u mszaków. In: W. Niedbala \& K. Łastowski (eds.). Gatunek w systematyce. pp. 58-75. Polskie Towarzystwo Taksonomiczne i Biologica Silesiae, Wrocław-Poznań.

Palmgren A. 1946. Carex oederi Retz. × oedocarpa (Ands.), C. oederi Retz. *pulchella Lönnr., C. viridula Michx. Memoranda Societatis pro Fauna et Flora Fennica 22: 119-128.

Palmgren A. 1959. Carex-gruppen Fulvellae Fr. i Fennoskandien I. Flora Fennica 2: 1-165.

Patzke E. \& Podlech D. 1960. Die Verbreitung der Carex flava-gruppe im nördlichen Rheingebiet. Decheniana 113: 265-273.

Pawlikowski P. 2010. Carex disperma Dewey versus Carex loliacea L. (Cyperaceae): distribution dynamics and conservation status in Poland. Acta Soc. Bot. Pol. 79(4): 277-283. 
PYкÄLÄ J. 1994. The ecology and distribution of Carex lepidocarpa subsp. lepidocarpa in Finland. Ann. Bot. Fenn. 31: 261-274.

PykÄlä J. \& Toivonen H. 1994. Taxonomy of the Carex flava complex (Cyperaceae) in Finland. Nordic J. Bot. 14: 173-191.

Raciborski M. 1919. Cyperales. In: M. Raciborski \& W. Szafer (eds.). Flora Polska. Rośliny naczyniowe Polski i ziem ościennych. 1. Paprotniki, iglaste i jednoliścienne, pp. 155-320. Akademia Umiejętności, Kraków.

Reznicek A. A. 1990. Evolution in sedges (Carex, Cyperaceae). Can. J. Bot. 68: 1409-1432.

Rich M. D. B. 1998. Carex. In: T. C. G. Rich \& A. C. Jermy (eds.). Plant Crib. 400 pp. Botanical Society of the British Isles, London.

RIESEBERG L. H. 1995. The role of hybridization in evolution: old wine in a new skins. Am. J. Bot. 82: 944-953.

Rieseberg L. H. 1997. Hybrid origins of plant species. Annual Reviews Ecology and Systematics 28: 359-389.

RoAlson E. H. 2008. A synopsis of chromosome number variation in the Cyperaceae. Botanical Review 74: 209-393.

Roalson E. H., Columbus T. J. \& Friar E. A. 2001. Phylogenetic relationships in Cariceae (Cyperaceae) based on ITS (nrDNA) and trnT-L-F (cpDNA) region sequences: assessment of subgeneric and sectional relationships in Carex with emphasis on section Acrocystis. Syst. Bot. 26: 318-341.

Rotreklová O., Bureš P., Řepka R., Grulich V., Šmardal P., Hralova I., Zedek F. \& Koutecky T. 2011. Chromosome numbers of Carex. Preslia 83: 25-58.

SAlo V., PykÄLÄ J. \& Toivonen H. 1994. Achene epidermis in the Carex flava complex (Cyperaceae) studied by scanning electron microscopy. Ann. Bot. Fenn. 31: 45-52.

Schmid B. 1981. Die Verbreitung der Artengruppe Carex flava L. s.1. in der Schweiz. Botanica Helvetica 91: 3-8.

Schmid B. 1982. Karyology and hybridization in the Carex flava complex in Switzerland. Feddes Repertorium 93: 23-59.

Schmid B. 1983. Notes of nomenclature and taxonomy of the Carex flava group in Europe. Watsonia 14: 309-319.

Schmid B. 1984a. Life histories in clonal plants of the Carex flava group. J. Ecol. 72: 93-114.

Schmid B. 1984b. Niche width and variation within and between populations in colonizing species (Carex flava group). Oecologia 63: 1-5.

Schmid B. 1986a. Patterns of variation and population structure in the Carex flava group. Symbolae Botanicae Uppsaliensis 27: 113-126.

Schmid B. 1986b. Colonizing plants with persistent seeds and persistent seedlings (Carex flava group). Botanica Helvetica 96: 19-26.

Sell P. 1996. Carex section Ceratocystis Dumort. In: P. Sell \& G. Murrell (eds.). Flora of Great Britain and Ireland, vol. 5. pp. 109-111. Cambridge University Press, Cambridge.

SkÅrman J. A. O. 1940. Carex oederi Ehrh. *pulchella Lönnr. Svensk Botanisk Tidskrift 34: 409-419.
Sneath P. H. A. \& Sokal R. R. 1973. Numerical taxonomy. The principles and practice of numerical classification. 573 pp. W. H. Freeman and Co., San Francisco.

Sokal R. R. \& Crovello T. J. 1970. The biological species concept: A critical evaluation. American Naturalist 104: 127-153.

Sotek Z. 2006. The distribution of Carex buxbaumii Wahlenb. in Poland. Acta Soc. Bot. Pol. 75(4): 293-296.

Soтек Z. 2008. The distribution of Carex hartmanii Cajander in Poland. Acta Soc. Bot. Pol. 77(4): 323-326.

Stace C. A. 1989. Plant taxonomy and biosystematics. 265 pp. Edward Arnold, London.

Stace C. A. 2005. New flora of the British Isles. 1232 pp. Cambridge University Press, Cambridge.

Statsoft InC. 2007. Statistica (data analysis software system), v. 8.0. www.statsoft.com.

STOEVA M. P. \& ŠTePÁNKOVÁ J. 1990. Variation patterns within the Carex flava agg. in Bulgaria and Czechoslovakia. Preslia 62: 1-24.

ŠtepánkovÁ J. 2008. Carex derelicta, a new species from the Krkonoše Mountains (Czech Republic). Preslia 80: 389-397.

SzCZEPANIK-JANYSZEK M. 2001. Studia systematyczno-geograficzne nad gatunkami z rodzaju Carex L., z sekcji Muehlenbergianae (L. H. Bailey) Kük. w Polsce. Rozprawy Naukowe 311, pp. 71. Roczniki Akademii Rolniczej w Poznaniu, Poznań.

SZCZEPANIK-JANYSZEK M. \& WoźNICA M. 2001. Taksonomia i rozmieszczenie gatunków z rodzaju Carex L., z sekcji Vulpinae (Carey) Christ. w województwie wielkopolskim. Roczniki Akademii Rolniczej w Poznaniu 334, Seria Botanica 4: 175-196.

SzCZEPANIK-JANYSZEK M. 2003. Taksonomia polskich gatunków turzyc - Carex L., z sekcji Paniculatae (Carey) Christ. Roczniki Akademii Rolniczej w Poznaniu 354, Seria Botanica 6: 163-176.

Szeląg Z. 2001. Carex pallens (Cyperaceae), a species new to Poland. Polish Botanical Journal 46(1): 75-77.

Szeląg Z. 2002. Carex curvata (Cyperaceae) in Poland. Polish Botanical Journal 47(1): 37-39.

ter BraAk C. J. F. \& Šmilauer P. 2002. CANOCO Reference Manual and User's Guide to Canoco for Windows, Software for Canonical Community Ordination (version 4.5). Microcomputer Power, Ithaca, NY, USA.

Towpasz K. 1969. Rozmieszczenie Carex pediformis C. A. Mey w Polsce i krajach ościennych. Fragm. Flor. Geobot. 15 (1): 9-12.

Turesson G. 1922. The genotypical response of the plant species to the habitat. Hereditas 3: 211-350.

UrbaniaK L. 1992. A comparison between Carex arenaria L. and Carex ligerica Gay - sedges from the Arenariae group based on leaf characteristics. Acta Soc. Bot. Pol. 61(2): 265-271.

URBANIAK L. 1998. Morphometric differentiation of Carex ligerica Gay in Poland. Acta Soc. Bot. Pol. 67(3-4): 263-268.

Urbaniak L., Maik I. \& UrbaniaK D. 2000. Differentiation between Carex arenaria populations at the eastern range margin based on female and male glumes variation. Acta Soc. Bot. Pol. 69(1): 65-74. 
VAN VALEN L. 1976. Ecological species, multispecies, and oaks. Taxon 25: 233-239.

Vonk D. H. 1979. Biosystematic studies of the Carex flava complex I. Flowering. Acta Botanica Neerlandica 28: $1-20$

Wallace E. C., Benoit P. M., Chater A. O, Jermy A. C. \& Stace C. A. 1975. Carex L. In: C. A. Stace (eds.). Hybridization and the Flora of the British Isles. pp. 513-540. Academic Press, London.

Waterway M. J., Hoshino T. \& Masaki T. 2009. Phylogeny, species richness, and ecological specialization in Cyperaceae Tribe Cariceae. Botanical Review 75:138-159.

WIĘCŁAW H. 2011. Morphological variability of the Carex oederi s.l. inflorescence. Biodiv. Res. Conserv. 21: 13-18.

WięCŁaW H. \& Ciaciura M. 2005. Stanowiska Carex atherodes (Cyperaceae) na Pojezierzu Zachodniopomorskiim. Fragm. Flor. Geobot. Polonica 12(2): 249-257.

WiĘCŁAW H. \& KoOpman J. 2013. Numerical analysis of morphology of natural hybrids between Carex hostiana DC. and the members of Carex flava agg. (Cyperaceae). Nordic J. Bot. 31(4): 464-472.

WięCŁAW H \& PodLAsińSKi M. 2013. Morphological differences between natural populations of Carex viridula (Cyperaceae): effects of soil conditions. Ann. Bot. Fenn. 50 (1-2): 13-22.
WięCŁaW H. \& Wilhelm M. 2014. Natural hybridization within the Carex flava complex (Ceratocystis, Cyperaceae) in Poland: morphometric studies. Ann. Bot. Fenn. 51: 129-147.

WiINSTEND K. 1947. Bildrag til polymorfien hos den tidligere som Carex oederi Retz. kente art. Botanisk Tidskrift 48: 192-206.

Wissemann V. 2005. Evolution by hybridization. The influence of reticulate evolution on biosymmetrical patterns and processes in plants. Theory in Biosciences 123(3): 223-233.

Yen A. C. \& Olmstead R. G. 2000. Molecular systematics of Cyperaceae tribe Cariceae based on two chloroplast DNA regions: $n d h F$ and $t r n L$ intron-intergenic spacer. Syst. Bot. 25: 479-494.

ZAJĄC A. 1968. Carex serotina Mér. subsp. pulchella (Lönnr.) v. Ooststr. w Polsce. Fragm. Flor. Geobot. 14(2): 205-211.

Żunowski W. \& Lembicz M. 2000. Carex pseudobrizoides (Cyperaceae) in Poland: patterns of isozymatic phenotypes. Fragm. Flor. Geobot. 45(1): 265-271.

Żukowski W., Lembicz M., Olejniczak P., Bogdanowicz A., Chmiel J. \& Rogowski A. 2005. Carex secalina (Cyperaceae), a species critically endangered in Europe: from propagule germination to propagule production. Acta Soc. Bot. Pol. 74(2): 141-147. 
Appendix 1. Geographic location of collection sites of sedges of the Carex flava group

\begin{tabular}{|c|c|c|c|}
\hline No. & Location of collection sites & No. of specimens & Taxon \\
\hline \multicolumn{4}{|c|}{ Koszalin Coast District (Pobrzeże Koszalińskie) } \\
\hline 1 & $\begin{array}{l}\text { Słowińskie Coast (Wybrzeże Słowińskie), Kluki, meadow S of village } \\
54^{\circ} 40^{\prime} 02.0^{\prime \prime} \mathrm{N}, 17^{\circ} 20^{\prime} 18.4^{\prime \prime} \mathrm{E}\end{array}$ & 24 & $\mathrm{D}$ \\
\hline 2 & $\begin{array}{l}\text { Słowińskie Coast, Retowo, pasture S of Lake Gardno } \\
54^{\circ} 37^{\prime} 29.1^{\prime \prime N}, 17^{\circ} 06^{\prime} 37.3^{\prime \prime E}\end{array}$ & 21 & $\mathrm{D}$ \\
\hline 3 & $\begin{array}{l}\text { Słowińskie Coast, Gardna Wielka, meadow near E edge of Lake Gardno } \\
54^{\circ} 39^{\prime} 07.5^{\prime \prime} \mathrm{N}, 17^{\circ} 10^{\prime} 17.7^{\prime \prime} \mathrm{E}\end{array}$ & 22 & $\mathrm{D}$ \\
\hline 4 & $\begin{array}{l}\text { Słowińskie Coast, Łeba, depression between dunes, } \mathrm{N} \text { of Lake Łebsko } \\
54^{\circ} 44^{\prime} 56.4^{\prime \prime} \mathrm{N}, 17^{\circ} 25^{\prime} 16.9^{\prime \prime} \mathrm{E}\end{array}$ & 30 & $\mathrm{~V}$ \\
\hline 5 & $\begin{array}{l}\text { Słowińskie Coast, Łeba, depression between dunes, } \mathrm{N} \text { of Lake Łebsko } \\
54^{\circ} 44^{\prime} 43.4^{\prime \prime} \mathrm{N}, 17^{\circ} 24^{\prime} 30.9^{\prime \prime} \mathrm{E}\end{array}$ & 15 & $\mathrm{~V}$ \\
\hline 6 & $\begin{array}{l}\text { Białogard Plain (Równina Białogardzka), Bagicz, roadside depression, } \mathrm{N} \text { of road } \\
\text { Sianożęty-Bagicz } \\
54^{\circ} 11^{\prime} 55.1^{\prime \prime} \mathrm{N}, 15^{\circ} 41^{\prime} 32.4^{\prime \prime} \mathrm{E}\end{array}$ & 25 & $\mathrm{D}$ \\
\hline 7 & $\begin{array}{l}\text { Białogard Plain, Sianożęty, damp depression on cliff, about } 150 \mathrm{~m} \mathrm{~W} \text { of village } \\
54^{\circ} 12^{\prime} 20.70^{\prime \prime} \mathrm{N}, 15^{\circ} 42^{\prime} 31.44^{\prime \prime} \mathrm{E}\end{array}$ & 25 & $\mathrm{~V}$ \\
\hline \multicolumn{4}{|c|}{ Gdańsk Coast District (Pobrzeże Gdańskie) } \\
\hline 8 & $\begin{array}{l}\text { Kashubian Coast District (Pobrzeże Kaszubskie), Osłonino near Puck, low-sedge fen } \\
\text { in nature reserve "Beka" } \\
54^{\circ} 39^{\prime} 21.84 " \mathrm{~N}, 18^{\circ} 27^{\prime} 38.70^{\prime E} \mathrm{E}\end{array}$ & 38 & L,V,Sch \\
\hline 9 & $\begin{array}{l}\text { Białogóra, sandy depression } \\
54^{\circ} 49^{\prime} 25.56^{\prime \prime} \mathrm{N}, 17^{\circ} 58^{\prime} 31.02^{\prime \prime} \mathrm{E}\end{array}$ & 28 & $\mathrm{~V}$ \\
\hline 10 & $\begin{array}{l}\text { Sławoszynko, forest and roadside near nature reserve "Bielawa", E of village } \\
54^{\circ} 48^{\prime} 00.12^{\prime \prime N}, 18^{\circ} 13^{\prime} 37.26^{\prime \prime} \mathrm{E}\end{array}$ & 15 & $\mathrm{~V}$ \\
\hline \multicolumn{4}{|c|}{ Szczecin Coast District (Pobrzeże Szczecińskie) } \\
\hline 11 & $\begin{array}{l}\text { Trzebiatów Coast (Wybrzeże Trzebiatowskie), Łowno near Międzywodzie, salt- } \\
\text { marsh } \\
53^{\circ} 59^{\prime} 49.0^{\prime \prime} \mathrm{N}, 14^{\circ} 41^{\prime} 09.6^{\prime \prime} \mathrm{E}\end{array}$ & 2 & $\mathrm{~V}$ \\
\hline 12 & $\begin{array}{l}\text { Pyrzyce-Stargard Plain (Równina Pyrzycko-Stargardzka), Grędziec, meadow near } \\
\text { emergent vegetation of E edge of Lake Miedwie } \\
53^{\circ} 13^{\prime} 10.50^{\prime \prime N}, 14^{\circ} 55^{\prime} 05.88^{\prime \prime} \mathrm{E}\end{array}$ & 20 & $\mathrm{~V}$ \\
\hline 13 & $\begin{array}{l}\text { Pyrzyce-Stargard Plain, Lubiatowo, N edge of Lake Torfowe } \\
53^{\circ} 09^{\prime} 42.12^{\prime \prime N}, 15^{\circ} 01^{\prime} 59.01^{\prime \prime E}\end{array}$ & 28 & $\mathrm{~L}, \mathrm{~V}$ \\
\hline 14 & $\begin{array}{l}\text { Pyrzyce-Stargard Plain, Lubiatowo, ditch and chalk pit near pasture } \\
53^{\circ} 10^{\prime} 13.56^{\prime \prime} \mathrm{N}, 15^{\circ} 02^{\prime} 36.72^{\prime \mathrm{E}}\end{array}$ & 4 & V \\
\hline 15 & $\begin{array}{l}\text { Pyrzyce-Stargard Plain, Będgoszcz, waterlogged meadow near N edge of Lake } \\
\text { Będgoszcz } \\
53^{\circ} 14^{\prime} 54.00^{\prime \prime} \mathrm{N}, 14^{\circ} 48^{\prime} 22.62^{\prime \prime} \mathrm{E}\end{array}$ & 32 & $\mathrm{~L}$ \\
\hline 16 & $\begin{array}{l}\text { Pyrzyce-Stargard Plain, Zaborsko, meadow, SE edge of Lake Zaborsko } \\
53^{\circ} 10^{\prime} 28.7^{\prime \prime N}, 15^{\circ} 00^{\prime} 20.8^{\prime \prime} \mathrm{E}\end{array}$ & 29 & $\mathrm{~L}, \mathrm{~V}, \mathrm{Sch}$ \\
\hline 17 & $\begin{array}{l}\text { Police Plain (Równina Wkrzańska = Równina Policka), Stolec, meadow and } \\
\text { depression near waterhole, E of village } \\
53^{\circ} 33^{\prime} 05.0^{\prime \prime} \mathrm{N}, 14^{\circ} 20^{\prime} 52.6^{\prime \prime} \mathrm{E}\end{array}$ & 28 & V \\
\hline 18 & $\begin{array}{l}\text { Police Plain, Zalesie, meadow, S of Forest District headquarters near Lake Świdwie } \\
53^{\circ} 34^{\prime} 42.24^{\prime \prime} \mathrm{N}, 14^{\circ} 21^{\prime} 25.08^{\prime \prime} \mathrm{E}\end{array}$ & 20 & $\mathrm{~F}$ \\
\hline 19 & $\begin{array}{l}\text { Goleniów Plain (Równina Goleniowska), Modrzewie, fen } \\
53^{\circ} 34^{\prime} 45.96^{\prime \prime} \mathrm{N}, 14^{\circ} 42^{\prime} 53.52^{\prime \prime} \mathrm{E}\end{array}$ & 36 & $\mathrm{~F}, \mathrm{~L}, \mathrm{R}, \mathrm{V}$ \\
\hline 20 & $\begin{array}{l}\text { Goleniów Plain, Krępsko, fen } \\
53^{\circ} 35^{\prime} 31.08^{\prime \prime N}, 14^{\circ} 43^{\prime} 12.06 " \mathrm{E}\end{array}$ & 10 & $\mathrm{~F}$ \\
\hline 21 & $\begin{array}{l}\text { Goleniów Plain, Ogorzele, forest meadow, E of village } \\
53^{\circ} 42^{\prime} 14.6^{\prime} \mathrm{N}, 15^{\circ} 01^{\prime} 17.9^{\prime} \mathrm{E}\end{array}$ & 30 & $\mathrm{~F}$ \\
\hline 22 & $\begin{array}{l}\text { Goleniów Plain, Budzeń near Stepnica, meadow } \\
53^{\circ} 36^{\prime} 54.42^{\prime \prime N}, 14^{\circ} 40^{\prime} 51.72^{\prime E}\end{array}$ & 14 & $\mathrm{~F}$ \\
\hline \multicolumn{4}{|c|}{ West Pomeranian Lakeland (Pojezierze Zachodniopomorskie) } \\
\hline 23 & $\begin{array}{l}\text { Choszczno Lakeland (Pojezierze Choszczeńskie), Kiełpino, forest meadow } \\
53^{\circ} 13^{\prime} 22.6^{\prime \prime} \mathrm{N}, 15^{\circ} 40^{\prime} 45.9^{\prime \prime} \mathrm{E}\end{array}$ & 82 & $\mathrm{D}, \mathrm{F}, \mathrm{A}, \mathrm{L}$ \\
\hline 24 & $\begin{array}{l}\text { Choszczno Lakeland, Kiełpino, alder carr } \\
53^{\circ} 13^{\prime} 22.8^{\prime \prime} \mathrm{N}, 15^{\circ} 40^{\prime} 45.4^{\prime \prime} \mathrm{E}\end{array}$ & 10 & $\mathrm{~F}$ \\
\hline
\end{tabular}




\begin{tabular}{|c|c|}
\hline No. & Location of collection sites \\
\hline 25 & $\begin{array}{l}\text { Myślibórz Lakeland (Pojezierze Myśliborskie) Sitno, calcareous fen near Lake } \\
\text { Tchórzyno } \\
53^{\circ} 00^{\prime} 40.0^{\prime \prime} \mathrm{N}, 14^{\circ} 51^{\prime} 08.9^{\prime \prime} \mathrm{E}\end{array}$ \\
\hline 26 & $\begin{array}{l}\text { Myślibórz Lakeland, calcareous meadow near Lake Chłop } \\
52^{\circ} 59^{\prime} 23.52^{\prime \prime} \mathrm{N}, 14^{\circ} 54^{\prime} 00.24^{\prime \prime} \mathrm{E}\end{array}$ \\
\hline 27 & $\begin{array}{l}\text { Ińsko Lakeland (Pojezierze Ińskie), Ińsko, N edge of Lake Długie } \\
53^{\circ} 26^{\prime} 31.7^{\prime} \mathrm{N}, 15^{\circ} 35^{\prime} 37.3^{\prime} \mathrm{E}\end{array}$ \\
\hline 28 & $\begin{array}{l}\text { Ińsko Lakeland, Studnica, E edge of Lake Kiełpino Duże } \\
53^{\circ} 26^{\prime} 29^{\prime \prime} \mathrm{N}, 15^{\circ} 37^{\prime} 10^{\prime \prime} \mathrm{E}\end{array}$ \\
\hline 29 & $\begin{array}{l}\text { Drawsko Lakeland (Pojezierze Drawskie), Kluczewo, meadow near W edge of Lake } \\
\text { Prosino } \\
53^{\circ} 38^{\prime} 44.52^{\prime \prime} \mathrm{N}, 16^{\circ} 11^{\prime} 32.82^{\prime \prime} \mathrm{E}\end{array}$ \\
\hline 30 & $\begin{array}{l}\text { Drawsko Lakeland, Kluczewo, alder carr near W edge of Lake Prosino } \\
53^{\circ} 38^{\prime} 49.86^{\prime \prime}, 16^{\circ} 11^{\prime} 35.52^{\prime \prime E}\end{array}$ \\
\hline
\end{tabular}

\section{South Pomeranian Lakeland (Pojezierze Poludniowopomorskie)}

31 Tuchola Forest (Bory Tucholskie), Lake Wdzydze, meadow, Sidły Island

F,L $54^{\circ} 59^{\prime} 12^{\prime \prime} \mathrm{N}, 17^{\circ} 53^{\prime} 36^{\prime \prime} \mathrm{E}$

32 Tuchola Forest, Schodno, meadow near SW edge of Lake Bielawy $54^{\circ} 02^{\prime} 42^{\prime \prime} \mathrm{N}, 17^{\circ} 49^{\prime} 50^{\prime \prime} \mathrm{E}$

33 Tuchola Forest, Schodno, poor fen near SW edge of Lake Bielawy $54^{\circ} 02^{\prime} 38^{\prime \prime} \mathrm{N}, 17^{\circ} 49^{\prime} 17^{\prime \prime} \mathrm{E}$

34 Tuchola Forest, S of road Wdzydze Kiszewskie-Gołuń, ecological area "Kiszewskie Bagno" near N edge of Lake Gołuń, poor fen $54^{\circ} 00^{\prime} 28^{\prime \prime} \mathrm{N}, 17^{\circ} 57^{\prime} 47^{\prime \prime} \mathrm{E}$

35 Tuchola Forest, Zazdrość, meadow, SE of village, near forester's lodge $53^{\circ} 39^{\prime} 26.58^{\prime \prime} \mathrm{N}, 18^{\circ} 14^{\prime} 07.08^{\prime \prime} \mathrm{E}$

36 Tuchola Forest, $\mathrm{N}$ of village Łążek, edge of Lake Piaseczno $53^{\circ} 39^{\prime} 38.94 " \mathrm{~N}, 18^{\circ} 15^{\prime} 35.58^{\prime \prime} \mathrm{E}$

37 Tuchola Forest, Laski, meadows, E of village, near Grzybienica Mała river $53^{\circ} 40^{\prime} 04.92^{\prime \prime} \mathrm{N}, 18^{\circ} 14^{\prime} 06.66^{\prime \prime} \mathrm{E}$

38 Tuchola Forest, Stara Rzeka, meadows, W of village, near Czyściewnica river

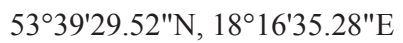

39 Tuchola Forest, Osie, Stary Tartak (old sawmill), alder carr near edge of Lake Czerno $53^{\circ} 34^{\prime} 50.76^{\prime \prime} \mathrm{N}, 18^{\circ} 20^{\prime} 25.05^{\prime \prime} \mathrm{E}$

40 Tuchola Forest, Wda river valley, meadow, forest edge 23 $53^{\circ} 33^{\prime} 55.38^{\prime \prime} \mathrm{N}, 18^{\circ} 19^{\prime} 25.56^{\prime \prime} \mathrm{E}$

41 Świecie Plateau (Wysoczyzna Świecka), Wałkowiska, fen near E edge of Lake Sierosławek $53^{\circ} 33^{\prime} 37.08^{\prime \prime} \mathrm{N}, 18^{\circ} 19^{\prime} 50.10^{\prime \prime} \mathrm{E}$

\section{Chelmno-Dobrzyń Lakeland (Pojezierze Chelmińsko-Dobrzyńskie)}

42 Lubawa Hump (Garb Lubawski), Dąbrówno, meadow, SE of village 25 $53^{\circ} 24^{\prime} 27.96^{\prime \prime} \mathrm{N}, 20^{\circ} 04^{\prime} 07.44^{\prime \prime} \mathrm{E}$

\section{Masurian Lakeland (Pojezierze Mazurskie)}

43 Region of Great Masurian Lakes (Kraina Wielkich Jezior Mazurskich), Borki, nature

\section{Lithuanian Lakeland (Pojezierze Litewskie)}

44 East Suwałki Lakeland (Pojezierze Wschodniosuwalskie), Kramnik, wetland, N of

village $54^{\circ} 18^{\prime} 38.76^{\prime \prime} \mathrm{N}, 22^{\circ} 45^{\prime} 58.68^{\prime \prime} \mathrm{E}$

45 East Suwałki Lakeland, Potopy near Wiżajny, pasture, NE of village $54^{\circ} 20^{\prime} 45.42^{\prime \prime} \mathrm{N}, 22^{\circ} 58^{\prime} 35.34^{\prime \prime} \mathrm{E}$

46 East Suwałki Lakeland, Berżniki, meadow in village, near Kunisjanka stream $54^{\circ} 04^{\prime} 37.26^{\prime \prime} \mathrm{N}, 23^{\circ} 27^{\prime} 59.46^{\prime \prime} \mathrm{E}$

47 West Suwałki Lakeland (Pojezierze Zachodniosuwalskie), Szczebra, peatland in Rospuda river valley $53^{\circ} 54^{\prime} 59.88^{\prime \prime} \mathrm{N}, 22^{\circ} 54^{\prime} 48.96 " \mathrm{E}$ 


\begin{tabular}{lc}
\hline No. & Location of collection sites \\
\hline & Milicz-Głogów Depression (Obniżenie Milicko-Glogowskie)
\end{tabular}

No. of specimens Taxon

48 Milicz Basin (Kotlina Milicka), Nowe Grodziska, meadow in village,

\section{Przedbórz Upland (Wyżyna Przedborska)}

49 Przedbórz-Małogoszcz Range (Pasmo Przedborsko-Małogoskie), Kajetanów, ditch,

E of village $50^{\circ} 59^{\prime} 58.4^{\prime \prime} \mathrm{N}, 20^{\circ} 01^{\prime} 36.8^{\prime \prime} \mathrm{E}$

50 Przedbórz-Małogoszcz Range, Kajetanów, meadow, E of village $50^{\circ} 59^{\prime} 58.4^{\prime \prime} \mathrm{N}, 20^{\circ} 01^{\prime} 36.8^{\prime \prime} \mathrm{E}$

51 Przedbórz-Małogoszcz Range, Kajetanów, meadow, E of village $50^{\circ} 59^{\prime} 48.1^{\prime \prime} \mathrm{N}, 20^{\circ} 01^{\prime} 49.0^{\prime \prime} \mathrm{E}$

52 Przedbórz-Małogoszcz Range, Stanowiska, moist depression close to tall emergent vegetation $50^{\circ} 58^{\prime} 05.8^{\prime \prime} \mathrm{N}, 19^{\circ} 56^{\prime} 30.8^{\prime \prime} \mathrm{E}$

\section{Woźniki-Wieluń Upland (Wyżyna Woźnicko-Wieluńska)}

53 Wieluń Upland (Wyżyna Wieluńska), Strugi near Kochlew, meadow, S of Florian's Spring (Źródło Floriana) $50^{\circ} 12^{\prime} 07.8^{\prime \prime} \mathrm{N}, 18^{\circ} 47^{\prime} 02.3^{\prime \prime} \mathrm{E}$

54 Wieluń Upland, Bobrowniki, Żabi Staw (pond), edge of water body, W of village $51^{\circ} 06^{\prime} 17.5^{\prime \prime} \mathrm{N}, 18^{\circ} 46^{\prime} 06.2^{\prime \prime} \mathrm{E}$

\section{Nida Basin (Niecka Nidziańska)}

55 Nida Valley (Dolina Nidy), Włochy, meadow, S of village 16 $50^{\circ} 31^{\prime} 27.2^{\prime \prime} \mathrm{N}, 20^{\circ} 33^{\prime} 55.8^{\prime \prime} \mathrm{E}$

56 Nida Valley, Włochy, depression with standing water on meadow, $\mathrm{S}$ of village $50^{\circ} 31^{\prime} 28.8^{\prime \prime} \mathrm{N}, 20^{\circ} 34^{\prime} 30.0^{\prime \prime} \mathrm{E}$

57 Nida Valley, Włochy, anthropogenic depression among meadows, on sandy substrate, $\mathrm{S}$ of village $50^{\circ} 31^{\prime} 28.4^{\prime \prime} \mathrm{N}, 20^{\circ} 34^{\prime} 32.4^{\prime \prime} \mathrm{E}$

\section{Western Sudetes (Sudety Zachodnie)}

58 Jelenia Góra Basin (Kotlina Jeleniogórska), Mysłakowice, roadside ditch, $50^{\circ} 50^{\prime} 25.3^{\prime \prime} \mathrm{N}, 15^{\circ} 466^{\prime} 23.0^{\prime \prime} \mathrm{E}$

59 Rudawy Janowickie Mts, Karpniki, forest roadside ( green tourist trail) $50^{\circ} 51^{\prime} 07.3^{\prime \prime} \mathrm{N}, 15^{\circ} 33^{\prime} 38.8^{\prime \prime} \mathrm{E}$

60 Rudawy Janowickie Mts, Karpniki, forest roadside ( yellow tourist trail)

61 Rudawy Janowickie Mts, Karpniki, forest roadside ( blue tourist trail) $50^{\circ} 50^{\prime} 45.5^{\prime \prime} \mathrm{N}, 15^{\circ} 54^{\prime} 38.5^{\prime \prime} \mathrm{E}$

62 Rudawy Janowickie Mts, Rędziny, Przełęcz Rędzińska (mountain pass), meadow $50^{\circ} 49^{\prime} 59.3^{\prime \prime} \mathrm{N}, 15^{\circ} 56^{\prime} 22.1^{\prime \prime} \mathrm{E}$

63 Karkonosze Mts, Karpacz, forest roadside ( green tourist trail) $50^{\circ} 46^{\prime} 10.0^{\prime \prime} \mathrm{N}, 15^{\circ} 43^{\prime} 36.8^{\prime \prime} \mathrm{E}$

64 Karkonosze Mts, Karpacz, forest roadside ( green tourist trail) $50^{\circ} 46^{\prime} 07.2^{\prime \prime} \mathrm{N}, 15^{\circ} 43^{\prime} 05.4^{\prime \prime} \mathrm{E}$

\section{Eastern Sudetes (Sudety Wschodnie)}

65 Massif of Śnieżnik (Masyw Śnieżnika), Międzygórze, pasture

66 Massif of Śnieżnik, Międzygórze, forest roadside ( yellow tourist trail)

67 Massif of Śnieżnik, Jaworek, meadow 


\begin{tabular}{|c|c|c|c|}
\hline No. & Location of collection sites & No. of specimens & Taxon \\
\hline 70 & $\begin{array}{l}\text { Massif of Śnieżnik, Bielice, thicket with Equisetum palustre } \\
50^{\circ} 15^{\prime} 59.2^{\prime \prime} \mathrm{N}, 17^{\circ} 00^{\prime} 06.1^{\prime \prime} \mathrm{E}\end{array}$ & 21 & $\mathrm{~F}$ \\
\hline \multicolumn{4}{|c|}{ Eastern Beskid Mts (Beskidy Wschodnie) } \\
\hline 71 & $\begin{array}{l}\text { Western Bieszczady Mts (Bieszczady Zachodnie) Wołosate, Przełęcz Beskid } \\
\text { (mountain pass), roadside ditch } \\
49^{\circ} 03^{\prime} 13.4^{\prime \prime N}, 22^{\circ} 42^{\prime} 21.8^{\prime \prime} \mathrm{E}\end{array}$ & 70 & $\begin{array}{c}\mathrm{D}, \mathrm{F}, \mathrm{V}, \mathrm{A}, \\
\mathrm{D} \times \mathrm{V}\end{array}$ \\
\hline 72 & $\begin{array}{l}\text { Western Bieszczady Mts, Wołosate, meadow in Szczawinka river valley } \\
49^{\circ} 03^{\prime} 16.5^{\prime \prime} \mathrm{N}, 22^{\circ} 41^{\prime} 30.7^{\prime \prime} \mathrm{E}\end{array}$ & 30 & $\mathrm{D}$ \\
\hline 73 & $\begin{array}{l}\text { Western Bieszczady Mts, Wołosate, forest roadside in Szczawinka valley } \\
49^{\circ} 03^{\prime} 15.2^{\prime \prime} \mathrm{N}, 22^{\circ} 41^{\prime} 29.1^{\prime \prime} \mathrm{E}\end{array}$ & 23 & F,D,A \\
\hline 74 & $\begin{array}{l}\text { Western Bieszczady Mts, Wołosate, meadow, N of village } \\
49^{\circ} 04^{\prime} 41.6^{\prime \prime} \mathrm{N}, 22^{\circ} 39^{\prime} 42.4^{\prime \prime} \mathrm{E}\end{array}$ & 15 & $\mathrm{~F}$ \\
\hline 75 & $\begin{array}{l}\text { Western Bieszczady Mts, Wołosate-Ustrzyki Górne, roadside ditch } \\
49^{\circ} 04^{\prime} 02.2^{\prime \prime} \mathrm{N}, 22^{\circ} 40^{\prime} 47.4^{\prime \prime} \mathrm{E}\end{array}$ & 19 & $\mathrm{~F}$ \\
\hline 76 & $\begin{array}{l}\text { Western Bieszczady Mts, Przełęcz Bukowska (mountain pass), along a stream } \\
49^{\circ} 03^{\prime} 13.92^{\prime \prime} \mathrm{N}, 22^{\circ} 46^{\prime} 22.56^{\prime \prime} \mathrm{E}\end{array}$ & 11 & $\mathrm{~F}$ \\
\hline 77 & $\begin{array}{l}\text { Western Bieszczady Mts, Przełęcz Bukowska, near tourist trail along a stream } \\
49^{\circ} 03^{\prime} 24.78^{\prime \prime} \mathrm{N}, 22^{\circ} 45^{\prime} 39.90^{\prime \prime} \mathrm{E}\end{array}$ & 15 & $\mathrm{~F}$ \\
\hline 78 & $\begin{array}{l}\text { Western Bieszczady Mts, Brzegi Górne, roadside ditch } \\
49^{\circ} 08^{\prime} 26.94^{\prime \prime} \mathrm{N}, 22^{\circ} 34^{\prime} 07.14^{\prime \prime} \mathrm{E}\end{array}$ & 16 & $\mathrm{~F}$ \\
\hline 79 & $\begin{array}{l}\text { Western Bieszczady Mts, Połonina Caryńska, depression with standing water } \\
49^{\circ} 08^{\prime} 22.92^{\prime \prime N}, 22^{\circ} 35^{\prime} 51.66^{\prime \prime E}\end{array}$ & 20 & $\mathrm{~F}$ \\
\hline 80 & $\begin{array}{l}\text { Western Bieszczady Mts, Wetlina, steep river bank } \\
49^{\circ} 09^{\prime} 35.2^{\prime \prime} \mathrm{N}, 22^{\circ} 27^{\prime} 36.4^{\prime \prime} \mathrm{E}\end{array}$ & 10 & $\mathrm{~F}$ \\
\hline
\end{tabular}

Explanations: A - C. $\times$ alsatica, $\mathrm{D}-$ C. demissa, $\mathrm{D} \times \mathrm{V}-$ C. demissa $\times$ C. viridula, $\mathrm{F}-$ C. flava s.s., $\mathrm{L}-$ C. lepidocarpa, $\mathrm{R}-$ C. $\times$ ruedtii, $\mathrm{Sch}-$ C. $\times$ schatzii, $\mathrm{V}-$ C. viridula 
Appendix 2. Sedges of the section Ceratocystis: (A) C. hostiana, Włochy, leg. H. Więcław 2010 (SZUB); (B) C. flava, Dąbrówno, leg. H. Więcław 2010 (SZUB); (C) C. lepidocarpa, Wałkowiska, leg. H. Więcław 2009 (SZUB); (D) C. demissa, Karpacz, leg. H. Więcław 2011 (SZUB); (E) C. viridula var. viridula, Grędziec, leg. H. Więcław 2009 (SZUB) (photograph by B. Kurnicki)

(A)

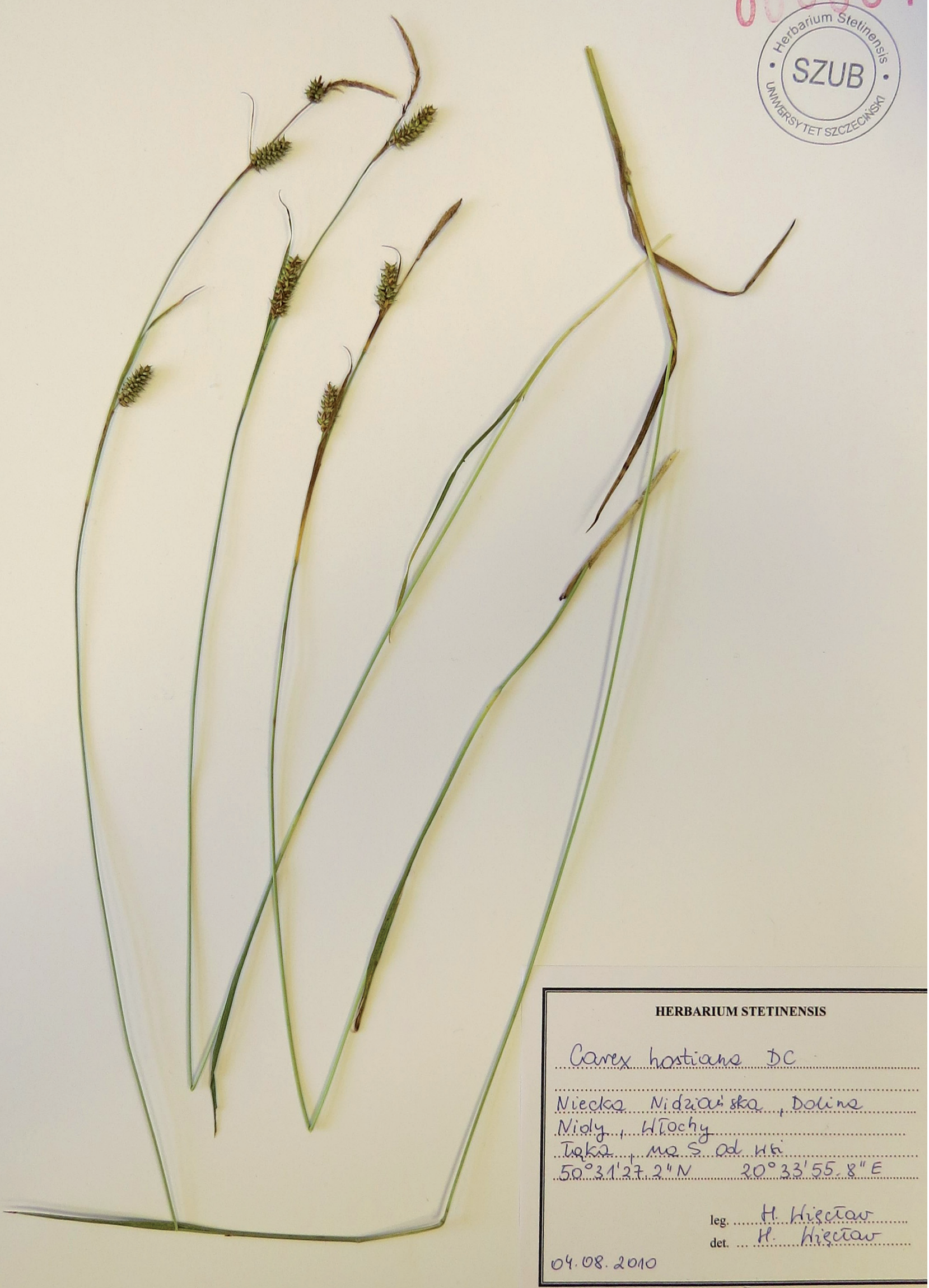




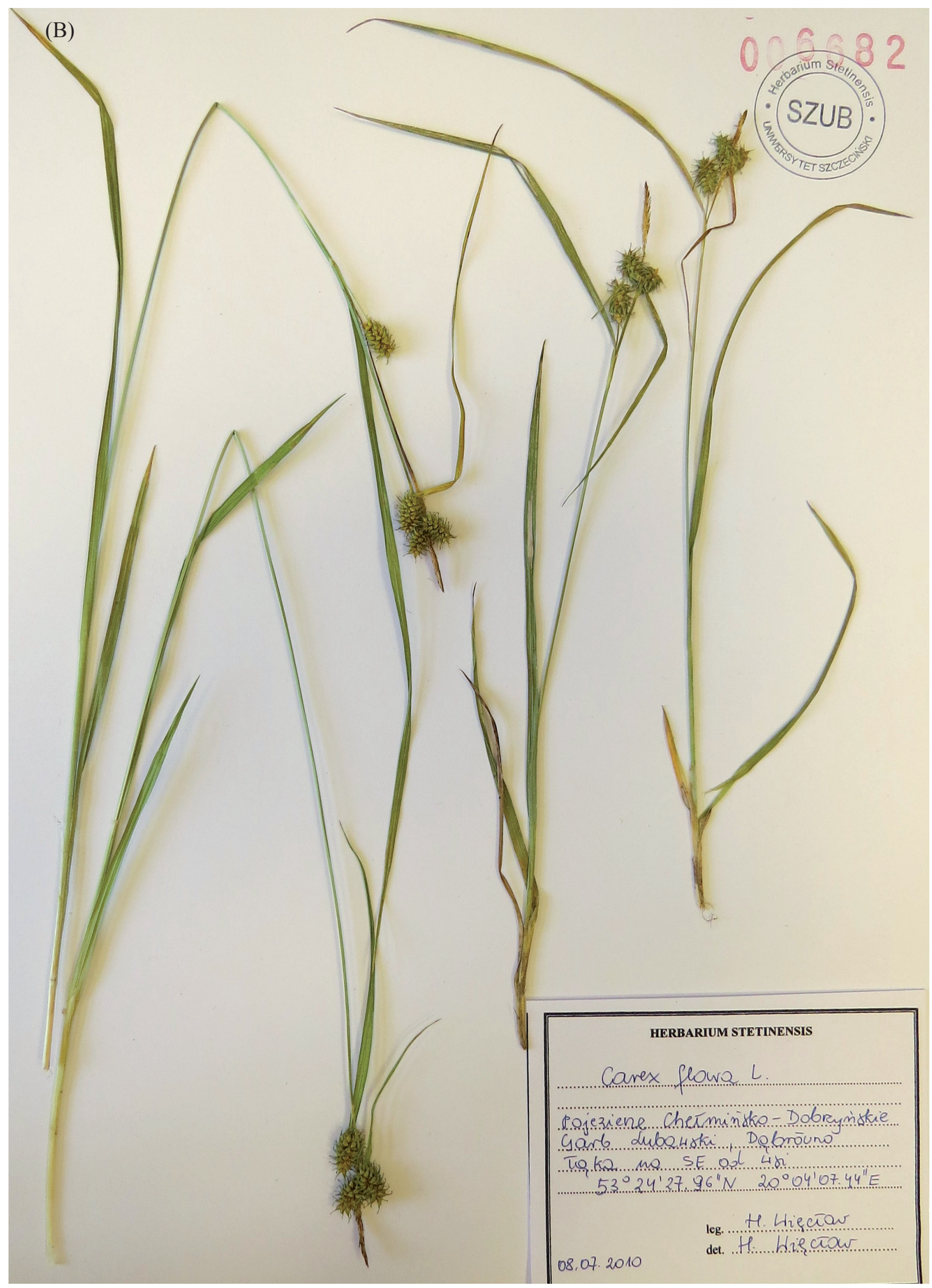




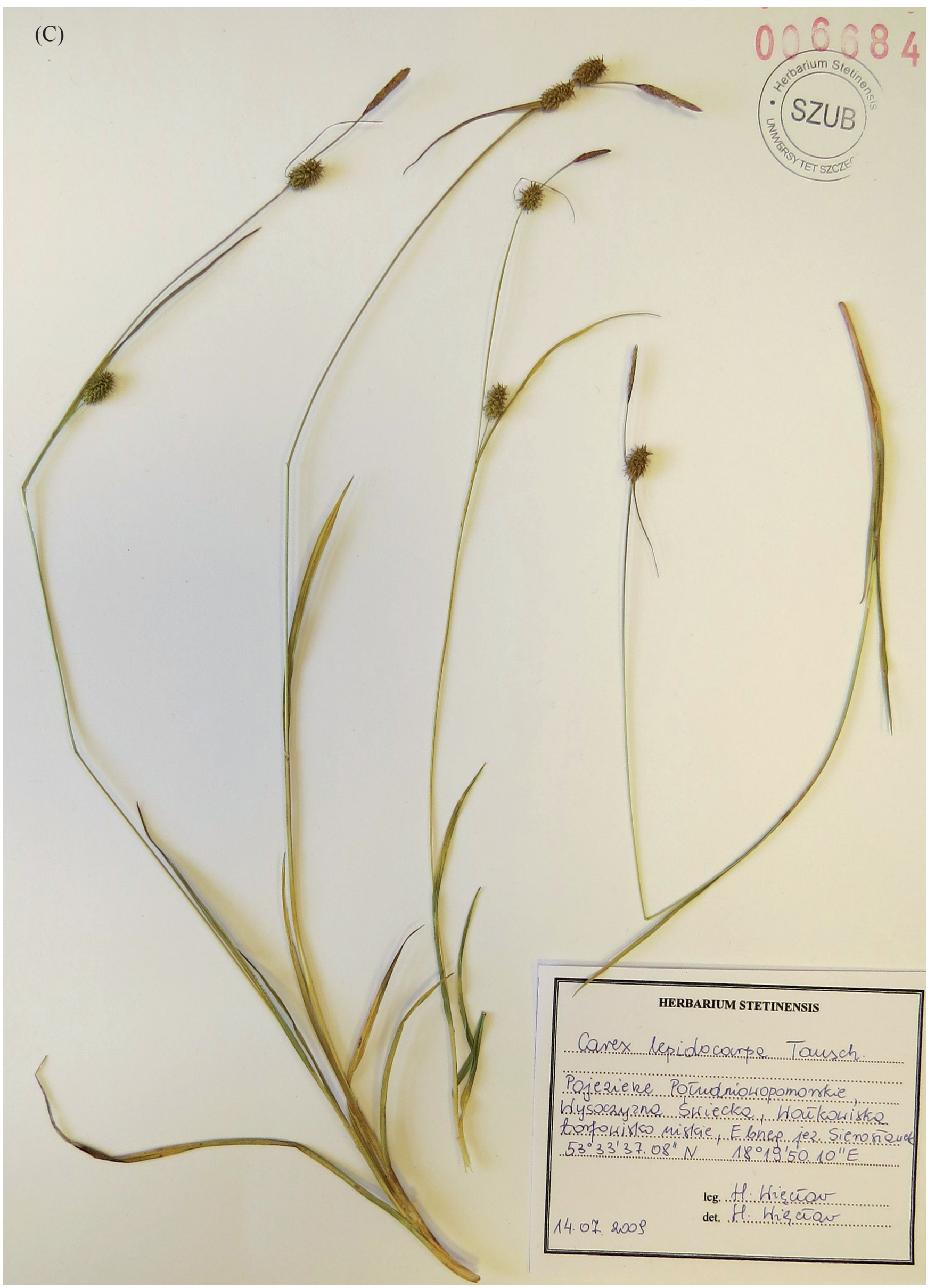




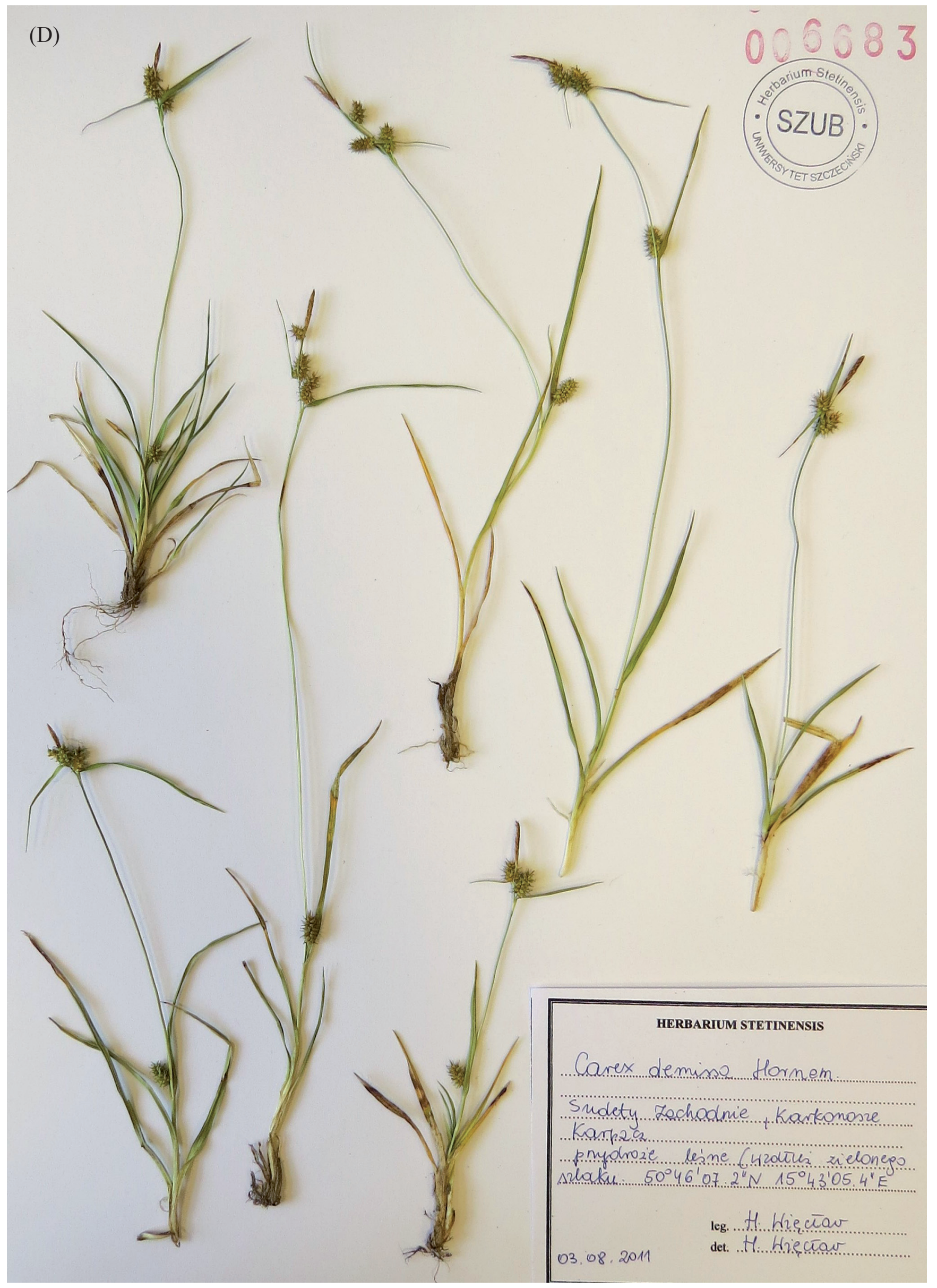




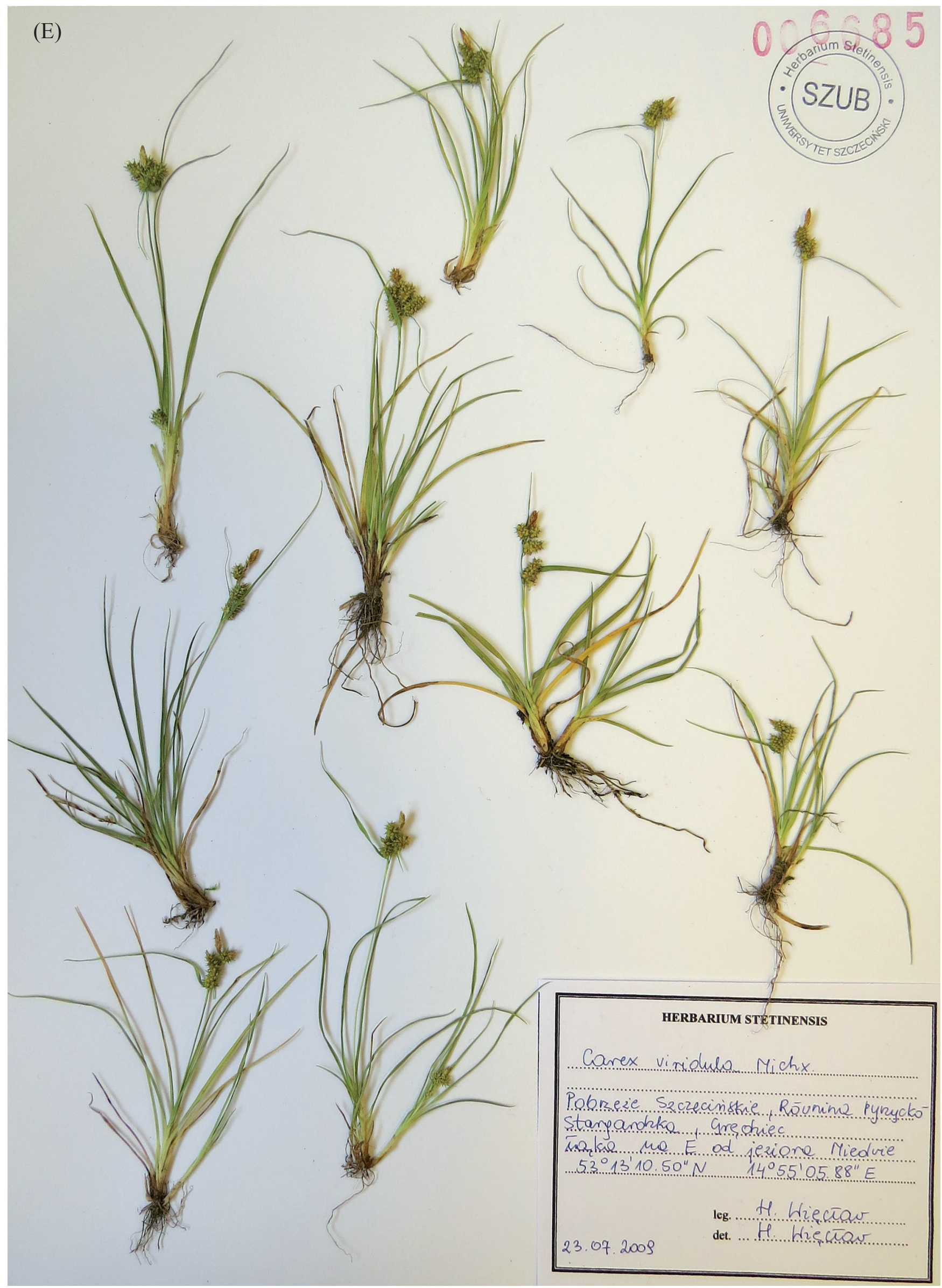


dodo

dotop

16tob 